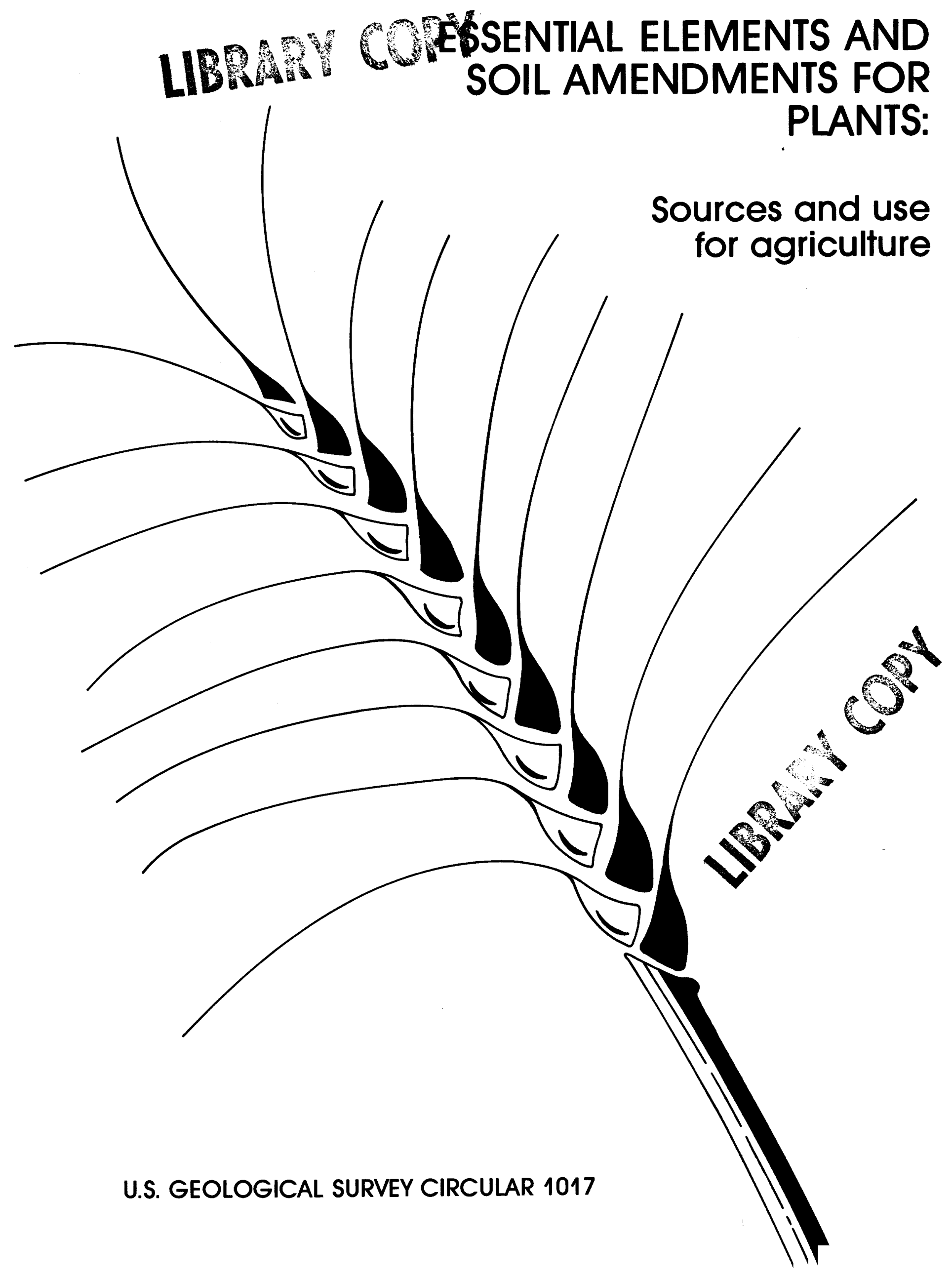


Cover art by Marty Simmons and Marilyn Billone 


\section{Essential Elements and Soil Amendments for Plants: Sources and Use for Agriculture}

By R. C. Severson and Hansford T. Shacklette

Geologic and incidental sources of elements essential for plant growth, and amendments used to improve physical properties of soils 


\section{DEPARTMENT OF THE INTERIOR \\ DONALD PAUL HODEL, Secretary}

U. S. GEOLOGICAL SURVEY

Dallas L. Peck, Director

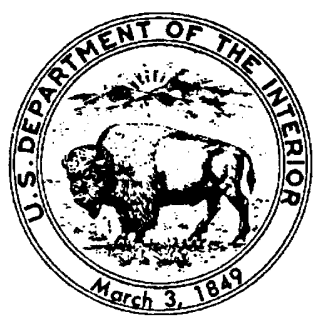

UNITED STATES GOVERNMENT PRINTING OFFICE: 1988

Free on application to

Books and Open-File Reports Section,

U.S. Geological Survey,

Box 25425, Building 810,

Federal Center,

Denver, CO 80225

\section{Library of Congress Cataloging in Publication Data}

Severson, R. C. (Ronald Charles), 1945-

Essential elements and soil amendments for plants.

(U.S. Geological Survey circular ; 1017)

"Geologic and incidental sources of elements essential for plant growth, and amendments used to improve physical properties of soils."

Supt. of Docs. no.: I 19.4/2:1017

1. Crops and soils. 2. Crops-Nutrition. 3. Soil

chemistry. 4. Geochemistry. 5. Fertilizers. 6. Soil amendments. I. Shack-

lette, Hansford T. II. Title. III. Series.

S596.7.S48 $1988 \quad 631.8 \quad 88-600362$ 


\title{
CONTENTS
}

\author{
Introductory statement 1 \\ Chemical elements essential for plants 2 \\ Introduction $\mathbf{2}$ \\ Major essential elements (macronutrients) 2 \\ Nitrogen 2 \\ Phosphorus 4 \\ Potassium 7 \\ Sulfur 11 \\ Calcium 14 \\ Magnesium 17 \\ Minor essential elements (micronutrients) $\quad 20$ \\ Boron 20 \\ Chlorine 22 \\ Copper 24 \\ Iron 27 \\ Manganese 29 \\ Molybdenum 32 \\ Zinc 34
}

Use of soil amendments to improve the physical properties of soil

Introduction 36

Mineral materials $\quad 37$

Clays 37

Zeolites 38

Volcanic materials 38

Sand 39

Organic materials 39

Peat 39

Humates $\quad 40$

Miscellaneous materials

Fly ash 40

Use to improve soil physical properties $\quad \mathbf{4 1}$

Use to improve soil chemical properties 41

Other materials 41

References cited $\mathbf{4 1}$

Selected references $\mathbf{4 2}$

Appendixes

1. Suggested terminology for soil amendments 44

2. Conversion factors used for English and metric units 45

3. Common plant names used in this report, with corresponding scientific names 45

4. Glossary of selected terms used in this report 46 



\title{
Essential Elements and Soil Amendments for Plants: Sources and Use for Agriculture
}

\author{
By R. C. Severson and Hansford T. Shacklette
}

\section{INTRODUCTORY STATEMENT}

The material in this report was derived from published sources, from unpublished data in our files, or from our experiences as soil scientist and botanist. We thought that a complete citation list for all data was both cumbersome and unnecessary in an outline of this type; therefore, only those references that represent large data sets are included in the text and are listed under "References Cited." The references we consulted frequently for facts and figures, but did not cite in the text, are listed under "Selected References." The selected references also include some compilations of information that we did not rely on heavily because they are tangential to the focus of this report but may be of value to the reader. We accept full responsibility for the discussions of plant nutrients or toxicants as being within our fields of competence. On the other hand, statements or inferences of nutritional and toxic effects of elements on man or domestic animals are taken directly from statements of animal nutritionists and are so identified by reference citations.

There are inconsistences in the order of expressing units of area and weight in the data given in this report. Agricultural reports prepared as practical guides tend to use the English system of weights and measures, rather than the metric system that is used most commonly in research reports. It is difficult for most American farmers to think in terms of "kilograms per hectare" rather than "bushels per acre" when considering crop yields; conversely, it is just as difficult for most scientists to visualize a bushel of corn weighing 60 pounds, or a bushel of oats weighing 34 pounds, to name but two of the vagaries in bushel weights. We have tried to first give the units in which the measurements were made as reported, followed by a conversion to the alternative system. We have also included metric-English conversion factors as Appendix 2.

Information in this report, for each element and amendment is arranged as follows:

ELEMENT

OCCURRENCE IN NATURAL MATERIALS

ABUNDANCE IN SELECTED ROCKS

ABUNDANCE IN "NATURAL" UNAMENDED SOILS

MINERALS

ORGANICS

ABUNDANCE IN SOILS

ABUNDANCE IN PLANTS

SOURCES FOR FERTILIZERS

GEOLOGIC OR OTHER PRINCIPAL SOURCES

INCIDENTAL GEOLOGIC OR OTHER SOURCES

ATMOSPHERIC

IRRIGATION WATER

MINERAL

ORGANIC

REACTIONS WITH SOIL CONSTITUENTS

FORMS USED BY PLANTS

FUNCTIONS IN PLANT METABOLISM

EXTENT OF USE

LOSSES FROM SOILS

LEACHING

EROSION

CROP REMOVAL

OTHER (VOLATILIZATION)

BALANCE SHEET

ADDITIONS

LOSSES

SOILS WHERE DEFICIENCIES ARE MOST COMMON 
Information for all major and minor elements is presented using a similar outline where possible.

An example of the outline format for amendments is illustrated as follows:

\section{AMENDMENT \\ SOURCES \\ MODE OF ACTION \\ EXTENT OF USE \\ POTENTIAL FOR USE}

We have also included a glossary of terms (Appendix 4) containing terms commonly used in soil science, botany, and agriculture, which will enable the reader to conveniently find the definition of an unfamiliar term.

We acknowledge with gratitude the assistance given by our colleagues in the U.S. Geological Survey in preparing this outline.

\section{CHEMICAL ELEMENTS ESSENTIAL FOR PLANTS}

\section{Introduction}

The background information provided on major and minor elements essential for plant growth may be useful in considering the application of geologic materials and processes to increase production and yield of food plants. This background information is not intended to be a detailed treatment of any aspect of fertilizer production or use, nor is it intended to include all materials and reactions involved in plant responses. Neither is it a guide to agricultural practices. Forms of fertilizers used and rates of application that are given only are examples selected to provide a general concept of kinds and quantities of fertilizers currently being utilized in the United States and other countries where agricultural technology is highly developed.

The manner in which the different elements are discussed is not entirely uniform but has been modified as we thought appropriate for the several classes of materials. For example, estimates of the annual production and use of the major nutritive elements and balance sheet estimates are available, and therefore could be given; whereas, estimates of the amounts of some minor elements used probably have not been made. Some elements used in fertilizers have a direct source in geologic materials, others are derived as byproducts of ore processing and other industrial operations or are manufactured from materials that are only indirectly related to geologic deposits. Our discussions reflect these differences.

\section{Major Essential Elements (Macronutrients)}

NITROGEN-(N)

\section{OCCURRENCE IN NATURAL MATERIALS} ABUNDANCE IN SELECTED ROCKS

From Turekian and Wedepohl (1961), in parts per million (ppm)

Ultrabasic, 6

Basaltic, 20

Granitic

High calcium, 20

Low calcium, 20

Syenites, 30

\section{ABUNDANCE IN “NATURAL” UNAMENDED SOILS \\ MINERALS}

There is no appreciable quantity of $\mathrm{N}$ in soil minerals.

ORGANICS

Most of the $\mathrm{N}$ in soils is held in decaying (humus) and living organic matter. "Representative" analysis of organic matter in soils: Humid regions, $80,000 \mathrm{lb} /$ acre-furrowslice $(89,600 \mathrm{~kg} / \mathrm{ha}$-furrow-slice) or $4 \%$. Arid regions, $65,000 \mathrm{lb} /$ acre-furrow-slice $(72,800$ $\mathrm{kg}$ /ha-furrow-slice) or $3.25 \%$. Range ordinarily expected, 0.40-10\%.

The $\mathrm{N}$ content of soils is almost entirely of atmospheric origin, most having been fixed as oxides or other compounds by nodule bacteria and by nonsymbiotic bacteria and algae. In uncultivated soils, the $\mathbf{N}$ content reaches equilibrium at a level ranging from about 6,600 $\mathrm{lb} / \mathrm{acre} / 40$ in. depth $(7,392 \mathrm{~kg} / \mathrm{ha} / 101.6 \mathrm{~cm}$ depth) in southern sandy soils to about 200,000 $\mathrm{lb} / \mathrm{acre} / 40 \mathrm{in}$. depth $(224,000 \mathrm{~kg} / \mathrm{ha} / 101.6 \mathrm{~cm}$ depth) in northern peats in which the $N$ is largely unavailable to plants. Total $\mathrm{N}$ in soils is a negative exponential function of temperature-for every $18^{\circ} \mathrm{F}\left(10^{\circ} \mathrm{C}\right)$ fall in mean temperature, the $\mathrm{N}$ content increases $2-3$ times because of the higher ratio of organic matter formation to decomposition.

\section{ABUNDANCE IN SOILS}

"Representative" analysis of agricultural soils (as $\left.\mathrm{N}_{2}\right), 4,000 \mathrm{lb} /$ acre-furrow-slice $(2,000,000 \mathrm{lb})$ or $4,480 \mathrm{~kg} / \mathrm{ha}$-furrow-slice (weighing 908,000 kg). In the U.S., $\mathrm{N}$ is highest in Brunizem or Borall soils of the prairie region of the Central States and declines eastward and westward in other soil groups. Some representative estimates (lb/acre/40 in. depth) follow: 
Nitrogen-Continued

ABUNDANCE IN "NATURAL"-Continued

Boralls (Brunizem) 16,000

$(17,920 \mathrm{~kg} / \mathrm{ha} / 101.6 \mathrm{~cm}$ depth), $3.2 \%$.

Ultisols (Red and Yellow Podzolic)...............4,000

$(4,480 \mathrm{~kg} / \mathrm{ha} / 101.6 \mathrm{~cm}$ depth $), 0.8 \%$.

Inceptisols or Mollisols (Brown Forest).......6,700

$(7,504 \mathrm{~kg} / \mathrm{ha} / 101.6 \mathrm{~cm}$ depth$), 1.3 \%$.

Ustols (Chestnut) 10,000

(11,200 kg/ha/101.6 cm depth), $2.0 \%$.

ABUNDANCE IN PLANTS

The $\mathrm{N}$ content of some crop plants is illustrated by the following examples:

Alfalfa hay, yield 4 tons/acre ( 9 metric tons/ha) $190 \mathrm{lb} / \mathrm{acre}(213 \mathrm{~kg} / \mathrm{ha}) \mathrm{N}$.

Cabbage, yield 15 tons/acre (33.3 metric tons/ ha) $-105 \mathrm{lb} /$ acre $(118 \mathrm{~kg} / \mathrm{ha}) \mathrm{N}$.

Corn grain, yield $130 \mathrm{bu} /$ acre $(113 \mathrm{hl} / \mathrm{ha})-120$

lb/acre (134 kg/ha) N.

Oats grain, yield $50 \mathrm{bu} /$ acre $(43.5 \mathrm{hl} / \mathrm{ha})-35$

$\mathrm{lb} / \mathrm{acre}(39 \mathrm{~kg} / \mathrm{ha}) \mathrm{N}$.

Potato tubers, yield $200 \mathrm{bu} / \mathrm{acre}(174 \mathrm{hl} / \mathrm{ha})-45$

$\mathrm{lb} /$ acre $(50 \mathrm{~kg} / \mathrm{ha}) \mathrm{N}$.

Sugar beet roots, yield 15 tons/acre (33.6 metric tons/ha) - $78 \mathrm{lb} /$ acre $(87 \mathrm{~kg} / \mathrm{ha}) \mathrm{N}$.

Wheat grains, yield $60 \mathrm{bu} / \mathrm{acre}(52 \mathrm{hl} / \mathrm{ha})-70$

lb/acre $(78 \mathrm{~kg} / \mathrm{ha}) \mathrm{N}$.

\section{SOURCES FOR FERTILIZER}

GEOLOGIC OR OTHER PRINCIPAL

\section{SOURCES}

Chilean nitrate $\left(96+\% \quad \mathrm{NaNO}_{3}\right)$. Insignificant amounts now used in the U.S.

Coal. Coking coal contains approximately $1-2 \%$ N. In coking, ammonia is driven off and reacted with sulfuric acid to produce ammonium sulfate. Yielding about $13 \mathrm{lb}$ ammonium sulfate per ton of coal $(6.5 \mathrm{~kg} /$ metric ton).

Cynamide process. Uses $\mathrm{CaCO}_{3}$, plus coke as a source of $\mathbf{N}$.

Synthetic ammonia. Presently the most important $\mathrm{N}$ fertilizer. $\mathrm{N}+\mathrm{H}$ heated with a catalyst (osmium + iron) forms ammonia. Methane is used as a source of $\mathrm{H}$; the source of $\mathrm{N}$ is coke, ammonia oxidation from nitric acid production, or fractional distillation of liquid air.

\section{INCIDENTAL GEOLOGIC OR OTHER SOURCES \\ ATMOSPHERIC}

Lightning discharges. Form oxides of $\mathrm{N}$ that are washed out of the atmosphere and deposited on the soil, adding $\mathrm{N}$ at the rate of $5-7 \mathrm{lb} / \mathrm{acre} / \mathrm{yr}$ $(5.6-7.8 \mathrm{~kg} / \mathrm{ha} / \mathrm{yr})$.
Nitrogen-Continued

INCIDENTAL GEOLOGIC-Continued

Industrial and vehicular emissions. Contain oxides of $\mathrm{N}$ that eventually are deposited on the soil. No estimates of amounts deposited or benefit to plants are available.

ORGANIC

Guano. Contains up to $13 \%$ N. The richest deposits have been exhausted.

Animal manures. Contain $0.60-1.0 \% \mathrm{~N}$, or approximately $10 \mathrm{lb} /$ ton (5 kg/metric ton). Used at a declining rate in modern agriculture due to cost of hauling and spreading, compared to high-test synthetic $\mathbf{N}$ fertilizers.

Green manures (high- $\mathrm{N}$ vegetation that is plowed under). Contains various amounts of $\mathrm{N}$, but its use is declining in large-scale agriculture.

Sewage sludge. Contains 5-6\% N. A limited, but useful, source if cost of application and presence of toxic elements do not preclude its use.

Miscellaneous organic residues. A wide variety of materials have limited, often local, use depending on availability and cost, including animal tankage $(5-10 \% \mathrm{~N})$, dried blood $(6-14 \% \mathrm{~N})$, fish scrap $(6-10 \% \mathrm{~N})$, cottonseed meal $(5-7 \% \mathrm{~N})$, tobacco stems $(1-2 \% \mathrm{~N})$, etc.

\section{REACTIONS WITH SOIL CONSTITUENTS}

Soil micro-organisms are the principal soil constituents involved in $\mathrm{N}$ reactions through their functions in the $\mathrm{N}$ cycle. Certain bacteria (Rhizobium sp.) that live in root nodules of legumes and certain other plants are able to utilize atmospheric $\mathrm{N}$ to build organic $\mathrm{N}$ compounds that are absorbed by higher plants. Some nonsymbiotic bacteria and algae in soil can perform the same function. When these organic materials undergo bacterial decomposition, the proteins are converted to amino acids that yield ammonium compounds by enzymatic hydrolysis brought about by soil bacteria, fungi,and ascomycetes. The ammonium ions can be absorbed by micro-organisms and higher plants and are also subject to oxidation by the nitrite and nitrate bacteria-the process of nitrification. These bacteria obtain energy from the process and the nitrates are a byproduct. The process also releases hydrogen ions, tending to lower the soil $\mathrm{pH}$. Nitrates are the most important form of $\mathrm{N}$ in the growth of the higher plants. But under certain soil 
Nitrogen-Continued

REACTIONS WITH SOIL-Continued conditions, particularly if poorly drained, nitrites and nitrates are reduced, liberating gaseous $\mathrm{N}$ which escapes into the atmosphere.

FORMS USED BY PLANTS

Nitrate $\left(\mathrm{NO}_{3}{ }^{-1}\right)$ ions, ammonium $\left(\mathrm{NH}_{4}{ }^{+1}\right)$ ions, urea $\left(\mathrm{NH}_{2} \mathrm{CONH}_{2}\right)$, water-soluble amino acids, and nucleic acid.

\section{FUNCTIONS IN PLANT METABOLISM}

An essential constituent of all living matter because it is part of the protein molecule. Many of the proteins are enzymes, others are nucleoproteins that are present in the chromosomes. The latter proteins serve as catalysts and as directors of metabolism. $\mathrm{N}$ is also an integral part of the chlorophyll molecule. The supply of $\mathrm{N}$ is related to carbohydrate utilization. If $\mathrm{N}$ supply in the tissues is low, carbohydrates accumulate; when the $\mathrm{N}$ supply becomes adequate, proteins are formed from the carbohydrates, more protoplasm is formed, and growth occurs. Therefore, the $\mathrm{N}$ and carbohydrate balance is critical in obtaining the plant product that is wanted-if succulent, rapid-growth plant tissues are wanted (as in salad vegetables), high $\mathbf{N}$ is maintained; if starch or sugar storage is wanted after sufficient growth has occurred (as in fruits, grains, roots, tubers), a lower $\mathrm{N}$ supply is desired for proper maturation of the produce.

\section{EXTENT OF USE}

Worldwide, 60 million metric tons (66.1 million English tons) of chemically-fixed nitrogen are used per year. Nitrogen fertilizers are used in all significant agricultural production because $\mathrm{N}$ is a factor for increasing plant growth on almost all soils. Application rates range widely, depending on type of crop, season, climate, nature of the soil, and so on. An example of nitrogen fertilizers applied in a "standard" rotation in relation to crops grown follows:

Corn crop, following

Legumes, or heavy manuring, $50-75 \mathrm{lb} /$ acre (56-84 kg/ha) N.

Soybeans, small grain, or 1 year of corn, $100-120 \mathrm{lb} /$ acre $(112-134 \mathrm{~kg} / \mathrm{ha}) \mathrm{N}$.

Corn following corn, continuously 100-150 lb/acre (112-168 kg/ha) N.

\section{LOSSES FROM SOIL}

Main losses are from leaching, crop removal, decay processes, and denitrification. A general estimate follows:

Removed in crops, $60 \mathrm{lb} /$ acre/yr $(67.2$ $\mathrm{kg} / \mathrm{ha} / \mathrm{yr}$ ).
Nitrogen-Continued

FORMS USED BY PLANTS-Continued

Leaching and volatilization, $70 \mathrm{lb} / \mathrm{acre} / \mathrm{yr}$

$(78.4 \mathrm{~kg} / \mathrm{ha} / \mathrm{yr})$.

\section{BALANCE SHEET}

A generalized sample of the estimated balance follows (no $\mathrm{N}$ fertilizers added):

ADDITIONS (lb/acre/yr)

Rainfall

$(7.8 \mathrm{~kg} / \mathrm{ha} / \mathrm{yr})$

Symbiotic bacteria 80

$(89.6 \mathrm{~kg} / \mathrm{ha} / \mathrm{yr})$

Nonsymbiotic organisms

$(28 \mathrm{~kg} / \mathrm{ha} / \mathrm{yr})$

Total $-25$

$(125 \mathrm{~kg} / \mathrm{ha} / \mathrm{yr})$

LOSSES (lb/acre/yr)

Crop removal (corn, 65 bu/acre

$(56.5 \mathrm{hl} / \mathrm{ha})$

$(67.2 \mathrm{~kg} / \mathrm{ha})$

Leaching, erosion, and

volatilization.

(168 kg/ha)

Total $\overline{210}$

$(235 \mathrm{~kg} / \mathrm{ha})$

Net Loss - $98 \mathrm{lb} / \mathrm{acre} / \mathrm{yr}(110 \mathrm{~kg} / \mathrm{ha} / \mathrm{yr})$

\section{SOILS WHERE DEFICIENCIES ARE MOST COMMON}

Soils of tropical and subtropical regions (rapid decomposition of organic matter).

Arid soils (minimal plant growth and biological activity).

Sandy soils (rapid leaching of $\mathrm{N}$ ).

\section{PHOSPHORUS-(P)}

OCCURRENCE IN NATURAL MATERIALS

\section{ABUNDANCE IN SELECTED ROCKS}

From Connor, Shacklette, and others (1975), in percent

Granite, Precambrian; Missouri 0.04

Rhyolite, Precambrian; Missouri .03

Sandstone

Sauk sequence; Western United States. .14

Roubidoux Formation; Missouri............ .01

Pope Megagroup; Kentucky...................... . .03

Pennsylvanian; Kentucky ........................... .03

Pennsylvanian; Missouri ............................ .07

Shale

Sauk sequence; Western United States. .08

Lower Mississippian; Kentucky ............... .03

Upper Mississippian; Kentucky ............... . .04

Mississippian; Missouri............................... . .05

Pennsylvanian; Kentucky ............................ .05

Pennsylvanian; Missouri ............................ .07 
Phosphorus-Continued

ABUNDANCE IN SELECTED-Continued

Limestone and dolomite

Sauk sequence; Western United States. .06

Sauk sequence; Missouri ........................... .01

Upper Ordovician; Kentucky.................... .11

Tippecanoe sequence; Missouri ......... <. 013

Lower Mississippian; Kentucky ............... . .02

Upper Missippippian; Kentucky.............. .01

Mississippian; Missouri.............................. .04

Pennsylvanian; Kentucky .......................... . .09

Pennsylvanian; Missouri ........................... .07

ABUNDANCE IN "NATURAL" UNAMENDED SOILS

MINERALS

The native phosphorus in soils originated largely from the disintegration and decomposition of rocks containing apatite, $\mathrm{Ca}_{10}\left(\mathrm{PO}_{4}\right)_{6}(\mathrm{~F}, \mathrm{Cl}, \mathrm{OH})_{2}$. It occurs as finely divided fluorapatite, hydroxyapatite, or chlorapatite, as iron or aluminum phosphates, in combination with the clay fraction, and in other combinations.

\section{ORGANICS}

In natural ecosystems, $P$ in an available form is largely held in a closed biological cycle as follows: Stable $P$ compounds in plants and animals $\rightarrow$ soluble $\mathbf{P}$ compounds produced by decomposition $\rightarrow$ absorption of the soluble $P$ compounds by plants $\rightarrow$ stable $\mathrm{P}$ compounds in plants and animals. Amounts lost from this cycle are relatively minor and are replaced by $\mathbf{P}$ from weathering of the soil minerals. In agroecosystems, the return of crop residues and animal manures can replace some of the $P$ that was removed from the soil by plants.

\section{ABUNDANCE IN SOILS}

"Representative" analysis of agricultural soils (as $\left.\mathrm{P}_{2} \mathrm{O}_{5}\right), 3,000 \mathrm{lb} / \mathrm{acre}$-furrow-slice $(2,000,000 \mathrm{lb}$ or $908,000 \mathrm{~kg}$ of soil) $(3,600 \mathrm{~kg} /$ ha-furrow-slice $)$.

In 1,140 samples (10 from each Missouri county) of the surface horizon of agricultural soils, $0.065 \%$, range $<0.01-0.61 \%$.

Average, all U.S. soils, 420 ppm (840 lb/acrefurrow-slice; $940 \mathrm{~kg} /$ ha-furrow-slice).

Average, Eastern U.S. soils, 324 ppm (648 lb/acre-furrow-slice; $726 \mathrm{~kg}$ /ha-furrow-slice).

Average, Western U.S. soils, 448 ppm (896 lb/acre-furrow-slice; $1,104 \mathrm{~kg} /$ ha-furrow-slice).

Distribution of abundances in U.S. surficial materials was given by Shacklette and Boerngen
Phosphorus-Continued

ABUNDANCE IN SOILS-Continued

(1984). Concentrations in many cultivated and uncultivated U.S. soils are given by Connor, Shacklette, and others (1975).

\section{ABUNDANCE IN PLANTS}

$P$ tends to be concentrated in the reproductive parts of plants (seeds, grain, fruits) or in other parts that are rich in protein. Examples of the $\mathbf{P}$ content of vegetables follow (geometric mean percent of ash weight):

Lima bean seeds, central Georgia, 6.7

Soybean seeds, unglaciated prairie, Missouri, 10

Corn grains, Missouri floodplains, 22

Sweet pepper fruits, Wisconsin, 1.9

Cabbage leaves, northern Georgia, 1.2

Onion bulbs, Wisconsin, 3.7

Potato tubers, Wisconsin, 2.2

$P$ concentration in woody tissue of trees and shrubs, as in herbaceous stems, tends to be low, as illustrated by the following examples (geometric mean percent of ash weight):

Black gum stems, northern Georgia, 1.2

Pignut hickory stems, Kentucky, 0.76

Red maple stems, central Georgia, 1.4

White oak stems, Missouri, 1.1

Examples of $P$ concentrations in forage, hay, and browse plants (geometric mean percent in ash):

Johnson grass, Missouri floodplain, 3.5

Big bluestem grass, Missouri glaciated prairie, 2.1

Kentucky bluegrass, Eastern U.S., 1.5

Western wheatgrass, Western U.S., 0.28

Alfalfa, Western U.S., 1.07

Mesquite, Southwestern U.S., 1.1

\section{SOURCES FOR FERTILIZERS \\ GEOLOGIC OR OTHER PRINCIPAL SOURCES}

Phosphate rock. The principal phosphate compound in all commercially important deposits is apatite, in which the phosphate is not readily available to plants. The phosphate rock is generally acidulated near its source to produce various forms of soluble phosphates; these acid phosphates constitute the common commercial P fertilizers.

\section{INCIDENTAL GEOLOGIC OR OTHER SOURCES}

MINERAL (Industrial)

Basic slag (see p. 15), $(\mathrm{CaO})_{5} \cdot \mathrm{P}_{2} \mathrm{O}_{5} \cdot \mathrm{SiO}_{2}$ $\left(15-20 \% \mathrm{P}_{2} \mathrm{O}_{5}\right)$

Bone black, $\mathrm{Ca}_{3}\left(\mathrm{PO}_{4}\right)_{2}\left(32-35 \% \mathrm{P}_{2} \mathrm{O}_{5}\right)$

Steamed bonemeal, $\mathrm{Ca}_{3}\left(\mathrm{PO}_{4}\right)_{2}\left(23-30 \% \mathrm{P}_{2} \mathrm{O}_{5}\right)$ 
Phosphorus-Continued

INCIDENTAL GEOLOGIC-Continued

ORGANICS

Guano, 9\% P. No longer an appreciable

fraction of total $P$ fertilizers used.

Sewage sludge, 2-3\% $\mathrm{P}_{2} \mathrm{O}_{5}$.

Animal tankage, 5-18\% $\mathrm{P}_{2} \mathrm{O}_{5}$.

Fish scrap, 5-8\% $\mathrm{P}_{2} \mathrm{O}_{5}$.

Bonemeal, 17-30\% $\mathrm{P}_{2} \mathrm{O}_{5}$.

\section{REACTIONS WITH SOIL CONSTITUENTS}

In acid mineral soils, the $\mathrm{H}_{2} \mathrm{PO}_{4}$ ions react with soluble $\mathrm{Al}, \mathrm{Fe}$, and $\mathrm{Mn}$ ions, forming hydroxyphosphates which are relatively insoluble and not readily available to plants. The $\mathrm{H}_{2} \mathrm{PO}_{4}$ ions may also react with insoluble hydroxides of these elements, forming insoluble compounds. In alkaline soils, phosphate is precipitated by $\mathrm{Ca}$ compounds, in most cases from $\mathrm{CaCO}_{3}$; the available $\mathrm{P}$ will react with both the $\mathrm{Ca}$ ion and its carbonate, forming relatively insoluble compounds. These compounds may be converted to even more insoluble compounds, such as oxy-, carbonate-, or even fluorapatite. This type of reaction may occur on heavily limed soils and is especially serious in Western U.S. soils because of the widespread presence of excess $\mathrm{CaCO}_{3} . \mathrm{P}$ may also become fixed by silicate clays and rendered relatively unavailable to plants.

$P$, in the organic compounds phytin and nucleic acid, can be utilized by plants as long as the compounds remain soluble. In acid soils, $\mathrm{Fe}$ and Al phytates are formed; in alkaline soils, Ca phytates; all are relatively insoluble. Nucleic acids are strongly adsorbed on clays, particularly montmorillonite, causing low $\mathbf{P}$ availability, especially in acid soils.

As a general rule, minimum fixation, therefore greater availability to plants, occurs if the soil $\mathrm{pH}$ is maintained at $\mathrm{pH}$ 6-7.

\section{FORMS USED BY PLANTS}

Plants absorb most of their $\mathrm{P}$ as the primary orthophosphate ion, $\mathrm{H}_{2} \mathrm{PO}_{4}{ }^{-1}$ but smaller amounts of the secondary orthophosphate ion, $\mathrm{HPO}_{4}{ }^{-2}$, are also absorbed. In addition, pyrophos-' phates and metaphosphates may possibly be absorbed by plant roots. Certain soluble organic phosphates, such as nucleic acid and phytin, are also absorbed, but because of their instability in the presence of an active microbial population, their importance as $\mathbf{P}$ sources for higher plants is limited.

FUNCTIONS IN PLANT METABOLISM

Phosphate or phosphoryl radicals in plant cells are transported to an acceptor group by a
Phosphorus-Continued

FORMS USED BY PLANTS-Continued

transfer reaction called phosphorylation; the activity of a compound is increased, and the number of chemical reactions possible in the plant system is enormously increased. Therefore, the $\mathbf{P}$ compounds are necessary for photosynthesis, interconversion of carbohydrates, glycolysis, amino-acid metabolism, fat metabolism, sulfur metabolism, biological oxidations, and many other life processes.

\section{EXTENT OF USE}

Worldwide estimate, more than 10 million metric tons (11.02 million English tons) per year applied as fertilizer. After nitrogen, the most common element for increasing agricultural production.

Example of annual application rate, $\mathrm{lb} / \mathrm{acre}$ (as $\mathrm{P}_{2} \mathrm{O}_{5}$ ):

Small grain, $40-80(44.8-89.6 \mathrm{~kg} / \mathrm{ha})$

Vegetable crops, $60-120$ (67.2-134.4 kg/ha)

Alfalfa, $160-320(179.2-353.4 \mathrm{~kg} / \mathrm{ha})$

Much larger amounts are often used for certain crops.

Large amounts, 1-5 tons/acres (2.2-11.2 metric tons/ha) of raw rock phosphate (12-35\% total P) may be used to build a reserve of slowly available $P$.

\section{LOSSES FROM SOILS}

LEACHING

Only minor amounts are lost by leaching, as the $\mathbf{P}$ in soils is mostly in relatively insoluble compounds. Principal losses follow:

\section{EROSION}

$P$ is found chiefly in the finest particles of the soil, which are most easily carried away from the surface by running water and by wind. Examples of erosion losses (lb/acre/yr) follow:

Continuous corn (clean cultivation), 18 (20.2 kg/ha/yr).

Continuous wheat, $9.4(10.5 \mathrm{~kg} / \mathrm{ha} / \mathrm{yr})$.

Continuous bluegrass, $0.2(0.22 \mathrm{~kg} / \mathrm{ha} / \mathrm{yr})$.

\section{CROP REMOVAL}

$P$ is concentrated in seeds (about $75 \%$ of the total $P$ in the plant). When the seeds (grain) are sold, therefore, about $75 \%$ of the $P$ that the plants obtained from the soil is lost from the farm. For example, a ton ( 0.9 metric ton) 
Phosphorus-Continued

FORMS USED BY PLANTS-Continued

of wheat contains about $8 \mathrm{lb}(3.6 \mathrm{~kg}) P$. If this grain is fed to meat animals on the farm, about $30 \%$ of the $P$ in the grain is absorbed by the animal, about $20 \%$ is lost in handling the manure, leaving about $50 \%$ that can be returned to the soil in manure. This return contrasts with the $20 \%$ that can be returned to the soil in straw or stover if the grain is sold from the farm. These methods of soil $P$ removal are illustrated by the following statement of Thorne (1930): "Seven 1,000bushel $[190,680 \mathrm{~kg}]$ carloads of corn or oats, or five such carloads of wheat, carry away as much phosphorus as is found in the plowed surface of an average acre of land, even though the stover and straw are conscientiously returned to the land $* * *$. Six carloads of fat cattle, or 14 carloads of fat hogs, may contain phosphorus equivalent to that contained in the surface 6 inches $[15.2$ $\mathrm{cm}$ ] of an acre, and the milk from a dairy of 130 average cows will carry off this quantity of phosphorus every year."

\section{BALANCE SHEET}

A generalized example of the estimated $P$ balance (lb/acre/yr) follows:

\section{ADDITIONS}

Fertilizers (minimal application)

$(2.12 \mathrm{~kg} / \mathrm{ha} / \mathrm{yr})$

Animal manure and bedding

$(1.7 \mathrm{~kg} / \mathrm{ha} / \mathrm{yr})$

Seeds sown.

$(0.22 \mathrm{~kg} / \mathrm{ha} / \mathrm{yr})$

Roots and unharvested parts .................... . .9

$(1.0 \mathrm{~kg} / \mathrm{ha} / \mathrm{yr})$

Total $\overline{4.5}$

$(5.04 \mathrm{~kg} / \mathrm{ha} / \mathrm{yr})$

\section{LOSSES}

Harvested crops

$(4.3 \mathrm{~kg} / \mathrm{ha} / \mathrm{yr})$

Grazing.

$(0.24 \mathrm{~kg} / \mathrm{ha} / \mathrm{yr})$

Erosion (cropland only). 10.6

$(11.8 \mathrm{~kg} / \mathrm{ha} / \mathrm{yr})$

Total loss $\overline{14.6}$

$(16.4 \mathrm{~kg} / \mathrm{ha} / \mathrm{yr})$

Net loss, 10.1 (11.4 kg/ha/yr)

(Note that in high-production farming, phosphate fertilizers are applied at a high rate, often resulting in a net gain of total $P$ in the soil.)
Phosphorus-Continued

\section{SOILS WHERE DEFICIENCIES ARE MOST COMMON}

Soils derived from parent material that is low in $\mathrm{P}$.

Highly weathered and eroded soils.

Soils with a long history of heavy cropping.

Calcareous and acid soils (low availability of P).

Peat and muck soils (low availability of P).

\section{POTASSIUM-(K)}

OCCURRENCE IN NATURAL MATERIALS

ABUNDANCE IN SELECTED ROCKS

From Connor, Shacklette, and others (1975), in percent:

Granite, Precambrian; Missour

4.30

Rhyolite, Precambrian; Missouri ............ 4.89

Sandstone

Sauk sequence; Western U.S................ 1.12

Roubidoux Formation; Missouri......... $\quad .14$

Pope Megagroup; Kentucky ................. . .55

Pennsylvanian; Kentucky....................... 1.12

Pennsylvanian; Missouri ........................ 1.08

Shale

Sauk sequence; Western U.S................ 5.94

Lower Mississippian; Kentucky............ 1.98

Upper Mississippian; Kentucky........... 2.41

Mississippian; Missouri .......................... 2.92

Pennsylvanian; Kentucky ....................... 2.53

Pennsylvanian; Missouri ......................... 2.83

Limestone and dolomite

Sauk sequence; Western U.S................ . .73

Sauk sequence; Missouri........................ . .44

Upper Ordovician; Kentucky................ . .48

Tippecanoe sequence; Missouri ........... . .24

Lower Mississippian; Kentucky............ $\quad .54$

Upper Missippippian; Kentucky........... $\quad .34$

Pennsylvanian; Kentucky ........................ $\quad .84$

Pennsylvanian; Missouri .......................... . .24

\section{ABUNDANCE IN “NATURAL” UNAMENDED SOILS}

MINERALS

Feldspars (sanidine, orthoclase, microcline), muscovite $\mathrm{H}_{2} \mathrm{KAl}_{3}\left(\mathrm{SiO}_{4}\right)_{3}$, biotite $(\mathrm{H}, \mathrm{K})_{2}(\mathrm{Mg}, \mathrm{Fe})_{2} \mathrm{Al}_{2}\left(\mathrm{SiO}_{4}\right)_{3}$, and illite. $\mathrm{K}$ is also held as an adsorbed cation on some other minerals. 
Potassium-Continued

ABUNDANCE IN "NATURAL"-Continued ORGANICS

K constitutes $25 \%$ or more of plant ash, being exceeded as an element in plants only by the silica content in ash of silica-accumulating plants. In natural ecosystems, most of the total $\mathrm{K}$ is in unavailable compounds in the soil-the lesser soluble amounts are held in a loose cycle as follows: $K$ in soil solution $\rightarrow K$ in plants (in the ionic form, or as charged particles on colloidal surfaces, not part of a specific compound) $\rightarrow K$ in animals (most is secreted in urine) $\rightarrow$ soluble $K$ compounds in the soil solution from animal excretions and decomposition of plants and animals. The $\mathrm{K}$ in the soil solution that is lost by the slight leaching and erosion is replaced through extraction of $\mathrm{K}$ by plant roots from primary minerals and from the $K$ fixed on clay structures. In agroecosystems, the return of plant residues and manures replaces some of the $\mathrm{K}$ that was removed from the soil by cropping.

\section{ABUNDANCE IN SOILS}

"Representative" analysis of agricultural soils: Humid region soils, $1.70 \%$ or $34,000 \mathrm{lb} / \mathrm{acre}$ furrow-slice $\quad(48,000 \quad \mathrm{~kg} / \mathrm{ha}$-furrow-slice $)$ $(2,000,000 \mathrm{lb}$, or $908,000 \mathrm{~kg})$; arid region soils, $2 \%$ or $40,000 \mathrm{lb} /$ acre-furrow-slice $(44,800 \mathrm{~kg} / \mathrm{ha}$ furrow-slice).

Ranges ordinarily expected, $0.17-3.30 \%$.

In 1,140 samples (10 from each Missouri county) of the surface horizon of agricultural soils, $1.4 \%$, range $0.33-3.7 \%$.

Average, all U.S. soils, $1.2 \%$

Average, Eastern U.S. soils, $0.74 \%$

Average, Western U.S. soils, $1.7 \%$

Distribution of concentrations in U.S. surficial materials mapped in USGS Professional Paper 1270. Concentrations in a wide variety of cultivated and uncultivated U.S. soils were given by Connor, Shacklette, and others (1975).

\section{ABUNDANCE IN PLANTS}

Examples of the $\mathrm{K}$ concentration in vegetables and crop plants (geometric mean percent in ash) follow:

Lima bean seeds, central Georgia, 35

Soybean seeds, unglaciated prairie, Missouri, 39
Potassium-Continued

ABUNDANCE IN PLANTS-Continued

Corn grains, Missouri floodplain, 29

Snap bean pods (fruit), central Georgia, 33

Cabbage leaves, northern Georgia, 18

$\mathrm{K}$ concentrations in stems and leaves of woody plants tend to be about half that in seeds and fruits of crop plants; moreover, leaves usually have higher levels than do stems. Examples (geometric mean percent in ash) follow:

Black gum stems, central Georgia, 11

Black gum leaves, central Georgia, 16

Red maple stems, central Georgia, 11

Red maple leaves, central Georgia, 12

White oak stems, Missouri, 5.1

Examples of $\mathrm{K}$ concentrations in forage, hay, and browse plants (geometric mean percent in ash) follow:

Johnson grass, Missouri floodplain, 16.0

Big bluestem, Missouri glaciated prairie, 16.0

Western wheatgrass, Western U.S., 11.9

Alfalfa, Western U.S., 17.8

Mesquite, Southwestern U.S., 10.8

Concentrations of $\mathrm{K}$ in a wide variety of cultivated and native plants were given by Connor, Shacklette, and others (1975).

A large number of species (mostly trees and shrubs) that were sampled at 910 widely distributed localities in the U.S. averaged $13 \% \mathrm{~K}$ in ash.

\section{SOURCES FOR FERTILIZERS \\ GEOLOGIC OR OTHER PRINCIPAL SOURCES}

Sylvite, $\mathrm{KCl}, 52.3 \% \mathrm{~K}$.

Langbeinite, $\mathrm{KCl} \cdot 2 \mathrm{MgSO}_{4}, 18.8 \% \mathrm{~K}$.

Sylvinite, $\mathrm{KCl} \cdot \mathrm{NaCl}$ mixture.

Carnallite, $\mathrm{KCl} \cdot \mathrm{MgCl}_{2} \cdot 6 \mathrm{H}_{2} \mathrm{O}, 14.1 \% \mathrm{~K}$.

Kainite, $\mathrm{MgSO}_{4} \mathrm{KCl} \cdot 3 \mathrm{H}_{2} \mathrm{O}, 15.7 \% \mathrm{~K}$. Niter, $\mathrm{KNO}_{3}$, $38.6 \% \mathrm{~K}$.

Polyhalite, $\mathrm{K}_{2} \mathrm{SO}_{4} \mathrm{MgSO}_{4} \cdot 2 \mathrm{CaSO}_{4} \cdot 2 \mathrm{H}_{2} \mathrm{O}$, $13.5 \% \mathrm{~K}$. 
Potassium - Continued

INCIDENTAL GEOLOGIC OR OTHER SOURCES

\section{MINERAL}

Glauconite, $5 \%$ as $\mathrm{K}_{2} \mathrm{O}$.

Sea water, 1.6 million tons $\mathrm{mi}^{3}$ (2.87 million metric tons $/ \mathrm{km}^{3}$ ). Research on use of this source has made little progress, although Norwegian workers have reported some success.

Lake brines. Searles Lake, California, brines are reported to contain $4.7 \% \mathrm{~K}$ as $\mathrm{KCl}$.

\section{ORGANIC}

Seaweed, kelp, $30 \%$ in ash as $\mathrm{K}_{2} \mathrm{O}$. Tobacco byproducts, $6-10 \%$ in ash as $\mathrm{K}_{2} \mathrm{O}$. Water hyacinth (an aquatic weed), $4 \%$ in ash. Wood ashes, $6 \%$.

\section{REACTION WITH SOIL CONSTITUENTS}

The total amount of $\mathrm{K}$ in soils generally is high compared to the content of $\mathrm{N}$ and $\mathrm{P}$, but most exists in the unavailable form. When $\mathrm{K}$ as an available (soluble) salt is applied to soils, the extent of fixation as insoluble compounds is almost always directly proportional to the content of colloidal matter in the soil, being greatest in clays and clay loams and least in sands and sandy loams. For this reason, smaller amounts can be applied to sandy soils to satisfactorily increase crop yield than are necessary for the same effect on clay soils, but at the same time leaching losses are greatest in the sandy soils. The latter soils should have the fertilizer applied at a time when the crop plants can absorb it immediately to prevent excessive loss through leaching. In "heavier" soils it is possible to build a $\mathrm{K}$ reservethe fixed $\mathrm{K}$ can move slowly (become soluble) at a rate determined by the nature of the colloidal complex. Applications of lime increase $\mathrm{K}$ fixation in some soils. This effect may be desirable on sandy soils in that leaching losses are reduced. In other soils, $\mathrm{K}$ deficiency for plants may be caused by excess calcium carbonate. Of the total $\mathrm{K}$ in soils, $90-98 \%$ is estimated to be relatively unavailable, being contained mostly in the feldspars and micas which are quite resistant to weathering. They are thought to supply relatively small quantities of $\mathrm{K}$ during a single growing season, but their accumulative contribution from year to year to the total available soil $\mathrm{K}$ is of considerable importance. For this reason, the idea that each pound of $\mathrm{K}$ removed by plants or
Potassium-Continued

REACTIONS WITH SOIL-Continued

through leaching must be returned in fertilizers may not always be correct.

FORMS USED BY PLANTS

$\mathrm{K}$ is absorbed by plants as the ion $\mathrm{K}^{+1}$. Compounds which provide the $\mathrm{K}$ in a readily available form are $\mathrm{KNO}_{3}, \mathrm{~K}_{3} \mathrm{PO}_{4}, \mathrm{KCl}, \mathrm{K}_{2} \mathrm{SO}_{4}$, and $\mathrm{K}_{2} \mathrm{CO}_{3}$.

\section{FUNCTIONS IN PLANT METABOLISM}

$\mathrm{K}$ apparently does not form an integral part of such plant components as protoplasm, fats, and cellulose; its function appears to be catalytic in nature. Still, it is essential to many physiological functions in plants, including carbohydrate metabolism and breakdown and translocation of starch, nitrogen metabolism and synthesis of protein, regulation of the activities of various essential mineral elements, neutralization of physiologically important organic acids, activation of various enzymes, growth of meristematic tissue, and adjustment of stomatal movement and water relations.

An important effect of $\mathrm{K}$ deficiency relates to its function in protein synthesis. This deficiency may result in a buildup of amide $\mathrm{N}$ and $\mathrm{a}$ reduced conversion to protein. This results further in an accumulation of nonprotein $\mathrm{N}$, which is easily deaminated in the rumen of sheep and other ruminants. The rapid release of large amount of $\mathrm{NH}_{3}$ in the rumen may be very injurious to the animal (Tisdale and Nelson, 1967, p. 83-84).

Sodium can replace $\mathrm{K}$ as a nutrient in certain plants. For example, Na can replace $80 \%$ of the $\mathrm{K}$ requirement of sugar beets, but almost none of the $\mathrm{K}$ requirement of potatoes.

\section{EXTENT OF USE}

Estimated worldwide use, 15 million metric tons/yr (16.5 million English tons/yr) as manufactured fertilizers. In modern agriculture, high yields promoted by the increased use of $\mathrm{N}$ and $\mathrm{P}$ have greatly increased the draft on soil $\mathrm{K}$ which, coupled with the considerable leaching loss of $\mathrm{K}$, has increased the demand for $\mathrm{K}$ to the point that its usage in commercial fertilizers now exceeds that of nitrogen and rivals that of phosphorus.

An example of recommended $\mathrm{K}$ applications to soils low in $\mathrm{K}$ for a typical crop rotation (lbs/ acre) follow:

Broadcast before first plowdown, 208 (233 $\mathrm{kg} / \mathrm{ha}$ ) 
Potassium-Continued

FORMS USED BY PLANTS-Continued

Corn, first year, 0

Corn, second year, $20(22.4 \mathrm{~kg} / \mathrm{ha})$

Soybeans, 0

Wheat, 17 (19 kg/ha)

Examples of annual application rate as $\mathrm{K}_{2} \mathrm{O}$ (lb/acre) follow:

Potatoes (North Carolina), 80-100 (89.6-112 kg/ha).

Cotton (Southeastern U.S.), 175-200

(196-224 kg/ha).

Alfalfa, corn, cereals, 160 (179 kg/ha).

\section{LOSSES FROM SOILS}

LEACHING

Losses by leaching are dependent on fixation of soluble $K$ in the soil. Fixed $K$ slowly becomes soluble. In sandy soils, $\mathrm{K}$ may move down to the ground water; while in clay or silt soils, the movement is largely restricted to the upper 4-6 inches $(10.2-15.2 \mathrm{~cm})$ of soil.

Silty clay loam, Ithaca, N.Y., lb/acre/yr (10-yr averages)

Bare soil, 87 (97.4 kg/ha/yr)

Rotated cropland, $69(77.3 \mathrm{~kg} / \mathrm{ha} / \mathrm{yr})$

Continuous grass, 75 (kg/ha/yr)

\section{EROSION}

Because most of the available $K$ is in the upper soil horizons, erosion of surface soil can cause severe $\mathbf{K}$ deficiencies for crops. However, most of the total $\mathrm{K}$ in soils is in the lower horizons, so erosional loss of total $\mathrm{K}$ is not as great as that of total N and P. An example of $\mathrm{K}$ losses by erosion (lb/acre/yr) in Missouri follows:

Continuous corn cultivation, 605 (677.6 $\mathrm{kg} / \mathrm{ha} / \mathrm{yr}$ )

Rotation; corn, wheat, clover, 214 (239.7 $\mathrm{kg} / \mathrm{ha} / \mathrm{yr}$ )

\section{CROP REMOVAL}

The amount of $\mathrm{K}$ lost from this cause is, under many conditions, the greatest loss. Because $K$ is not combined in organic compounds but moves freely through plant tissues, there is no limit fixed by metabolic requirements on the amounts absorbed. Consequently, if the soil solution contains abundant $\mathrm{K}$, plants may absorb much more $\mathrm{K}$ than is necessary for its catalytic functionsthe so-called luxury consumption of $\mathrm{K}$. This excessive use of $\mathrm{K}$ can significantly increase the amount of $\mathrm{K}$ lost from the soil by crop removal. Amounts of $\mathrm{K}$ lost by crop removal (lb/acre/yr) follow:
Potassium-Continued

FORMS USED BY PLANTS-Continued

Corn, yield $100 \mathrm{bu} /$ acre $(87 \mathrm{hl} / \mathrm{ha}), 25$ (28

$\mathrm{kg} / \mathrm{ha} / \mathrm{yr}$ ).

Wheat, yield $50 \mathrm{bu} /$ acre (44 hl/ha), 12 $(13.4 \mathrm{~kg} / \mathrm{ha} / \mathrm{yr})$.

Alfalfa, yield 10 tons/acre (22.4 metric tons/ha), 100 (112 kg/ha/yr).

Beets, yield 121/2 tons/acre (10.9 metric tons/ha), 125 (140 kg/ha/yr).

The following examples illustrate the loss of $\mathrm{K}$ by plant removal at a larger scale:

Ecuador exports 1 million metric tons (0.44 million English tons) of bananas annually, containing 4,600,000 kg $(10,143,000 \mathrm{lb}) \quad \mathrm{K}$. Hawaii exports $2,000,000 \mathrm{~kg}(4,410,000 \mathrm{lb})$ of $\mathrm{K}$ annually in its pineapple crop.

\section{BALANCE SHEET}

\section{ADDITIONS}

Except for the addition of small amounts of $\mathrm{K}$ by weathering of soil minerals, there is no addition of $\mathrm{K}$ by natural processes.

\section{LOSSES}

The loss or gain in $\mathrm{K}$ under the widely ranging cultivation practices, crops grown, and soil types cannot be easily generalized. However, the following estimate may suggest the magnitude of this loss (crop residues left in the field; loss in lb/acre/yr):

Wheat, yield $50 \mathrm{bu} / \mathrm{acre}$ 12 (43.5 hl/ha) (13.4 kg/ha/yr)

Leaching. 58 $(64.9 \mathrm{~kg} / \mathrm{ha} / \mathrm{yr})$

Erosion 200 $(224 \mathrm{~kg} / \mathrm{ha} / \mathrm{yr})$

Total Loss $\overline{270}$ $(302.3 \mathrm{~kg} / \mathrm{ha} / \mathrm{yr})$

The total loss represents the approximate amount that must be added annually under the above conditions if fertility is to be maintained. Even if leaching and erosion are eliminated from the losses and all crop residue is left on the field, for every ton (0.9 metric ton) of wheat produced and shipped from the farm, about $8 \mathrm{lb}(3.6 \mathrm{~kg})$ of the available soil $\mathrm{K}$ is lost. If corn is grown and fed to meat animals (wheat is not commonly a livestock feed), the manure (especially the urine) is returned to the soil, and the animals sold from the farm, for every ton ( 0.9 metric ton) of corn produced, probably only about $2-3 \mathrm{lb}(0.9-1.4 \mathrm{~kg})$ of available $\mathrm{K}$ leaves the farm. 
Potassium-Continued

\section{SOILS WHERE DEFICIENCIES ARE MOST COMMON}

Light sandy soils which are easily leached (low total amount).

Organic soils such as peat and muck (low availability).

Soils that have been heavily cropped, leached, and eroded.

Highly leached soils of tropical regions are universally low in available $\mathbf{K}$.

\section{SULFUR-(S)}

OCCURRENCE IN NATURAL MATERIALS

\section{ABUNDANCE IN SELECTED ROCKS}

From Turekian and Wedepohl (1961), in parts per million (ppm)

"Igneous" rocks, 300

Sedimentary rocks

Shales, 2,400

Sandstones, 240

Carbonates, 1,200

From E. R. Cressman (oral commun., 1974), in percent

Phosphatic limestone, Ordovician; Kentucky

16 samples, average 0.44 ; range $0.15-0.60$

9 samples, average 0.23 ; range $0.15-0.89$

\section{ABUNDANCE IN “NATURAL" UNAMENDED} SOILS

\section{MINERALS}

Sulfates of $\mathrm{Ca}, \mathrm{Mg}, \mathrm{N}$, and $\mathrm{K}$. These soil minerals are most abundant in arid regions.

\section{ORGANICS}

Much of the $S$ of humid-region soils is in the organic form. S occurs in tissue of all plants as organic S (a component of the protein molecule), the amount ranging widely as a genetic trait at the species or family level. In addition, plants commonly contain readily mobile sulfate sulfur in the vascular system in amounts, for many species, greatly in excess of metabolic requirements and which are controlled by the concentration of $S$ in the soil. The sulfur in plant roots is a normal component of soil chemistry, and eventually is recycled into new living plants, or leaves the system through leaching, erosion, or volatilization through bacterial action.

\section{ABUNDANCE IN SOILS}

"Representative" analysis, agricultural soils, in lb/acre-furrow-slice $(2,000,000 \mathrm{lb} ; 908,000 \mathrm{~kg})$ Humid regions, 800 (896 kg/ha-furrow-slice); arid regions, 1,600 (1,792 kg/ha-furrow-slice). Range
Potassium-Continued

ABUNDANCE IN SOILS-Continued

in percentages that may be ordinarily expected, $0.01-0.20 \%$.

\section{ABUNDANCE IN PLANTS}

The $S$ in plant tissues occurs in two formssulfate $S$ and organic $S$. The following examples of concentrations are for total S (percent, dry weight basis):

Corn grains, 0.24

Wheat grains, 0.18

Barley grains, 0.14

Rice grains, $0.124-0.128$

Alfalfa hay, 0.41

Clover hay, 0.25

Soybean hay, 0.23

$\mathrm{S}$ is known to be concentrated in many species of the mustard family (cabbage, cauliflower, mustard, turnip, and radish, for example), but quantitative data are not available.

\section{SOURCES FOR FERTILIZERS \\ GEOLOGIC OR OTHER PRINCIPAL SOURCES}

Elemental S

Pyrite, $\mathrm{FeS}_{2}$

Other sulfide minerals (as refining byproducts)

Gypsum, $\mathrm{CaSO}_{4} \cdot 2 \mathrm{H}_{2} \mathrm{O}$

Fossil fuels (removed in refining petroleum and natural gas; removed from stack emissions in pollution control)

\section{INCIDENTAL GEOLOGIC OR OTHER SOURCES \\ ATMOSPHERIC}

Atmospheric $\mathrm{S}$, derived from industrial emissions, ocean spray, and as $\mathrm{H}_{2} \mathrm{~S}$ and $\mathrm{SO}_{2}$ from swamps and marshes, can be absorbed directly by plants, or indirectly from soil if washed out of the air by precipitation as $\mathrm{H}_{2} \mathrm{SO}_{3}$. Plants can absorb 25-35\% of their S requirement directly from the air. The total atmospheric S added to soil is largely controlled by distance from sources of industrial emissions, and ranges from 1-10 lb/acre/yr (1.12-11.2 kg/ha/yr). Atmospheric S, as $\mathrm{SO}_{2}$, also enters the soil by direct gaseous diffusion. Grey and Jenson (1972) reported that in the Salt Lake City, Utah, area bacteriogenic S released by anaerobes from mud may rival industrial $S$ emissions as a source of atmospheric $S$ compounds. Buckman and Brady (1969, p. 463-464) wrote, "The recognition that clean air is a laudable goal will necessitate finding alternative means of supplying sulfur for plant growth." 
Sulfur-Continued

INCIDENTAL GEOLOGIC-Continued

ORGANIC

Plant residues

The return of plant residue to the soil constitutes a significant addition of $S$ that is readily available to plants. The amount returned varies greatly among residues from different plants, and no quantitative data are available.

\section{Animal manures}

A useful source of $S$, among other major nutrient elements, the $S$ content ranges widely according to kinds of animals, manure storage, and application practices. General estimates of the amounts of $S$ in different manures follow (kg/metric ton, fresh material):

Dairy cattle, 0.5 (1.2 lb/English ton)

Fattening cattle, 0.85 ( $2.07 \mathrm{lb} /$ English ton $)$

Hogs, 1.35 (3.28 lb/English ton)

Horses, 0.7 (1.7 lb/English ton)

Sheep, 0.9 (2.2 lb/English ton)

\section{Sewage sludge}

Sewage contains significant amounts of $S$, but because of the obnoxious odor of $\mathrm{H}_{2} \mathrm{~S}$ that is liberated if applied raw to fields, storage and drying are used to reduce the $S$ content through bacterial action. Quantitative data on $\mathrm{S}$ in finished sewage sludge are not available.

\section{REACTIONS WITH SOIL CONSTITUENTS}

Sulfate is the end product of all S fertilizers added to soils. In arid region soils, it forms sparingly soluble salts with some cations present. In humid regions, sulfate is commonly leached from the upper soil horizons and either accumulates in lower horizons or is leached from the soil. Factors enhancing adsorption of sulfate on soil constituents are large amounts of clay, especially kaolin; presence of hydrous $\mathrm{Fe}$ and $\mathrm{Al}$ oxides; low soil $\mathrm{pH}$; high sulfate concentration; impeded movement of soil solution to increase period of contact; presence of weakly held anions such as nitrate and chloride; and occurrence of cations that enhance sulfate adsorption. Liming and phosphate fertilization both reduce sulfate adsorption. Adsorbed sulfate has lower availability than soluble sulfate but is an important source for some plants and helps conserve $S$ fertilizers and native soil $S$ by reducing leaching losses.
Sulfur-Continued

\section{FORMS USED BY PLANTS}

Sulfate sulfur is probably the only form absorbed by plant roots. Some compounds in which the $\mathrm{S}$ is readily available to plants are $\mathrm{K}_{2} \mathrm{SO}_{4}, \mathrm{CaSO}_{4}$, $\mathrm{Na}_{2} \mathrm{SO}_{4}$, and $\mathrm{FeSO}_{4}$.

\section{FUNCTIONS IN PLANT METABOLISM}

Synthesis of the amino acids cystine, cysteine, and methionine, which are essential components of protein.

Necessary for chlorophyll formation, although not a component.

Activation of certain proteolytic enzymes such as papainases.

Synthesis of certain vitamins (biotin and thiamin or vitamin $B_{1}$ ), glutathione, and of coenzyme A.

Formation of the glucoside oils found in onions, garlic, and so on.

Formation of disulfide linkages associated with the structure of protoplasm.

Formation of ferredoxin, which has an important role in all photosynthetic processes.

Formation of ferredoxin-like compound involved in $\mathrm{N}$ fixation by nodule and free-living bacteria.

\section{EXTENT OF USE}

Worldwide production (1969), 29 million metric tons (32 million English tons) annually; of this total 18 million metric tons (19.8 English tons) are from elemental $\mathrm{S}$, and 11 million metric tons (12.1 English tons) are from pyrites. About one-half of this total is used in producing $\mathbf{P}$ fertilizers, ammonium sulfate, or for direct fertilizer application as $\mathbf{S}$.

Areas of $\mathrm{S}$ deficiency are increasing in the U.S. as well as in certain other countries. S deficiency for different crops has been reported in soils from 16 of the 50 U.S. States. This increasing deficiency has been brought about by the increased use of practically $S$-free fertilizers, higher crop yields, increased use of low-sulfur fuels and the emphasis on control of industrial emissions, by the decreased use of $S$ as an insecticide and fungicide and by the decreased levels of soil organic matter. 


\section{Sulfur-Continued}

FORMS USED BY PLANTS-Continued

Because known S-deficient soils are distributed widely throughout the world and the methods used to correct the deficiency differ greatly, a "representative" value of S applications to soils as a fertilizer is difficult to estimate. In applying $S$ directly to soils (that is, not as a component of $\mathrm{N}$, $\mathrm{P}$, or $\mathrm{K}$ fertilizers), either elemental $\mathrm{S}$ or gypsum is used, depending on relative cost. An example of application rates and yield response follows:

Alfalfa grown on S-deficient soil, California

\begin{tabular}{|c|c|c|c|}
\hline \multicolumn{3}{|c|}{ Treatment } & \multirow{2}{*}{$\begin{array}{c}\begin{array}{c}\text { Yield } \\
\text { (lb/acre/cutting) }\end{array} \\
550(616 \mathrm{~kg} / \mathrm{ha})\end{array}$} \\
\hline None & & & \\
\hline $\begin{array}{l}200 \mathrm{lb} / \text { acre } \\
\text { gypsum }\end{array}$ & $(244$ & $\mathrm{kg} / \mathrm{ha})$ & $\begin{array}{c}1,600(1,792 \\
\mathrm{kg} / \mathrm{ha})\end{array}$ \\
\hline $\begin{array}{l}400 \text { lb/acre } \\
\text { gypsum }\end{array}$ & (448 & $\mathrm{kg} / \mathrm{ha})$ & $\begin{array}{c}2,200(2,464 \\
\mathrm{kg} / \mathrm{ha})\end{array}$ \\
\hline
\end{tabular}

The addition of S to "normal" soils can increase the $S$ content of the crops, but the response is not uniform among species. An example follows:

Alfalfa grown on "normal" soil, Kentucky

\begin{tabular}{lc}
\hline Treatment & $\begin{array}{c}\text { Total } S \text { (\% dry weight) } \\
\text { in crop }\end{array}$ \\
\hline None & 0.36 \\
$100 \mathrm{lb} /$ acre $(112 \mathrm{~kg} / \mathrm{ha}) \mathrm{S}$ & .44 \\
$200 \mathrm{lb} /$ acre $(224 \mathrm{~kg} / \mathrm{ha}) \mathrm{S}$ & .48 \\
\hline
\end{tabular}

\section{LOSSES FROM SOILS \\ LEACHING}

Sulfate sulfur moves readily in the soil solution, and its loss through leaching is governed largely by physical, not chemical, properties of the soil, and by the organic content. For this reason, the losses range widely in different soils. An example follows:

Silty clay loam, Ithaca, N.Y., 10-15-yr averages, no runoff loss allowed (lb/ acre/yr)

Bare soil, 53 (59.4 kg/ha/yr)

Standard crop rotation, $43 \quad(48.2$

$\mathrm{kg} / \mathrm{ha} / \mathrm{yr}$ )

Continuous grass, $44(49.3 \mathrm{~kg} / \mathrm{ha} / \mathrm{yr})$

\section{EROSION}

Erosional losses can be severe, especially in clay soils where high $\mathrm{S}$ concentrations may occur in the surface layer. An example from Missouri experiments on soil subject to moderate erosion follows (lb/acre/yr):
Sulfur-Continued

FORMS USED BY PLANTS-Continued

Continuous corn (field bare between crops), 17 (19 kg/ha/yr)

Standard crop rotation, $6(6.6 \mathrm{~kg} / \mathrm{ha} / \mathrm{yr})$

\section{CROP REMOVAL}

The loss of $\mathrm{S}$ from soil by crop removal is similar to that of $P$. The approximate amount of $S$ removed by certain crops $(\mathrm{kg} / \mathrm{ha} / \mathrm{yr})$ follows:

Corn, yield $200 \mathrm{bu} / \mathrm{acre}(174 \mathrm{hl} / \mathrm{ha}), 49$ (43.7 $\mathrm{lb} / \mathrm{acre} / \mathrm{yr}$ )

Wheat, yield $80 \mathrm{bu} /$ acre $(70 \mathrm{hl} / \mathrm{ha}), 25$ (22.3lb/acre/yr)

Rice, yield $145 \mathrm{bu} /$ acre (126 hl/ha), 20 (17.8 $\mathrm{lb} / \mathrm{acre} / \mathrm{yr}$ )

Alfalfa, yield 6 tons/acre (13.4 metric tons/ha), 34 (30.3 lb/acre/yr)

Soybeans, yield $50 \mathrm{bu} /$ acre $(43.5 \mathrm{hl} / \mathrm{ha})$, 11 (9.8 lb/acre/yr)

Sugar beets, yield 30 tons/acre (67 metric tons/ha), 55 (49 lb/acre/yr)

Cabbage, yield 20 tons/acre (45 metric tons/ha), 41 (36.5 lb/acre/yr)

Potatoes, yield $400 \mathrm{bu} / \mathrm{acre}$ (348 hl/ha), 30 ( $26.7 \mathrm{lb} / \mathrm{acre} / \mathrm{yr})$

\section{OTHER (VOLATILIZATION)}

Sulfur compounds in the soil resemble $N$ compounds in that both can be lost by conversion to gaseous compounds through the action of bacteria. In highly organic soils under relatively severe anaerobic conditions, such as in swamps and bogs, much of the organic $S$ compounds and the free sulfate sulfur is converted to $\mathrm{H}_{2} \mathrm{~S}$ and lost from the soil. Estimates of this loss are not available.

\section{BALANCE SHEET}

The retention of sulfate sulfur in different soil types and the addition of $S$ to soils from the atmosphere and in fertilizers range widely; moreover, the amount of $S$ removed by crops varies greatly among species. Therefore, only a generalized balance can be estimated, as illustrated by the following example based on field experiments in Missouri (lb/acre/yr):

\section{ADDITIONS}

Atmospheric source........................................ 5

$(5.6 \mathrm{~kg} / \mathrm{ha} / \mathrm{yr})$

Fertilizers and manures .............................. $\frac{0}{5}$

Total Gain

$(5.6 \mathrm{~kg} / \mathrm{ha} / \mathrm{yr})$ 
Sulfur-Continued

FORMS USED BY PLANTS-Continued

LOSSES

Crop removal (average, standard

rotation)

$(16.8 \mathrm{~kg} / \mathrm{ha} / \mathrm{yr})$

Leaching

$(48.2 \mathrm{~kg} / \mathrm{ha} / \mathrm{yr})$

Erosion

$(6.7 \mathrm{~kg} / \mathrm{ha} / \mathrm{yr})$

Total Loss

64

$(56.7 \mathrm{~kg} / \mathrm{ha} / \mathrm{yr})$

Net Loss, 59 (51.1 kg/ha/yr)

If the above example is used, except that corn is grown continuously, the $S$ lost through erosion increases to $17(19 \mathrm{~kg} / \mathrm{ha} / \mathrm{yr})$, the leaching loss increases to $53(59.4 \mathrm{~kg} / \mathrm{ha} / \mathrm{yr})$, and crop removal increases to 49 (54.8 $\mathrm{kg} / \mathrm{ha} / \mathrm{yr}$ ), making a total of $119 \mathrm{lb} / \mathrm{acre} / \mathrm{yr}$ $(133 \mathrm{~kg} / \mathrm{ha} / \mathrm{yr})$ lost. Unless $\mathrm{S}$ fertilizers are added, and if the amount gained from the atmosphere remains $5 \mathrm{lb} / \mathrm{acre} / \mathrm{yr} \quad(5.6$ $\mathrm{kg} / \mathrm{ha} / \mathrm{yr}$ ), the net loss is $114 \mathrm{lb} / \mathrm{acre} / \mathrm{yr}$ (127.4 $\mathrm{kg} / \mathrm{ha} / \mathrm{yr}$ ). With different management practices, including sulfur application, the loss of S may be greatly reduced, or a gain in total S may be achieved, if leaching, erosion, and volatilization losses are not excessive.

\section{SOILS WHERE DEFICIENCIES ARE MOST COMMON}

Soils deficient in primary $\mathrm{S}$ minerals.

Sandy soils of warm temperate to tropical regions (excessive leaching).

Soils low in organic matter (poor $\mathrm{S}$ retention).

Soils of areas distant from industrial pollution.

Soils that have been heavily cropped with highsulfur plants.

\section{CALCIUM-(Ca)}

\section{OCCURRENCE IN NATURAL MATERIALS}

\section{ABUNDANCE IN SELECTED ROCKS}

From Connor, Shacklette, and others (1975), in percent

Granite, Precambrian; Missouri 0.53

Rhyolite, Precambrian; Missouri................ . .41

Sandstone

Sauk sequence; Western U.S.................. .99

Pennsylvanian; Kentucky ........................... . .28
Calcium-Continued

ABUNDANCE IN SELECTED-Continued

Shale

Sauk sequence; Western U.S.................. 2.8

Lower Mississippian; Kentucky ............... 4.9

Upper Mississippian; Kentucky .............. 3.1

Pennsylvanian; Kentucky ......................... . .29

Pennsylvanian; Missouri .......................... 2.9

Limestone and dolomite

Sauk sequence; Western U.S................. 20

Sauk sequence; Missouri ........................ 22

Upper Ordovician; Kentucky ................. 29

Tippecanoe sequence; Missouri ........... 32

Lower Mississippian; Kentucky ............. 25

Upper Missippippian; Kentucky ........... 33

Mississippian; Missouri........................... 32

Pennsylvanian; Kentucky ......................... 25

Pennsylvanian; Missouri ........................... 31

\section{ABUNDANCE IN “NATURAL” UNAMENDED SOILS}

MINERALS

Calcite, dolomite, gypsum, apatite, calcium feldspars, amphiboles, and many other lessimportant minerals. Much of the Ca present in soils is held on the surfaces of the colloids as adsorbed cations. These cations are easily released to the soil solution by exchanging with other cations.

\section{ORGANICS}

The concentration of $\mathrm{Ca}$ in plant tissues ranges widely among taxonomic groups, grasses and leaves of deciduous trees usually having high levels; whereas, the leaves of coniferous trees are low in $\mathrm{Ca}$. This $\mathrm{Ca}$ is released to the soil solution when the organic material decays and is cycled from soil to plant to soil in a loosely held cycle.

\section{ABUNDANCE IN SOILS}

"Representative" analysis of agricultural soils (as $\mathrm{Ca}$ : Humid region soils, $0.40 \%$ or $8,000 \mathrm{lb} / \mathrm{acre}$ furrow-slice $\quad(8,960 \mathrm{~kg} /$ ha-furrow-slice $)$ of $2,000,000 \mathrm{lbs}(908,000 \mathrm{~kg})$; arid region soils, $1.0 \%$ or $20,000 \mathrm{lb} /$ acre-furrow-slice $(22,400 \mathrm{~kg} / \mathrm{ha}$ furrow-slice). Ranges ordinarily expected: $0.07-3.6 \%$.

In 1,140 samples (10 from each Missouri county) of the surface horizon of agricultural soils, $0.41 \%$, range $<0.07-5.6 \%$.

Average, all U.S. soils, 2.4\%. Average, Eastern U.S. soils, $0.54 \%$. Average, Western U.S. soils, $3.24 \%$. 
Calcium-Continued

ABUNDANCE IN SOILS-Continued

Distribution of concentrations in U.S. surficial materials was given by Shacklette and Boerngen (1984). Concentrations in many cultivated and uncultivated U.S. soils were given by Connor, Shacklette, and others (1975).

ABUNDANCE IN PLANTS

Examples of the $\mathrm{Ca}$ concentration in vegetables and crop plants (geometric mean percent in ash) follow:

Lima bean seeds, central Georgia, 3

Soybean seeds, unglaciated prairie, Missouri, 6.2

Corn grains, Missouri floodplain, $\mathbf{0 . 3 0}$

Snap bean pods (fruit), central Georgia, 5.3

Cabbage leaves, northern Georgia, 16

$\mathrm{Ca}$ concentrations in stems and leaves of woody plants tend to be 2-3 times the concentration in seeds and fruits of crop plants. Examples (geometric mean percent in ash) follow:

Black gum stems, central Georgia, 25

Black gum leaves, central Georgia, 17

Red maple stems, central Georgia, 24

Red maple leaves, central Georgia, 17

White oak stems, Missouri, 33

Shortleaf pine, stems and leaves, Missouri, 13

Examples of $\mathrm{Ca}$ concentrations in forage, hay, and browse plants (geometric mean percent in ash) follow:

Johnson grass, Missouri floodplain, 6.1

Big bluestem grass, Missouri glaciated prairie, 5

Western wheatgrass, Western U.S., 4.4

Alfalfa, Western U.S., 21

Mesquite, Southwestern U.S., 28

Concentrations of $\mathrm{Ca}$ in a wide variety of cultivate and native plants were given by Connor, Shacklette, and others (1975).

A large number of species (mostly trees and shrubs) that were sampled at 910 widely distributed localities in the U.S. averaged $12 \%$ in ash.

\section{SOURCES FOR FERTILIZERS}

\section{GEOLOGIC OR OTHER PRINCIPAL} SOURCES

Limestone, dolomite, and gypsum. Generally, a dolomitic limestone is preferred for agricultural use in that essential magnesium is supplied at the same time. For most soils there should be at least one-third as much $\mathrm{Mg}$ as $\mathrm{Ca}$ in the lime applied in order to proportionately meet the outgo of the two constituents. If additional $\mathrm{Ca}$ is required as a plant nutrient in some alkali soils, gypsum is a satisfactory source of the element.
Calcium-Continued

INCIDENTAL GEOLOGIC OR OTHER SOURCES

MINERAL

Marl. A soft, unconsolidated deposit of calcium carbonate. It occurs in usable quantities in many of the Eastern States and is easily mined. Its value as liming material depends on its having low levels of incorporated clay. Marls are almost always low in magnesium.

Blast-furnace slag. A byproduct of pig iron manufacture. In the reduction of iron, the calcium carbonate loses its carbon dioxide, then the calcium oxide unites with the molten silica to form calcium silicate. This material is just as effective as limestone in crop production, if application rates are increased to counteract its lower $\mathrm{Ca}$ content.

Basic slag. A byproduct of the open-hearth process of making steel from pig iron. The impurities in the iron, including $\mathrm{P}$ and $\mathrm{Si}$, are fluxed with lime and slagged off. The pulverized material is used primarily for its $P$ content, but it also has a neutralizing value in soils equal to $65-80 \%$ of that of calcium oxide.

Electric-furnace slag. Results from the electric furnace reduction of phosphate rock in the preparation of elemental $P$. The slag is formed when the silica and calcium oxide fuse to form calcium silicate. It has a low (0.9-2.3\%) phosphate content, sells at a low price, and has a neutralizing value in soils equal to $65-80$ percent of that of calcium oxide.

Mine tailings. If largely composed of limestone and dolomite, is sometimes used as agricultural lime. Its content of certain toxic metals may preclude its use as a fertilizer.

\section{ORGANIC}

Shell deposits. In some coastal areas, large deposits of oyster or other shells occur and are used as a Ca source in industry and agriculture.

\section{REACTIONS WITH SOIL CONSTITUENTS}

The major importance of $\mathrm{Ca}$ as a soil amendment is its use to raise the $\mathrm{pH}$ of soils, rather than in correcting deficiencies as a plant nutrient. For optimum crop productivity, $\mathrm{Ca}$ must be the dominant base in the exchange complex. Its 
Calcium-Continued

REACTIONS WITH SOIL-Continued

widespread use in large amounts relates largely to maintaining this exchange relationship. In acid soils, $\mathrm{Ca}$ and other bases are replaced by hydrogen and aluminum ions. This acidity may increase solubility of $\mathrm{B}, \mathrm{Mn}, \mathrm{Al}, \mathrm{Cu}, \mathrm{Ni}$, and certain other elements to toxic concentrations, convert $P$ to the less soluble $\mathrm{Fe}$ and $\mathrm{Al}$ compounds, and cause Mo deficiency. Acidity also promotes breakdown of montmorillonitic clay minerals into kaolinitic forms that have lower exchange capacity. Below $\mathrm{pH} 5.5$, the rate of $\mathrm{N}$ fixation by micro-organisms begins to decrease, leading to $\mathrm{N}$ deficiency. In alkali soils and many saline soils, $\mathrm{Na}$ concentration increases at the expense of $\mathrm{Ca}$. Increased $\mathrm{Na}$ leads to higher soil $\mathrm{pH}$, resulting in depressed solubility and availability of $\mathrm{Ca}, \mathrm{P}, \mathrm{Mn}, \mathrm{Zn}, \mathrm{B}$, and $\mathrm{Fe}$. Structural deterioration of soil follows because of the dispersing effect of $\mathrm{Na}$, which adversely affects water movement, permeability, and aeration of soils. Toxic amounts of $\mathrm{Na}$ may be absorbed by plants. Therefore, $\mathrm{Ca}$ is used as a soil amendment in both acid and alkaline soils. A major effect of $\mathrm{Ca}$ is on soil structure, in that it promotes flocculation of clay particles, therefore improving soil tilth. $\mathrm{Ca}$ is the principal element used to correct soil toxicity problems.

\section{FORMS USED BY PLANTS}

Is absorbed by plant roots as the ion $\mathrm{Ca}^{+2}$ from the soil solution. This ion enters the soil solution from compounds such as $\mathrm{Ca}\left(\mathrm{NO}_{3}\right)_{2}, \mathrm{CaSO}_{4}$, $\mathrm{CaCl}_{2}, \mathrm{CaH}_{4}\left(\mathrm{PO}_{4}\right)_{2}, \mathrm{Ca}\left(\mathrm{HCO}_{3}\right)_{2}$, and others. It may also be absorbed by roots by the process of contact exchange.

\section{FUNCTIONS IN PLANT METABOLISM}

$\mathrm{Ca}$ functions in plants largely in the development of tissue structure and cell elongation. Calcium is deposited in the middle lamella of tissues, possibly as calcium pectate and is thought to be the "cementing" material that holds plant cells together. $\mathrm{Ca}$ is also believed to function in protein synthesis and is active in certain enzyme systems. $\mathrm{Ca}$ is considered to be an immobile element in plants, that is, it generally cannot move from older tissues to supply the $\mathrm{Ca}$ requirement of younger tissues. The amount of $\mathrm{Ca}$ in plant tissues is largely genetically controlled; the concentration in the soil solution exerts very little effect on this amount. Most soils contain sufficient $\mathrm{Ca}$ for the metabolic requirements of plants; $\mathrm{Ca}$ deficiencies of plants are rarely seen in the field.
Calcium-Continued

FORMS USED BY PLANTS-Continued

EXTENT OF USE

Annually, 26 million tons (23.6 million metric tons) of $\mathrm{Ca}$ as limestone are applied to soils in the U.S. This exceeds the tonnage of any other soil amendment used in this country, and contrasts to the 4.5 million tons ( 4.08 million metric tons) $\mathrm{N}, 3.4$ million tons (3.08 million metric tons) $\mathrm{P}_{2} \mathrm{O}_{5}$, and 2.7 million tons (2.44 million metric tons) $\mathrm{K}_{2} \mathrm{O}$ that are used annually. Soil scientists estimate that 80 million tons (72.6 million metric tons) of limestone should be used in this country for maximum crop production, especially in view of the high levels of $\mathrm{N}$ that are being used, which increase the demand for $\mathrm{Ca}$ by the crops. A general estimate suggests that $500-600 \mathrm{lb} / \mathrm{acre} / \mathrm{yr}$ $(560-672 \mathrm{~kg} / \mathrm{ha} / \mathrm{yr})$ may be required to meet the $\mathrm{Ca}$ loss from cropped soils in humid regions. Natural soils of humid regions generally are deficient in Ca for maximum crop production; whereas, arid soils commonly have sufficient Ca but its availability to plants may be reduced by excessive $\mathrm{Na}$. "Typical" application rates for $\mathrm{Ca}$ (as limestone) range from 4-16 tons/acre (4.48-9.69 metric tons/ha) broadcast on the soil surface then incorporated into the plow layer. Frequency of application depends on quantity applied, fineness of the material, and degree of $\mathrm{pH}$ correction necessary. As an example, in the North-central States, 2 tons of ground limestone per acre (4.48 metric tons/ ha) will usually replace the $\mathrm{Ca}$ loss from soil for a period of 10-20 years. Farther south, a greater annual supply must generally be provided.

\section{LOSSES FROM SOILS \\ LEACHING}

Leaching loss of $\mathrm{Ca}$ is much greater than loss in crop removal. An example of this loss follows:

Silty clay loam, Ithaca, N.Y., lb/acre/yr

Bare soil, 398 (445.8 kg/ha/yr)

Rotated cropland, 230 (257.6 kg/ha/yr)

Continuous grass, $260(291.2 \mathrm{~kg} / \mathrm{ha} / \mathrm{yr})$

\section{EROSION}

Loss of Ca by erosion, even on a $4 \%$ slope, may exceed the removal of $\mathrm{Ca}$ by crop plants. These losses are controlled by meteorological factors, soil structure, amount of $\mathrm{Ca}$ present, and vegetative cover, therefore ranging widely in amount. An example of Ca losses (lb/acre/yr) in Missouri experiments follows: 
Calcium-Continued

FORMS USED BY PLANTS-Continued

Corn, grown continuously, $220 \quad(246.4$ $\mathrm{kg} / \mathrm{ha} / \mathrm{yr}$ )

Rotation; corn, wheat, clover, 85 (95.2 $\mathrm{kg} / \mathrm{ha} / \mathrm{yr}$ )

CROP REMOVAL

The amount of $\mathrm{Ca}$ in plant tissues differs greatly among plant species and among plant organs. $\mathrm{Ca}$ is generally low in seeds and grains (soybean seeds, $5.6 \%$ in ash; corn grains, $0.3 \%$ in ash) and tubers and roots (potato, $0.8 \%$ in ash; beet roots, $1.8 \%$ in ash), but higher in leaves and stems (cabbage leaves, $16 \%$ in ash; tree leaves and stems, $15-30 \%$ in ash). The "average" Ca removal by a standard crop rotation is estimated to be $35 \mathrm{lb} / \mathrm{acre} / \mathrm{yr} \cdot(39.2 \mathrm{~kg} / \mathrm{ha} / \mathrm{yr})$. However, continuous monoculture where a crop containing high calcium is grown on a field year after year will result in much greater $\mathrm{Ca}$ loss by crop removal.

\section{BALANCE SHEET}

\section{ADDITIONS}

There are no natural means of consequence for replacing a total loss from the soil, although in special circumstances, some $\mathrm{Ca}$ may be added by windblown dust or carried in irrigation water. The management practices that can reduce this loss are the return of plant residues and animal manures to the soil, the use of fertilizers that contain calcium, and the application of lime to the soil.

\section{LOSSES}

An example of total $\mathrm{Ca}$ losses in cropland (lb/acre/yr), corn grown continuously, no crop rotation, based on Missouri and New York experiments, follows:

Erosion 220

$(246.4 \mathrm{~kg} / \mathrm{ha} / \mathrm{yr})$

Leaching loss

$(445.8 \mathrm{~kg} / \mathrm{ha} / \mathrm{yr})$

Crop removal.

\section{$(39.2 \mathrm{~kg} / \mathrm{ha} / \mathrm{yr})$}

Total Loss.

$\overline{653}$

(731.4 kg/ha/yr)

\section{SOILS WHERE DEFICIENCIES ARE MOST COMMON}

Acid soils (calcium saturation of the exchange complex less than $25 \%$ ).

Sandy soils, particularly where rainfall is over 30 in./yr (low supply, excessive leaching).
Calcium-Continued

SOILS WHERE DEFICIENCIES-Continued

Soils derived from serpentine (low total supply). Strongly acid peat soils (low supply, low availability).

Soils in which the dominant clay is montmorillonitic rather than kaolinitic (low availability).

Alkali or sodic soils where exchangeable $\mathrm{Na}$ and $\mathrm{pH}$ are high (low availability; excess of $\mathrm{Na}$ over $\mathrm{Ca})$.

\section{MAGNESIUM-(Mg)}

\section{OCCURRENCE IN NATURAL MATERIALS ABUNDANCE IN SELECTED ROCKS}

From Connor, Shacklette, and others (1975), in percent

Granite, Precambrian; Missouri 0.13

Rhyolite, Precambrian; Missouri. .10

Sandstone

Sauk sequence; Western U.S.................. . .33

Pope Megagroup; Kentucky.................... . .29

Pennsylvanian; Kentucky .......................... . .20

Pennsylvanian; Missouri ........................... . .56

Shale

Sauk sequence; Western U.S.................. 1.3

Lower Mississippian; Kentucky .............. 1.3

Upper Mississippian; Kentucky .............. 1.1

Mississippian; Missouri............................. 2.4

Pennsylvanian; Kentucky .......................... .73

Pennsylvanian; Missouri ........................... .99

Limestone and dolomite

Sauk sequence; Missouri ........................ 11

Ordovician; Kentucky................................. 2.3

Upper Ordovician; Kentucky .................. 3.2

Tippecanoe sequence; Missouri ............. 4.3

Lower Mississippian; Kentucky .............. 2.2

Upper Missippippian; Kentucky............. 1.6

Mississippian; Missouri............................. 2.3

Pennsylvanian; Kentucky ......................... 1.2

Pennsylvanian; Missouri ......................... 1.5

ABUNDANCE IN "NATURAL" UNAMENDED SOILS

MINERALS

Dolomite, serpentine, olivine, micas, and others. $\mathrm{Mg}$ is also held on clay in an exchangeable form.

\section{ORGANICS}

$\mathrm{Mg}$ in ash of plants ranges from about 0.14 to $>10 \%$; therefore, the organic constituents of soil provide a ready source of this element that is held in a loose soil-plant-soil cycle. The $\mathrm{Mg}$ that is solubilized from soil minerals by 
Magnesium-Continued

ABUNDANCE IN "NATURAL"-Continued

weathering may be held on soil organic matter in an exchangeable form and is available for plant use.

\section{ABUNDANCE IN SOILS}

"Representative" analysis of agricultural soils: Humid region soils, $0.30 \%$ or 6,000 lb/acre-furrow-slice $(6.720 \mathrm{~kg} /$ ha-furrow-slice $)$ weighing 2,000,000 $\mathrm{lb}(908,000 \mathrm{~kg})$; arid region soils, $0.60 \%$ or $12,000 \mathrm{lb} / \mathrm{acre}$-furrow-slice $(13,440 \mathrm{~kg} / \mathrm{ha}$-furrow-slice). Range ordinarily expected, $0.12-1.50 \%$.

In 1,140 samples (10 from each Missouri county) of the surface horizon of agricultural soils, $0.28 \%$, range $0.05-2.8 \%$.

Average, all U.S. soils, $0.92 \%$.

Average, Eastern U.S. soils, $0.48 \%$.

Average, Western U.S. soils, $1.01 \%$.

Distribution of concentrations in U.S. surficial materials was given by Shacklette and Boerngen (1984). Concentrations in many cultivated and uncultivated U.S. soils was given by Connor, Shacklette, and others (1975).

ABUNDANCE IN PLANTS

$\mathrm{Mg}$ levels tend to be slightly higher in seeds and grains than in the vegetative parts of plants. Examples of $\mathrm{Mg}$ concentrations in vegetables and crop plants (geometric mean percent in ash) follow:

Lima bean seeds, central Georgia, 3.4

Soybean seeds, unglaciated prairie, Missouri, 3.2

Corn grains, Missouri floodplain, 6.2

Snap bean pods (fruit), central Georgia, 3.6

Cabbage leaves, northern Georgia, 2.7

The $\mathrm{Mg}$ content of stems and leaves of woody plants are about equal. Examples (geometric mean percent in ash) follow:

Black gum stems, central Georgia, 5.7

Black gum leaves, central Georgia, 5.9

Red maple stems, central Georgia, 2.5

Red maple leaves, central Georgia, 2.3

White oak stems, Kentucky, 2.0

Shortleaf pine stems and leaves, Missouri, 3.5

Examples of $\mathrm{Mg}$ concentrations in forage, hay, and browse plants (geometric mean percent in ash) follow:

Johnson grass, Missouri floodplain, 2.9

Big bluestem grass, Missouri glaciated prairie, 1.5

Western wheatgrass, Western U.S., 1.1

Alfalfa, Western U.S., 2.8

Mesquite, Southwestern U.S., 2.9
Magnesium-Continued

ABUNDANCE IN PLANTS-Continued

The $\mathrm{Mg}$ content of a large number of cultivated and native plant species was given by Connor, Shacklette, and others (1975).

SOURCES FOR FERTILIZERS

GEOLOGIC OR OTHER PRINCIPAL SOURCES

The most widely used material for general application is dolomite or dolomitic limestone. If $\mathrm{Mg}$ is to be added to mixed fertilizers, potassium magnesium sulfate $\left(\mathrm{K}_{2} \mathrm{SO}_{4}, \mathrm{MgSO}_{4} ; 18 \% \mathrm{~K}, 11 \%\right.$ $\mathrm{Mg}, 18 \% \mathrm{~S}$ ) is often used. Magnesium sulfate alone may be used, and also magnesia which is made by calcining magnesite or brucite to give magnesium oxide.

\section{INCIDENTAL GEOLOGIC OR OTHER} SOURCES

\section{MINERALS}

Asbestos tailings

Basic slag, 3.4\% Mg

Well brines and sea water. These materials are treated with calcium hydroxide and heated to produce $\mathrm{MgO}(55 \% \mathrm{Mg})$.

ORGANICS

Animal manures, 1.6-5.8 $\mathrm{lb} /$ English ton (0.66-2.38 kg metric tons) $\mathrm{Mg}$.

Sewage sludge, $6-16 \mathrm{~kg} / \mathrm{metric}$ ton of solids (14.6-38.9 lb/English ton) $\mathrm{Mg}$.

\section{REACTIONS WITH SOIL CONSTITUENTS}

If solubilized from soil minerals by weathering, $\mathrm{Mg}$ may be held on clay or organic matter in an exchangeable form. If calcitic limestone is applied to the soil, some of the exchangeable $\mathrm{Mg}$ will be replaced by $\mathrm{Ca}$, and the $\mathrm{Mg}$ may be leached from the soil. Plant deficiencies of $\mathrm{Mg}$ may result if the $\mathrm{Ca}: \mathrm{Mg}$ ratio is too wide-about 7:1 is the best ratio in most soils. High levels of available soil $\mathrm{K}$ generally reduce $\mathrm{Mg}$ uptake by plants, especially in low-Mg soils. This interaction results from an excessively wide ratio of exchangeable $K$ to exchangeable $\mathrm{Mg}$, and soils having this ratio may produce pastures (especially grass) that are extremely low in $\mathrm{Mg}$ (grasses having < $0.2 \% \mathrm{Mg}$ in dry weight). Animals grazing this grass may develop a nutritional disease called hypomagnesanemia or grass tetany (Mortvedt and Cunningham, 1971, p. 425). The use of soluble $\mathrm{Mg}$ fertilizers, such as $\mathrm{MgSO}_{4}$, has been reported to reduce $\mathrm{Zn}$ deficiency symptoms in some crop plants, but the chemical interactions are not well understood.

\section{FORMS USED BY PLANTS}

$\mathrm{Mg}$ is absorbed by plants as the ion $\mathrm{Mg}^{+2}$ from the soil solution. It may possibly also be absorbed 
Magnesium-Continued

FORMS USED BY PLANTS-Continued

by the mechanism of contact exchange. Some compounds in which the $\mathrm{Mg}$ is readily available to plants are $\mathrm{MgO}, \mathrm{MgSO}_{4}, \mathrm{MgCl}_{2}$, and $\mathrm{Mg}\left(\mathrm{HCO}_{3}\right)_{4}$.

FUNCTIONS IN PLANT METABOLISM

$\mathrm{Mg}$ is the only mineral constituent of the chlorophyll molecule and is essential for the process of photosynthesis with about $10 \%$ of the $\mathrm{Mg}$ in leaves in the chlorophyll. $\mathrm{Mg}$ is required for activation of enzymes that function in carbohydrate metabolism and is involved in the citric acid cycle of cell respiration. $\mathrm{Mg}$ catalyzes numerous phosphorylation reactions related to $\mathrm{N}$ metabolism in plants and also functions in the synthesis of oils.

EXTENT OF USE

Because $\mathrm{Mg}$ is not widely applied as a pure compound, but as a constituent of liming materials in dolomitic limestone, data are not available as to annual amount used. The amounts lost from soils in agricultural operations are usually replaced by liming that is aimed principally at correcting soil acidity. For this reason, the material used in liming soil should contain at least one-third as much $\mathrm{Mg}$ as $\mathrm{Ca}$ in order to proportionately replenish the loss of these two elements.

For certain crops in some areas, $\mathrm{Mg}$ deficiencies are severe and may be corrected by direct application of $\mathrm{Mg}$ compounds to the soil or directly to plants in a foliar spray. Examples of $\mathrm{Mg}$ applications follow:

Applied to soil

Apple trees, $400 \mathrm{lb} / \mathrm{acre}(448 \mathrm{~kg} / \mathrm{ha})$ magnesium sulfate corrected deficiency in 2-3 years.

Potatoes, $60-100 \mathrm{lb} / \mathrm{acre}(67-112 \mathrm{hl} / \mathrm{ha})$ magnesium sulfate, or 20-30 lb/acre $(33.6-44.8 \mathrm{~kg} / \mathrm{ha})$ magnesium oxide.

Soybeans, 30-40 lb/acre (33.6-44.8 kg/ha) magnesium oxide.

Cauliflower, $300 \mathrm{lb} / \mathrm{acre} \quad(336 \mathrm{~kg} / \mathrm{ha})$

magnesium oxide.

Foliar spray

Apple trees with severe deficiency, 8 sprays using $20 \mathrm{lb}(2.4 \mathrm{~kg})$ magnesium sulfate per 100 gallons (378.4 I) of water, applied at 1- to 2-week intervals.

Orange trees, $10 \mathrm{lb}(1.2 \mathrm{~kg})$ magnesium nitrate per 100 gallons (378.4 l) of water. One report stated that a spray with a $2 \%$ suspension in water of finely ground burnt dolomite corrected the Mg deficiency.
Magnesium-Continued

FORMS USED BY PLANTS-Continued

LOSSES FROM SOILS

LEACHING

Loss of $\mathrm{Mg}$ by leaching is roughly the same as the loss by crop removal but is markedly affected by factors, such as fertilization levels, cropping patterns, and soil texture and drainage. An example of leaching loss follows:

Representative humid-region loam cropped to a standard rotation, $20 \mathrm{lb} / \mathrm{acre} / \mathrm{yr}$ ( 22.4 $\mathrm{kg} / \mathrm{ha} / \mathrm{yr}$ ).

\section{EROSION}

Loss of $\mathrm{Mg}$ by erosion, even on a $4 \%$ slope, may exceed the removal of $\mathrm{Mg}$ by crop plants. The control of $\mathrm{Mg}$ erosional losses is essentially the same as that for Ca losses. An example of $\mathrm{Mg}$ losses by erosion (lb/acre/yr) in Missouri experiments follows:

Corn, grown continuously, $87 \quad$ (97.4 $\mathrm{kg} / \mathrm{ha} / \mathrm{yr}$ )

Rotation; corn, wheat, clover, 29 (32.4 $\mathrm{kg} / \mathrm{ha} / \mathrm{yr}$ )

\section{CROP REMOVAL}

Plant species and varieties differ both in their $\mathrm{Mg}$ requirement and in their $\mathrm{Mg}$ concentration in tissues. $\mathrm{Mg}$ concentrations also tend to differ in the several plant organs. $\mathrm{Mg}$ in seeds and grains tend to range from $2.5-5 \%$ in ash, but corn grains have a range of greater values, about 6-13\%. Ash of stems and leaves from both herbaceous and woody plants ranges from $3-7 \% \mathrm{Mg}$, with exceptional values of 10 percent or greater.

Losses by crop removal in a standard rotation of corn, wheat, and legumes are estimated to be about $25 \mathrm{lb} / \mathrm{acre} / \mathrm{yr}(28 \mathrm{~kg} / \mathrm{ha} / \mathrm{yr})$.

\section{BALANCE SHEET}

\section{ADDITIONS}

There is no important natural process for replacing soil losses, although under special conditions some $\mathrm{Mg}$ may be added by windblown dust or in irrigation water. Loss can be corrected by return of plant residues and animal manures to the soil, use of $\mathrm{Mg}$ containing fertilizers, and application of dolomitic limestone.

\section{LOSSES}

An estimate of total $\mathrm{Mg}$ losses (lb/acre/yr) in a standard rotation silt loam soil, humid region, follows: 
Magnesium-Continued

FORMS USED BY PLANTS-Continued

Erosion. 29

$(32.4 \mathrm{~kg} / \mathrm{ha} / \mathrm{yr})$

Leaching loss.

$(22.4 \mathrm{~kg} / \mathrm{ha} / \mathrm{yr})$

Crop removal.

$(28.0 \mathrm{~kg} / \mathrm{ha} / \mathrm{yr})$

Total Loss.

$(82.8 \mathrm{~kg} / \mathrm{ha} / \mathrm{yr})$

Some soils of arid regions have an excess of $\mathrm{Mg}$, therefore loss from the soil may be beneficial. For example, in a heavy clay soil in the Napa Valley, California, more than $90 \%$ of the cation exchange capacity was saturated with $\mathrm{Mg}$, which rendered the soil almost completely unproductive.

\section{SOILS WHERE DEFICIENCIES ARE MOST} COMMON

Acid, sandy soils receiving moderate to high rainfall.

Imperfectly drained clay soils.

Peat and muck soils.

\section{Minor Essential Elements (Micronutrients)}

\section{BORON-(B) \\ OCCURRENCE IN NATURAL MATERIALS \\ ABUNDANCE IN SELECTED ROCKS}

From Connor, Shacklette, and others (1975), in parts per million (ppm)

Granite, Precambrian; Missouri ............... $<20$

Rhyolite, Precambrian; Missouri.............. $<20$

Arkose, Fountain Formation; Colorado.. $\quad 6.7$

Sandstone

Roubidoux Formation; Missouri .............. 20.7

Pope Megagroup; Kentucky....................... 19.8

Pennsylvanian; Kentucky ............................ 22.0

Pennsylvanian; Missouri............................... 43.2

Shale

Sauk sequence; Western U.S................. 60.2

Lower Mississippian; Kentucky .............. 79.2

Upper Mississippian; Kentucky ............. 74.8

Mississippian; Missouri........................... 70.4

Pennsylvanian; Kentucky ........................ 58.8

Pennsylvanian; Missouri ......................... 73.4

Black shale, Devonian and Mississippian;

Kentucky.

Limestone and dolomite

Upper Ordovician; Kentucky

Tippecanoe sequence; Missouri ............ $<20$

Lower Mississippian; Kentucky ............. 31.9

Upper Missippippian; Kentucky............ $<50$
Boron-Continued

ABUNDANCE IN SELECTED-Continued Mississippian; Missouri......................... $<20$

Pennsylvanian; Kentucky ........................ $<50$

Pennsylvanian; Missouri ...................... $<20$

\section{ABUNDANCE IN "NATURAL" UNAMENDED SOILS \\ MINERALS}

Tourmalines (borosilicates, about $10 \% \mathrm{~B}$ ) are the main B-containing minerals, and are very slowly soluble. Precipitated $\mathrm{Al}(\mathrm{OH})_{3}$ adsorbs large amounts of $\mathrm{B}$; liming of acid soils increases adsorption due to increase in amount of exchangeable $\mathrm{Al}$.

\section{ORGANICS}

Most of the available soil B is held by the organic fraction, where it is retained until the organic matter decomposes; then B is released, taken up by plants, held in clay lattices, or lost by leaching.

\section{ABUNDANCE IN SOILS}

"Representative" analysis of agricultural soils, 50 ppm (100 lb/acre-furrow-slice; $112 \mathrm{~kg} / \mathrm{ha}$-furrowslice), range $50-150 \mathrm{ppm}$.

In 1,140 samples (10 from each Missouri county) of the surface horizon of agricultural soils, 33 ppm; range $<20-700 \mathrm{ppm}$.

Average, all U.S. soils, 34 ppm

Average, Eastern U.S. soils, 38 ppm.

Average, Western U.S. soils, 28 ppm.

Distribution of concentrations in U.S. surficial materials was given by Shacklette and Boerngen (1984). Concentrations in many cultivated and uncultivated U.S. soils were given by Connor, Shacklette, and others (1975).

\section{ABUNDANCE IN PLANTS}

The concentrations are strongly genetically controlled and range widely among different plant families and species. There is also a wide range among different plant organs. Soil concentrations of available $B$ also influence plant contents. For a particular species of plant, differences between deficient levels and toxic levels in soils commonly are very small. Much higher concentrations of B occur in plant than in animal tissues.

Most dicotyledonous plants (broad leafed, as in common herbs and trees) have higher B requirement than do monocotyledonous plants (narrow leafed, as in grasses). Perennial crop plants, such as alfalfa, clover, fruit and nut trees, tend to suffer B deficiencies more commonly than do annual crop plants. Members of the mustard family (cabbage, cauliflower, and turnip, for 
Boron-Continued

ABUNDANCE IN PLANTS-Continued example) have both a high $B$ requirement and a high $B$ tolerance; whereas, cereal crops have a low requirement and low tolerance.

Legumes (beans, peas, and peanuts, for example) generally are richest in B (25-50 ppm, dry weight basis), followed by fruits and vegetables (5-20 ppm), with cereal grains and hays the poorest (1-5 ppm). Concentrations found in 895 samples of a wide variety of plants from throughout the U.S. (mostly trees and shrubs) averaged $314 \mathrm{ppm}$ in ash, and ranged from $<30-2,000 \mathrm{ppm}$.

Concentrations of $\mathrm{B}$ in many vegetables and native plants of the U.S. are given by Connor, Shacklette, and others (1975).

\section{SOURCES FOR FERTILIZERS}

\section{GEOLOGIC OR OTHER PRINCIPAL} SOURCES

Borax, $\mathrm{Na}_{2} \mathrm{~B}_{4} \mathrm{O}_{7} \cdot 10 \mathrm{H}_{2} \mathrm{O}, 16.6 \%$ B. Soluble in water; is absorbed rapidly by plants, and readily leached from soils. The most widely used form in fertilizers.

Colemanite, $\mathrm{Ca}_{2} \mathrm{~B}_{6} \mathrm{O}_{11} \cdot 5 \mathrm{H}_{2} \mathrm{O}, 50.95 \% \quad \mathrm{~B}_{2} \mathrm{O}_{3}$. Considerably less soluble than borax, therefore superior as a soil fertilizer, particularly on light, sandy soils. Supplies of this mineral in the U.S. have been largely depleted.

Kernite, $\mathrm{Na}_{2} \mathrm{~B}_{4} \mathrm{O}_{7} \cdot 4 \mathrm{H}_{2} \mathrm{O}, 51.0 \% \mathrm{~B}_{2} \mathrm{O}_{3}$. In the U.S. the $\mathrm{B}$ mineral mined in the largest quantities. It is unusual in that crystallization of a water solution of the ore mineral yields 1.59 times as much of the desired product, borax.

Howlite, $\mathrm{Ca}_{2} \mathrm{SiB}_{5} \mathrm{O}_{9}(\mathrm{OH})_{5}, 44.6 \% \mathrm{~B}_{2} \mathrm{O}_{3}$. Slowly soluble, therefore a desirable $\mathrm{B}$ fertilizer material.

Borosilicate glass (frits), 3-6\% B. Made by fusion of $B$ compounds with glass, it extends the period of availability of $B$ in soils and is becoming widely used. Rate of $B$ release to the soil solution can be regulated to meet the needs of a particular crop by controlling the particle size of the frits.

\section{INCIDENTAL GEOLOGIC OR OTHER SOURCES}

IRRIGATION WATER

If the $B$ content of irrigation water is $0.16-0.20$ ppm or more and 1 acre-foot $\left(1,233.6 \mathrm{~m}^{3}\right)$ is used, B deficiency is unlikely. If the B content is
Boron-Continued

INCIDENTAL GEOLOGIC-Continued greater than $0.75 \mathrm{ppm}$, some sensitive plants (citrus trees, among others) will show toxicity symptoms.

MINERAL

Chilean sodium nitrate. Use of this fertilizer in the U.S. is insignificant at the present time.

Boron has been reported as an atmospheric contaminant of soils, having originated in soot from the burning of coal for domestic use. Samples of this soot contained 555-650 ppm water-soluble B.

\section{ORGANIC}

Sewage sludge commonly contains considerable B; however, estimates of amounts are not available. Night soil (human excrement) in Paris, France, contained an average B content of $23.3 \mathrm{ppm}$ in dry matter. At the application rate used on horticultural crops, 100 metric tons/ha/yr (44.6 English tons/ acre/yr), night soil supplied $1.4 \mathrm{~kg} / \mathrm{ha} / \mathrm{yr}(1.2$ $\mathrm{lb} / \mathrm{acre} / \mathrm{yr}) \mathrm{B}$, the equivalent of a 12-kg (26.4 lb) borax application.

Animal manures are only slightly less rich in B; the "average" concentration was reported as $20.2 \mathrm{ppm}$ in dry matter, with a range of $4.5-52$ ppm.

\section{REACTIONS WITH SOIL CONSTITUENTS}

Reactions include sorption of $\mathrm{B}$ as borate ions $\left(\mathrm{H}_{3} \mathrm{BO}_{4}{ }^{-2}\right)$ or as molecular $\mathrm{H}_{3} \mathrm{BO}_{3}$, precipitation of insoluble $\mathrm{B}$ with alumina and silica, and entry of $B$ into clay mineral lattices which increases markedly with increasing $\mathrm{pH}$. This latter reaction is rapid and reversible, and reactivity is in a decreasing order with illite, kaolinite, and montmorillonite. $B$ is readily bound to the organic fraction of soils.

Applications of $\mathbf{K}$ fertilizers aggravate $\mathbf{B}$ deficiencies in some crop plants. Increased $\mathrm{Ca}$ concentrations decrease B toxicity at high B levels in soils and increase B deficiency symptoms at low $B$ levels in soil.

\section{FORMS USED BY PLANTS}

Probably absorbed as boric acid, $\mathrm{H}_{3} \mathrm{BO}_{3}$, from the soil solution in acid soils; in basic soils possibly largely absorbed by contact exchange at root surface.

\section{FUNCTIONS IN PLANT METABOLISM}

Required for the processes of cell differentiation and maturation and for optimum rate of water absorption. The 
Boron-Continued

FORMS USED BY PLANTS - Continued

reactions involved are not known but possibly are enzyme related. $B$ is thought to prevent excessive polymerization of sugars at sites of sugar synthesis, and therefore to aid in sugar translocation. Deficiencies of $B$ lead to breakdown of meristematic tissues and parenchyma and to poor development of vascular tissue.

\section{EXTENT OF USE}

The estimated amount of B (expressed on an elemental basis) sold for fertilizer in the U.S. in fiscal 1969 was 2,250 metric tons (2,480 English tons).

The range between soil deficiency and toxicity for many plants is narrow. The very small amounts usually applied per acre require it to be added to other fertilizers, inert "filler" material, or water in order to permit even distribution on the soil.

Application rates range widely among different soils and crops. The rates of $0.25-3 \mathrm{~kg} / \mathrm{ha} / \mathrm{yr}$ (0.22-2.7 lb/acre/yr) are generally recommended if deficiency symptoms appear in a crop, the lower rate for the more sensitive crops, such as corn, and the higher rates for B-tolerant crops, such as alfalfa. Foliar applications as a spray of $15-60 \mathrm{~g}(0.5-2.1$ ounces) of $B$ per tree are generally recommended for correcting deficiencies of fruit and nut crops. Repeated applications of $B$ fertilizers over a long time may result in B toxicity in soils for B-sensitive species.

\section{SOILS WHERE DEFICIENCIES ARE MOST COMMON}

Soils naturally low in B, such as those derived from acid igneous rocks or from freshwater sedimentary deposits.

Naturally acid soils where much of the original B content has been removed by leaching.

Light-textured, sandy soils (excessive leaching).

Acid peat and muck soils.

Alkali soils, especially those containing free lime.

Irrigated soils where B content of water is low, and where salt or carbonate deposition has occurred.
Boron-Continued

SOILS WHERE DEFICIENCIES-Continued

Soils low in organic matter.

Regions in the U.S. in which the soils are particularly low in B are the Atlantic and Gulf coasts from Maine to Texas, the North-central States, California, and the Pacific Northwest.

\section{CHLORINE-(Cl)}

\section{OCCURRENCE IN NATURAL MATERIALS}

ABUNDANCE IN SELECTED ROCKS

From Turekian and Wedepohl (1961), in parts per million (ppm)

Igneous

Ultrabasic, 85

Basaltic, 60

Granitic

High calcium, 130

Low calcium, 200

Sedimentary

Shales, 180

Sandstones, 10

Carbonates, 150

ABUNDANCE IN “NATURAL" UNAMENDED SOILS

MINERALS

The $\mathrm{Cl}$ ion is highly soluble in water, therefore readily dissociates from most compounds and enters the soil solution. It is not adsorbed on soil colloids. The common source of $\mathrm{Cl}$ in natural soils is halite $(\mathrm{NaCl})$, but it occurs as crystals only in very dry soils. $\mathrm{Cl}$ may accumulate in humid area soils solutions where drainage is impeded.

\section{ORGANICS}

Because of the high solubility of $\mathrm{Cl}$, it is rapidly leached from the nonliving organic matter of soils. Therefore, soil humus is not an important reservoir of soil $\mathrm{Cl}$.

\section{ABUNDANCE IN SOILS}

"Representative" analysis of agricultural soils, 50 ppm (100 lb/acre-furrow-slice, or 112 kg/ha-furrow-slice; range, $10-1,000 \mathrm{ppm}$. One measurement of the yearly average $\mathrm{Cl}$ in a productive agricultural soil was reported as 8,519 $\mathrm{kg}$ /ha-furrow-slice depth $(9,550 \mathrm{lb} /$ acre-furrowslice).

\section{ABUNDANCE IN PLANTS}

A general estimate of the $\mathrm{Cl}$ content of plants is $0.025 \%$ in dry tissue, or expressed another way, one pound of $\mathrm{Cl}$ in each 4,000 pounds $(2.2$ $\mathrm{kg} / 1,000 \mathrm{~kg}$ ) of dry matter produced. $\mathrm{Cl}$ accumulates in plant tissue with age, and young 
Chlorine-Continued

ABUNDANCE IN PLANTS-Continued

leaves can contain less than optimum amounts while older leaves on the plant may have already accumulated a toxic excess. One measurement of seasonal accumulation in leaf stalks of grape was reported as follows (percent, dry weight basis):

October 25, 0.62

December 20, 1.37

February 15, 2.11

The $\mathrm{Cl}$ content ranges widely among both species and organs of plants. For example, with stone fruits (like peaches, plums, and cherries), one investigator found $\mathrm{Cl}$ concentrations in roots and leaves to be about the same, followed by concentrations in bark, with the wood having about one-tenth as much as in the leaves. Some examples of the "normal" concentration in crop plants follow (percent, in dry matter):

Barley, stems and leaves, 4.20-4.40

Bean, leaves, 2.69-5.65

Carrot, roots, 1.07

Corn, leaves, 2.11

Potato, stems and leaves, 0.83

Onion, bulbs, 0.25

Date palm fruit, 0.16-0.69.

A comparison of the $\mathrm{Cl}$ in soils and in plant stems and leaves in one experiment in Wisconsin follows:

Soils, 0-6-in. (0-15.2 cm) depth, $34 \mathrm{lb} /$ acre

furrow-slice (38 kg/ha-furrow-slice)

Plants, $30 \mathrm{lb} /$ acre (33.5 kg/ha)

A study in California determined the yearly average $\mathrm{Cl}$ in soils and plants as follows ( $\mathrm{kg} / \mathrm{ha}$ furrow-slice):

Soils, 8,519 (9,550 lb/acre-furrow-slice)

Soil bacteria, 1,589 (1,781 lb/acre-furrow-slice)

Vascular (higher) plants, 1,918 (2,150 lb/acre-

furrow-slice)

\section{SOURCES FOR FERTILIZERS}

\section{GEOLOGIC OR OTHER PRINCIPAL SOURCES}

Production of $\mathrm{Cl}$ primarily for direct application (as a salt) to correct $\mathrm{Cl}$ deficiencies of soils is of little importance. The $\mathrm{Cl}$ supplied by natural processes, in addition to the $\mathrm{Cl}$ in fertilizers, generally meet the needs of crop plants. However, common salt $(\mathrm{NaCl})$ or potassium chloride $(\mathrm{KCl})$ is used on soils that have a natural $\mathrm{Cl}$ deficiency, and of course halite and sylvite deposits and brines constitute the geologic sources.
Chlorine-Continued

INCIDENTAL GEOLOGIC OR OTHER SOURCES

ATMOSPHERIC

The $\mathrm{Cl}$ brought down in rainfall largely originates from sea water; therefore, the annual rate of deposition on soil is related to distance from the sea and prevailing wind direction. The salt is injected into the atmosphere as particles 0.1-1 micrometer or larger from oceans by the bursting of air bubbles as they reach the surface. In areas near the sea, deposits of 100 $\mathrm{lb} / \mathrm{acre} / \mathrm{yr}(112 \mathrm{~kg} / \mathrm{ha} / \mathrm{yr})$ or more are common. Measurements made at Geneva, New York, and at Madison, Wisconsin, indicated an annual deposit of $16 \mathrm{lb} /$ acre $(167.9 \mathrm{~kg} / \mathrm{ha})$. Some reports suggest that $\mathrm{Cl}$ is added to soil from industrial emissions, but supporting data are not available.

\section{IRRIGATION WATER}

The most common problem is with excess, rather than inadequate, amounts for crop production. Irrigation water containing 500 ppm $\mathrm{Cl}$ as $\mathrm{NaCl}$ is immediately injurious to Cl-sensitive plants, such as avocado, and longtime use of this water may lead to excesses in soils for many crops. One extremely resistant crop plant to $\mathrm{Cl}$, asparagus, seldom is injured by $\mathrm{Cl}$ concentrations in soils, and is an important crop plant in some coastal salt marshes, particularly in Taiwan.

\section{ORGANIC}

$\mathrm{Cl}$ released by plant decomposition is quickly absorbed by nearby living plants. If none is present, the $\mathrm{Cl}$ generally is soon lost from the soil by leaching.

\section{REACTIONS WITH SOIL CONSTITUENTS}

$\mathrm{Cl}$ accumulation in soils is reduced if concentrations of either nitrate or sulfate ions are increased. The addition of superphosphate fertilizers was found in one study to have synergistic effect on $\mathrm{Cl}$ uptake. Excess soil $\mathrm{Cl}$ depresses the absorption by plants of nitrates and sulfates. Some experiments indicated that leaves accumulate higher $\mathrm{Cl}$ if calcium chloride is substituted for sodium chloride. If the calcium ion is the dominant cation in the plant root, the negative potential is low and more $\mathrm{Cl}$ ions accumulate than if sodium is the dominant cation. The addition of $\mathrm{Cl}$ increases silicon absorption by plants from Si-deficient solutions. 
Chlorine-Continued

FORMS USED BY PLANTS

$\mathrm{Cl}$ is absorbed from the soil solution as the $\mathrm{Cl}^{-1}$ ion, or directly by leaves from atmospheric $\mathrm{NaCl}$ deposits on the leaves.

\section{FUNCTIONS IN PLANT METABOLISM}

$\mathrm{Cl}$ was only recently classified as an essential element for plants, although it is used in larger quantities by crop plants than any other micronutrient except iron. Little is known of its metabolic function other than that it is required for growth and development. Recent research indicates that $\mathrm{Cl}$ functions in the photosynthetic reactions of chloroplasts in the electron-flow mechanism of cyclic phosphorylation. Older literature reported that $\mathrm{Cl}$ was necessary for carbohydrate translocation, but recent experiments cast some doubt on this function. Bromine, at somewhat higher concentrations than $\mathrm{Cl}$, can substitute for $\mathrm{Cl}$, at least in part. Plant species differ in their resistance to $\mathrm{Cl}$ deficiencies in the soil solution. Plants that suffer the least, such as corn, beans, and squash, are those that are able to make more efficient use of atmospheric $\mathrm{Cl}$.

Increase of $\mathrm{Cl}$ in the soil solution, up to a certain point, increases the osmotic concentration of plant cell sap. This elevated osmotic pressure may influence the absorption of other elements from the soil solution.

\section{EXTENT OF USE}

Chlorine salts, except $\mathrm{KCl}$, are not widely used as fertilizers; additions of $\mathrm{Cl}$ from the atmosphere are believed to be adequate to meet crop needs in almost all localities. Commercial fertilizers commonly supply additional amounts of $\mathrm{Cl}$ to crop plants, especially the $\mathrm{K}$ fertilizers. $\mathrm{Cl}$ deficiency in crop plants is marked by fairly well-defined morphological symptoms. If these symptoms appear, the general recommendation is to apply $20 \mathrm{lb} /$ acre $(22.4 \mathrm{~kg} / \mathrm{ha}) \mathrm{Cl}$ in fertilizer mixtures (often as $\mathrm{KCl}$ ).

\section{SOILS WHERE DEFICIENCIES ARE MOST COMMON}

Soils at locations far inland from the sea.

Coarse-textured soils (sands, sandy loams) where rapid leaching occurs.

Soils that are heavily cropped with high-Cl plants. Soils left bare of vegetation (no cover crop) for part of every year.

Soils low in organic matter.

\section{COPPER-(Cu)}

\section{OCCURRENCE IN NATURAL MATERLALS}

\section{ABUNDANCE IN SELECTED ROCKS}

From Connor, Shacklette, and others (1975), in parts per million (ppm)

Granite, Precambrian; Missouri ................. 2.6

Rhyolite, Precambrian; Missouri............... 2.1

Arkose, Fountain Formation; Colorado... 8.9

Sandstone

Sauk sequence; Western U.S................. 8.0

Roubidoux Formation; Missouri............ 1.6

Pope Megagroup; Kentucky.................... 9.2

Pennsylvanian; Kentucky ......................... 8.5

Pennsylvanian; Missouri ......................... 12.6

Shale

Sauk sequence; Western U.S................ 23.1

Lower Mississippian; Kentucky ............ 16.8

Upper Mississippian; Kentucky ........... 19.2

Mississippian; Missouri........................... 20.8

Black shale

Devonian and Mississippian; Kentucky 143

Limestone and dolomite

Sauk sequence; Western U.S.................. 6.4

Sauk sequence; Missouri ......................... 3.0

Upper Ordovician; Kentucky ................... 6.1

Tippecanoe sequence; Missouri ............. $\quad 1.8$

Lower Mississippian; Kentucky ............... 4.8

Upper Missippippian; Kentucky ............. 3.1

Mississippian; Missouri............................ 1.0

Pennsylvanian; Kentucky ......................... 3.8

Pennsylvanian; Missouri ......................... 4.6

\section{ABUNDANCE IN "NATURAL" UNAMENDED SOILS}

Copper in soils occurs principally as the $\mathrm{Cu}^{+2}$ ion absorbed by clay minerals and in the organic matter where it is very tightly held. Smaller amounts of neutral insoluble salts, water-soluble compounds, and copper minerals may also be present.

\section{ABUNDANCE IN SOILS}

"Representative" analysis of agricultural soils, 50 ppm; range, 5-150 ppm.

In 1,140 samples (10 from each Missouri county), of the surface horizon of agricultural soils, 14 ppm; range, 5-150 ppm.

Average, all U.S. soils, 25 ppm.

Average, Eastern U.S. soils, $21 \mathrm{ppm}$.

Average, Western U.S. soils, $26 \mathrm{ppm}$. 
Copper-Continued

ABUNDANCE IN SOILS-Continued

Distribution of concentrations in U.S. surficial materials was given by Shacklette and Boerngen (1984). Concentrations in many cultivated and uncultivated U.S. soils were given by Connor, Shacklette, and others (1975).

\section{ABUNDANCE IN PLANTS}

The concentrations of $\mathrm{Cu}$ are controlled by the genetic characteristics of the species, by the plant organ that is sampled, and by the amount of available $\mathrm{Cu}$ in the soil. A wide variety of species that were sampled at 910 widely distributed localities in the U.S. averaged $124 \mathrm{ppm} \mathrm{Cu}$ in ash, with a range of $5-1,000 \mathrm{ppm}$.

The $\mathrm{Cu}$ content (ppm in ash) of some crop plants follow (Connor, Shacklette, and others, 1975;

Shacklette, Sauer, and Miesch, 1970):

Corn grains, Missouri, 30-220

Soybean seeds, Missouri, 100-300

Beans, snap (pods), Georgia, 30-300

Cabbage leaves, Georgia, $10-300$

Tomato fruits, Georgia, 30-500

Carrot roots, Wisconsin, 20-120

Potato tubers, Wisconsin, 40-150

Examples of $\mathrm{Cu}$ concentrations in forage, hay, and browse plants (geometric mean ppm in ash) follow:

Johnson grass, Missouri floodplain, 107

Bluegrass, Eastern U.S., 107

Western wheatgrass, Western U.S., 50

Alfalfa, Western U.S., 94

Mesquite, Southwestern U.S., 105

The wide range in $\mathrm{Cu}$ given above, even within a species of crop plant, is notable. This range may be related to differences in availability of soil $\mathrm{Cu}$, to climatological factors, or even to genetic differences within a species (varietal). The $\mathrm{Cu}$ deficiency symptoms of crops have been welldefined and provide reliable guides to the necessity for $\mathrm{Cu}$ fertilization. Tissue analysis, in many species, indicate the $\mathrm{Cu}$ status of the plant. Examples of the levels of $\mathrm{Cu}$ (ppm, dry tissue) in crop plants that indicate $\mathrm{Cu}$ deficiency follow:

Apple leaves, 1-4

Orange leaves, 1-10

Red clover leaves and stems, $<5$

Coffee leaves, 3

Currant leaves, 2-4

Grape leaves, 1-5.4

Oats leaves and stems, 2

Peach leaves, 0.13-0.39

Pear leaves, 3.2-6.7

Wheat grains, 1.5
Copper-Continued

ABUNDANCE IN PLANTS-Continued

Concentrations of $\mathrm{Cu}$ in a wide variety of cultivated and native plants were given by Connor, Shacklette, and others (1975).

\section{SOURCES FOR FERTILIZER \\ GEOLOGIC OR OTHER PRINCIPAL SOURCES}

The $\mathrm{Cu}$ material commonly used as fertilizer, copper sulfate $\left(\mathrm{CuSO}_{4} \cdot 5 \mathrm{H}_{2} \mathrm{O} ; 25.5 \% \mathrm{Cu}, 12.8 \%\right.$ $\mathrm{S}$ ), is manufactured from metallic $\mathrm{Cu}$ that is in the trade, so this fertilizer does not have a direct geologic source. Other $\mathrm{Cu}$ fertilizers, including $\mathrm{CuO}, \mathrm{Cu}(\mathrm{OH})_{2}$, and $\mathrm{Cu}$ chelates are sometimes used.

\section{INCIDENTAL GEOLOGIC OR OTHER SOURCES \\ ATMOSPHERIC}

Direct evidence of atmospheric $\mathrm{Cu}$ being utilized by crop plants is not available. However, Spanish moss, an epiphyte that is totally dependent on airborne elements, was found to contain an average of $150 \mathrm{ppm} \mathrm{Cu}$ in ash (an amount within the "normal" range of crop plants); furthermore, concentrations showed positive correlation with distance from sources of atmospheric $\mathrm{Cu}$ pollution. It seems likely that crop plants utilize some airborne $\mathrm{Cu}$ if in an area of heavy pollution.

\section{IRRIGATION WATER}

Most irrigation waters carry too little $\mathrm{Cu}$ to be of significance in correcting $\mathrm{Cu}$ deficiencies, and the alkalinizing effect of irrigation waters on soils may reduce copper availability and bring on deficiencies.

\section{ORGANIC}

Farm manures, general range, 0.01-0.03 $\mathrm{lbs} /$ ton (0.005-0.015 kg/metric ton), wet weight basis.

Fresh animal manures, average, $15.6 \mathrm{ppm}$ (dry weight basis).

Sewage sludge, Chicago, $0.45 \mathrm{~kg} /$ metric ton $(0.9$ $\mathrm{lb} /$ English ton), dry weight basis.

Plant refuse returned to the soil replaces some the $\mathrm{Cu}$ that was removed from the soil by the crop.

The use of $\mathrm{Cu}$-containing sprays as fungicides, especially Bordeaux mixture (copper sulfate and lime), has greatly increased the $\mathrm{Cu}$ content of old orchard soils to as much as $300 \mathrm{ppm}$. 
Copper-Continued

INCIDENTAL GEOLOGIC-Continued

These sprays have largely been replaced by organic fungicides.

REACTIONS WITH SOIL CONSTITUENTS

$\mathrm{Cu}$ availability is strongly controlled by soil $\mathrm{pH}$. At low $\mathrm{pH}, \mathrm{Cu}$ may reach toxic levels, but as the $\mathrm{pH}$ rises, the availability declines to a satisfactory nutritional level at about $\mathrm{pH} \mathrm{7}$; above this $\mathrm{pH}$ value, availability greatly declines to the point of deficiency for plants. Throughout these changes, total $\mathrm{Cu}$ in the soil can remain at approximately the same level. $\mathrm{Cu}$ retention in soils increases as organic matter increases because of $\mathrm{Cu}$-humus complexing. In some soils the $\mathrm{Cu}$ is retained so tightly that it is not available to plants; in others, plants can absorb $\mathrm{Cu}$ from these complexes. As the organic $\mathrm{N}$ or $\mathrm{S}$ content of organic soils (in one example, peat) increased, the number of stable $\mathrm{Cu}$-organic complexes was found to increase. High $\mathrm{Al}$ concentrations in soil solutions are thought to decrease $\mathrm{Cu}$ uptake by plants. Some experiments have shown that maximum growth of certain crop plants is controlled more by the $\mathrm{Cu}$ :Fe ratio than by the amounts of either element separately, and that the best ratio was 2.5:3.0. It is certain that excessive amounts of $\mathrm{Cu}$ depress the activity of $\mathrm{Fe}$, and this may lead to Fe-deficiency symptoms in plants. High rates of $\mathrm{N}$ fertilizer can cause $\mathrm{Cu}$ deficiencies both by increasing the degree of organic complexing, and by removal of more $\mathrm{Cu}$ in crop plants because of the higher yields promoted by $\mathrm{N}$. High $\mathrm{Cu}$ levels in soils diminish the ability of plants to utilize $P$.

FORMS USED BY PLANTS

$\mathrm{Cu}$ is absorbed from the soil solution as $\mathrm{Cu}^{+2}$ ions, or through the leaves as a $\mathrm{Cu}$ salt on organic complexes, such as EDTA. If the soil is well aerated, ions of higher valence tend to predominate. If drainage is poor, reductions may occur and the low-valence forms will be present.

FUNCTIONS IN PLANT METABOLISM

$\mathrm{Cu}$ is the activator of several enzymes, including tyrosinase, laccase, and ascorbic acid oxidase. It probably is one of the metals involved in the light reaction of photosynthesis-one obvious $\mathrm{Cu}$-deficiency symptom is chlorosis. Secondary influences of $\mathrm{Cu}$ on plant metabolism have not been satisfactorily explained.

\section{EXTENT OF USE}

The amount of $\mathrm{Cu}$ (expressed on an elemental basis) sold for fertilizer in the U.S. in 1969-70 was 772 metric tons (851 English tons). $\mathrm{Cu}$ fertilizers can be applied directly to soil, or can be sprayed on plant leaves. Copper sulfate
Copper-Continued

FORMS USED BY PLANTS-Continued

is commonly used for both methods of application. Copper ammonium phosphate is likewise used, is slowly available in soils, and is only slightly soluble in water but can be suspended in water and sprayed. Cu salts are also produced in frits, which makes the $\mathrm{Cu}$ slowly available, therefore is absorbed by plants over a period of time rather than entering into insoluble forms on clays or in organic complexes. $\mathrm{Cu}$ may also be chelated, and in this form it is soluble but only slightly ionizes, so it does not readily go to unavailable forms in the soil.

Most $\mathrm{Cu}$-deficient soils respond readily to $\mathrm{Cu}$ fertilization. On mineral soils, one application of $5-25 \mathrm{lb} /$ acre $(5.6-28 \mathrm{~kg} / \mathrm{ha})$ copper sulfate is usually sufficient for pastures and field crops. Organic soils may require the addition of 50-200 lb/acre (56-224 kg/ha) of copper sulfate for vegetable and field crops. On muck soils in Michigan, an initial application of $\mathbf{1 0 0}$ $\mathrm{lb} /$ acre $(112 \mathrm{~kg} / \mathrm{ha})$ copper sulfate is recommended, followed by annual applications of lesser amounts until a total of $250 \mathrm{lb} / \mathrm{acre}$ $(2780 \mathrm{~kg} / \mathrm{ha}) \mathrm{has}$ been applied. This treatment provides adequate $\mathrm{Cu}$ for many years.

The $\mathrm{Cu}$ applied to most soils is not subject to leaching, being tightly held in clays and organic matter. The amount removed in crops is extremely small compared to the amounts used as fertilizers-for example, with citrus fruits about 30 years of heavy cropping are required to remove $1 \mathrm{lb} /$ acre $(1.12 \mathrm{~kg} / \mathrm{ha})$ from the soil by harvesting the fruit.

Some general rates of copper sulfate applications follow:

Apple, $1 / 2 \mathrm{lb}(0.22 \mathrm{~kg})$ per tree to soil, or a $0.05 \%$ foliar spray.

Cereal crops, 21/2-10 lb/acre (2.8-11.2 kg/ha).

Hay crops, $25 \mathrm{lb} / \mathrm{acre}(28 \mathrm{~kg} / \mathrm{ha})$.

Corn and cowpeas, $30 \mathrm{lb} / \mathrm{acre}(33.5 \mathrm{~kg} / \mathrm{ha})$ on raw peat soils.

Pasture plants, $5 \mathrm{lb} /$ acre $(5.6 \mathrm{~kg} / \mathrm{ha})$.

\section{SOILS WHERE DEFICIENCIES ARE MOST COMMON \\ Peat and muck soils (unavailable).}

Alkaline and calcareous soils (unavailable).

Leached sandy soils (excessive removal). 
Copper-Continued

SOILS WHERE DEFICIENCIES-Continued

Old corrals and feedlots (excessive $\mathrm{N}$ ).

Soils heavily fertilized with $\mathbf{N}$.

Regions of the U.S. where $\mathrm{Cu}$ deficiencies have been reported to occur in a few to many crop plants are the Atlantic Coastal Plain, the Great Lakes region, California, and parts of the Pacific Northwest.

IRON-(Fe)

\section{OCCURRENCE IN NATURAL MATERIALS} ABUNDANCE IN SELECTED ROCKS

From Connor, Shacklette, and others (1975), in parts per million (ppm)

Granite, Precambrian; Missouri. 1.9

Rhyolite, Precambrian; Missouri. 1.9

Arkose, Fountain Formation; Colorado... .9 Sandstone

Roubidoux Formation; Missouri........... $\quad .17$

Pope Megagroup; Kentucky................... 1.3

Pennsylvanian; Kentucky ........................ 2.0

Pennsylvarian; Missouri .......................... 2.3

Shale

Lower Mississippian; Kentucky ............. 4.2

Upper Mississippian; Kentucky ............. 4.6

Mississippian; Missouri............................ 2.0

Pennsylvanian; Kentucky ........................ 5.4

Pennsylvanian; Missouri .......................... 4.1

Black shale

Devonian and Mississippian; Kentucky. 3.6

Limestone and dolomite

Sauk sequence; Western U.S.................. 1.1

Sauk sequence; Missouri .......................... . .23

Upper Ordovician; Kentucky ................. 1.1

Tippecanoe sequence; Missouri ............ $\quad .17$

Lower Mississippian; Kentucky .............. . .75

Upper Missippippian; Kentucky............ . .55

Mississippian; Missouri............................ . .34

Pennsylvanian; Kentucky ........................ 2.4

Pennsylvanian; Missouri ......................... 1.4

\section{ABUNDANCE IN "NATURAL" UNAMENDED SOILS}

Most of the $\mathrm{Fe}$ occurs in primary minerals, clays, oxides, and hydroxides. Both $\mathrm{Fe}^{+2}$ and $\mathrm{Fe}^{+3}$ forms are found in minerals, although the $\mathrm{Fe}^{+3}$ form predominates in all well-drained soils. Transformations occur with changes in the $\mathrm{O}_{2}$ supply in soils. Amounts of extractable $\mathrm{Fe}^{+2}$ and $\mathrm{Fe}^{+3}$ forms of $\mathrm{Fe}$ are very sensitive to changes in
Copper-Continued

ABUNDANCE IN "NATURAL"-Continued the redox potential of the soil due to submergence. The $\mathrm{Fe}^{+3}$ ions predominate at potentials $>200 \mathrm{mv}$, while the amount of $\mathrm{Fe}^{+2}$ increases rapidly at potentials below this value.

\section{ABUNDANCE IN SOILS}

"Representative" analysis of agricultural soils, 2.5\%; range, $0.5-5 \%$.

In 1,140 samples (10 from each Missouri county), of the surface horizon of agricultural soils, $2.1 \%$; range, $0.5-5.4 \%$.

Average, all U.S. soils, $2.5 \%$.

Average, Eastern U.S. soils, $2.5 \%$.

Average, Western U.S. soils, $2.4 \%$.

Distribution of concentrations in U.S. surficial materials was given by Shacklette and Boerngen (1984). Concentrations in many cultivated and uncultivated U.S. soils were given by Connor, Shacklette, and others (1975).

\section{ABUNDANCE IN PLANTS}

Total Fe content of soils is of little usefulness in predicting soil deficiency for plants. Most soils are abundantly supplied with $\mathrm{Fe}$, but only a small part of it exists in a form that can be absorbed by plants. There is a strong genetic control on iron absorption that varies greatly among plant species. Fe tends to be concentrated in seeds and grains, and to a lesser extent in fruits, rather than in leaves, stems, or roots. Examples of Fe contents of vegetables (geometric mean percent of ash weight) follow:

Lima bean seeds, central Georgia, 0.11

Soybean seeds, unglaciated prairie, Missouri, 0.13

Corn grains, Missouri floodplains, 0.17

Sweet pepper fruits, Wisconsin, 0.16

Cabbage leaves, central Georgia, 0.071

Onion bulbs, Wisconsin, 0.094

Potato tubers, Wisconsin, 0.16

There is a strong tendency for perennial plants, especially trees and shrubs, to accumulate more 
Iron-Continued

ABUNDANCE IN PLANTS-Continued

Fe than do the annual field crops, as illustrated by the following analyses (geometric mean percent of ash weight):

Red maple leaves, northern Georgia, 0.28

Red maple stems, northern Georgia, 0.14

Willow oak stems, Missouri floodplain, 0.25

Red cedar (juniper) stems and leaves, glaciated prairie, Missouri, 0.72

Shortleaf pine stems and leaves, Missouri, 0.52

Examples of concentrations in forage, hay, and browse plants (geometric mean percent in ash) follow:

Johnson grass, Missouri floodplain, 0.19

Big bluestem grass, Missouri glaciated prairie, 0.24

Kentucky bluegrass, Eastern U.S., 0.19

Western wheatgrass, Western U.S., 0.48

Alfalfa, Western U.S., 0.19

Mesquite, Southwestern U.S., 0.36

Concentrations of $\mathrm{Fe}$ in a wide variety of cultivated and native plants were given by Connor, Shacklette, and others (1975).

\section{SOURCES FOR FERTILIZERS}

\section{GEOLOGIC OR OTHER PRINCIPAL} SOURCES

There is seldom an absolute deficiency of $\mathrm{Fe}$ in agricultural soils, only a deficiency in available amounts. This deficiency commonly is corrected by the application of iron sulfate $\left(\mathrm{FeSO}_{4} \cdot 7 \mathrm{H}_{2} \mathrm{O}\right)$. This compound is not very efficient if applied to soils because it rapidly oxidizes in the soil to ferric ion, $\mathrm{Fe}^{+3}$, a form of low availability to plants. If applied as a foliar spray, the effectiveness is greatly increased; therefore, only small amounts are required to correct deficiencies. However, there is very little residual effect of foliar sprays, so repeated applications may be necessary, at least from crop to crop.

Iron sulfate can be injected as dry salt into trunks and limbs of fruit trees, or painted on cut surfaces that result from tree pruning. These treatments are very effective, but care is necessary to avoid toxic concentrations in the tissues.

Iron chelates are the next most widely used $\mathrm{Fe}$ fertilizer, and contain from 6-12\% Fe. Several chelating agents are used, and the chelated $\mathrm{Fe}$ is water soluble but non-ionizing, therefore, remaining in an available form in the soil. A comparison of chelated iron and iron sulfate
Iron-Continued

GEOLOGIC OR OTHER-Continued

applications illustrates the economy in using the higher priced (per pound) chelate:

To correct the Fe-deficiency symptoms of citrus trees in Florida by soil applications, 2,500 lb $(1,135 \mathrm{~kg})$ of ferrous sulfate per tree or $10-50 \mathrm{~g}$ $(0.35-1.75 \mathrm{oz}$.) of a chelated Fe compound per tree was required.

Fritted ferrous iron is satisfactory for use on acid soils where slow release is wanted, but it is not for use on alkaline or calcareous soils.

\section{INCIDENTAL GEOLOGIC OR OTHER SOURCES}

Because availability, not total amount, of $\mathrm{Fe}$ is related to deficiency problems, natural or byproduct materials (although commonly containing considerable $\mathrm{Fe}$ ) cannot contribute materially to correcting $\mathrm{Fe}$ deficiencies. Fe compounds carried in by wind, rain, or irrigation water contain $\mathbf{F e}$ largely in the ferric state, which is already abundant in deficient soils, but is largely unavailable to the plants.

\section{REACTIONS WITH SOIL CONSTITUENTS}

The importance of oxidation-reduction reactions in changing the ionized state of $\mathrm{Fe}$ was discussed earlier. The conversion of soil $P$ to an available form is largely dependent on reduction of $\mathrm{Fe}^{+3}$ compounds and accounts for the high levels of $P$ usually found in submerged soils. The solubility of $\mathrm{Fe}$ is also related to $\mathrm{pH}$, being much greater in acid than in alkaline soils. The stability of $\mathrm{Fe}$ chelates in soil is also related to $\mathrm{pH}$. Above $\mathrm{pH}$ 7.0, FeEDTA is unstable, and $\mathrm{Ca}$ is substituted for $\mathrm{Fe}$. Then, the released $\mathrm{Fe}$ reacts with the soil to form insoluble products.

With competition from $\mathrm{Zn}$, less $\mathrm{Fe}$ is complexed with chelates. Translocation of $\mathrm{Fe}$ from roots to leaves of certain crop plants is reduced if $\mathrm{HCO}_{3}{ }^{-1}$ ions are in the nutrient solution; this reaction is not completely understood. Reaction of $\mathrm{Fe}$ with Mo, as occurs in lateritic soils (oxisol), prevents leaching of Mo. In acid soils, Fe reacts with $\mathrm{P}$ fertilizers to form complex products which are relatively insoluble. High $\mathrm{Mn}$ concentrations in plants may induce $\mathrm{Fe}$ deficiency.

\section{FORMS USED BY PLANTS}

Although ferric iron may be absorbed by plants, the metabolically active form is ferrous $\left(\mathrm{Fe}^{+2}\right)$. $\mathrm{Fe}$ can be absorbed from iron sulfate or $\mathrm{Fe}$ chelates applied as a spray to leaves.

FUNCTIONS IN PLANT METABOLISM

Fe acts as an electron carrier in enzyme systems which bring about oxidation-reduction reactions in plants that are necessary for plant 
Iron-Continued

FORMS USED BY PLANTS-Continued

development and reproduction. $\mathrm{Fe}$ is essential in chlorophyll formation, although not a constituent of chlorophyll, and also is essential for the synthesis of proteins contained in the chloroplasts. The principal symptom of $\mathrm{Fe}$ deficiency is chlorosis-the lack of chlorophyll in tissues that normally are green.

\section{EXTENT OF USE}

The amount of $\mathrm{Fe}$ (expressed on an elemental basis) sold for fertilizer in the U.S. in 1969-70 was 3,259 metric tons (3,591 English tons). Adequate amounts of $\mathrm{Fe}$ in an available form usually are present in acid soils. Fe deficiencies in alkaline soils theoretically could be corrected by acidifying the soils, thereby making adequate amounts of Fe available to plants, but the cost would be prohibitive for field crops. For example, 10 tons ( 9.07 metric tons) of sulfuric acid per acre-foot $\left(1,233.6 \mathrm{~m}^{3}\right)$ of soil would be required for each percent of calcium carbonate present. Soil acidification is practical only for some horticultural plants of high unit value.The problem in $\mathrm{Fe}$ fertilization is in applying and keeping the $\mathrm{Fe}$ in an available state until it is absorbed by plants. For this reason, soluble Fe salts are used mostly in foliar or injection, rather than in soil, applications. Fe chelates may be applied to both soils and leaves.

Examples of application rates and methods follow:

Fe chelates, soil application

Vegetables and flowers, $1 \mathrm{oz} / 100 \mathrm{ft}$ of row $(9.3 \mathrm{~g} / \mathrm{m})$.

Shrubs and small trees, $1 / 4-2$ oz/tree (0.11$0.45 \mathrm{~kg} /$ tree).

Large trees, $\quad 1 / 4-1 \quad \mathrm{lb} /$ tree $\quad(0.11-0.45$

$\mathrm{kg} /$ tree).

Potted plants, $1 / 4-1$ teaspoonful.

Lawns, $1 \mathrm{oz} / 100 \mathrm{ft}^{2}\left(100 \mathrm{~g} / \mathrm{m}^{2}\right)$.

Citrus trees, $10-20 \mathrm{~g} /$ tree $(0.35-0.70$

oz/tree).

Fe chelates, spray application

Flax, $8 \mathrm{lb} / 100$ gallons $(9.5 \mathrm{~g} / 100 \mathrm{l})$ water

Fe salts, injection

Citrus, ferric citrate placed in holes in trees, or ferrous sulfate, $50-100 \mathrm{~g} / 1-2$ gallons (13-26 g/11-22 l) water, injected into tree trunks and limbs at 50-100 psi (3.44-6.89 bars).

Apple, ferric phosphate placed in holes bored into trunks.
Iron-Continued

FORMS USED BY PLANTS-Continued

Fe salts, soil application

Rice, broadcast applications of 50-1,000

$\mathrm{lb} /$ acre $(560-1,120 \mathrm{~kg} / \mathrm{ha})$ ferric sulfate before planting.

Fe salts, spray application

Sorghum, $4 \%$ ferrous sulfate, applied at the rate of 30 gallons/acre ( $284 \mathrm{l} / \mathrm{ha}$ ).

Magnetite $\left(\mathrm{Fe}^{+2} \mathrm{Fe}_{2}^{+3} \mathrm{O}_{4}\right.$ )

In an experiment with $\mathrm{Fe}$-deficient citrus trees, soil applications of finely powdered magnetite were found to be an excellent source of $\mathrm{Fe}$, even in an alkaline nutrient solution. Rates of application not given.

\section{SOILS WHERE DEFICIENCIES ARE MOST COMMON}

Calcareous soils.

Poorly drained soils.

Manganiferous soils.

Areas of Fe deficiency in soils for specific crops are widespread in the U.S., but most occur in the western states where soils tend to be on the alkaline side of neutral.

\section{MANGANESE-(Mn)}

\section{OCCURRENCE IN NATURAL MATERIALS}

ABUNDANCE IN SELECTED ROCKS

From Connor, Shacklette, and others (1975), in parts per million (ppm)

Granite, Precambrian; Missouri .................. 377

Rhyolite, Precambrian; Missouri.................... 464

Arkose, Fountain formation; Colorado..... 336

Sandstone

Sauk sequence; Western U.S.................. 252

Roubidoux Formation; Missouri............ 58

Pope Megagroup; Kentucky..................... 244

Pennsylvanian; Kentucky ......................... 240

Pennsylvanian; Missouri ........................... 870

Shale

Sauk sequence; Western U.S.................. 546

Lower Mississippian; Kentucky ............... 219

Upper Mississippian; Kentucky ............... 195

Mississippian; Missouri.............................. 175

Pennsylvanian; Kentucky .......................... 324

Pennsylvanian; Missouri ............................ 208

Black shale

Devonian and Mississippian; Kentucky... 80

Limestone and dolomite

Sauk sequence; Western U.S................... 624

Sauk sequence; Missouri .......................... 145

Upper Ordovician; Kentucky .................... 598

Tippecanoe sequence; Missouri .............. 165

Lower Mississippian; Kentucky ............... 256 
Manganese-Continued

ABUNDANCE IN SELECTED-Continued

Limestone and dolomite-Continued Upper Missippippian; Kentucky.......... 196

Mississippian; Missouri.......................... 192

Pennsylvanian; Kentucky ....................... 1,001

Pennsylvanian; Missouri ........................ 1,162

\section{ABUNDANCE IN "NATURAL" UNAMENDED SOILS}

The usual forms of $\mathrm{Mn}$ that occur in soils are various oxides and hydroxides, with pyrolusite, hausmannite, and mannite being the most common Mn-bearing minerals. Only a small fraction of the total $\mathrm{Mn}$ is in the reduced divalent form that is unavailable to plants.

\section{ABUNDANCE IN SOILS}

"Representative" analysis of agricultural soils, 2,500 ppm; range 200-10,000.

In 1,140 samples (10 from each Missouri county) of the surface horizon of agricultural soils, 851 ppm; range, 15-3,000 ppm.

Average, all U.S. soils, 560 ppm.

Average, Eastern U.S. soils, 656 ppm.

Average, Western U.S. soils, 467 ppm.

Distribution of concentrations in U.S. surficial materials was given by Shacklette and Boerngen (1984). Concentrations in many cultivated and uncultivated U.S. soils were given by Connor, Shacklette, and others (1975).

\section{ABUNDANCE IN PLANTS}

Total Mn content of soils is of little usefulness in predicting soil deficiency for plants. Most soils are abundantly supplied with $\mathrm{Mn}$ in relation to plant requirements, but only a small part of it exists in the divalent form available to plants.

There is a striking difference in the $\mathrm{Mn}$ concentrations in ash of annual herbaceous plants, including field crops, and in the leaves and stems of perennial woody plants (trees and shrubs). The reason for this difference is not clear but may be caused by the deeper root penetration and greater age of the trees and shrubs. Examples of the relatively low concentrations of $\mathrm{Mn}$ in some crop plants (geometric mean ppm in ash) follow:

Lima bean seeds, central Georgia, 320

Soybean seeds, unglaciated prairie, Missouri, 310

Corn grains, unglaciated prairie, Missouri, 320

Sweet pepper fruits, Wisconsin, 200

Cabbage leaves, Wisconsin, 220
Manganese-Continued

ABUNDANCE IN PLANTS-Continued

Carrot roots, Wisconsin, 96

Potato tubers, Wisconsin, 110

The Mn content of trees is illustrated by the examples that follow (geometric mean $\mathrm{ppm}$ in ash):

Red maple leaves, northern Georgia, 6,700

Red maple stems, northern Georgia, 6,800

White oak stems, Kentucky, 13,000

Red cedar (juniper) stems and leaves, glaciated prairie, Missouri, 4,800

Shortleaf pine stems and leaves, Missouri, 14,000

Examples of $\mathrm{Mn}$ concentrations in forage, hay, and browse plants (geometric mean ppm in ash) follow:

Johnson grass, Missouri floodplain, 553

Kentucky bluegrass, Eastern U.S., 580

Western wheatgrass, Western U.S., 530

Alfalfa, Western U.S., 250

Mesquite, Southwestern U.S., 383

Concentrations of $\mathrm{Mn}$ in a wide variety of cultivated and native plants were given by Connor, Shacklette, and others (1975).

\section{SOURCES FOR FERTILIZERS \\ GEOLOGIC OR OTHER PRINCIPAL SOURCES}

Manganese sulfate, $\mathrm{MnSO}_{4}$, has long been the principal Mn fertilizer, the commercial grade containing about $26 \% \mathrm{Mn}$ and $15 \% \mathrm{~S}$. A manganese ammonium phosphate fertilizer is available in both a chelated and a fritted form. A more recent product is manganese oxide, which is water-insoluble, but is slightly soluble in dilute acids.

\section{INCIDENTAL GEOLOGIC OR OTHER} SOURCES

Farm manures vary in Mn content, depending on kind of animal, the feed used, and the bedding provided the animal. A general range given for $\mathrm{Mn}$ is $0.01-0.18 \mathrm{lb} /$ ton (4-800 g/metric ton). At the usual application rates for manure, these amounts of $\mathrm{Mn}$ are inadequate for correcting $\mathrm{Mn}$ deficiencies.

The $\mathrm{Mn}$ in dry sewage sludge is reported to range from $0.2-1.35 \mathrm{~kg} /$ metric ton $(0.44-3 \mathrm{lb} /$ English ton).

\section{REACTIONS WITH SOIL CONSTITUENTS}

$\mathrm{Mn}$ in the soil is considered to exist in three valence states: (1) divalent $\mathrm{Mn}^{+2}$, which is present as an adsorbed cation or is in the soil solution; (2) trivalent $\mathrm{Mn}^{+3}$, thought to exist as the highly reactive oxide $\mathrm{Mn}_{2} \mathrm{O}_{3}$; and (3) tetrava- 


\section{Manganese-Continued}

REACTIONS WITH SOIL-Continued

lent $\mathrm{Mn}^{+4}$, which exists as the very inert oxide

$\mathrm{MnO}_{2}$. The form most likely to occur at $\mathrm{pH}$ values greater than 8.0 is $\mathrm{MnO}_{2}$; the trivalent form occurs at $\mathrm{pH}$ values near 7 , and the divalent form at lower $\mathrm{pH}$ values. Therefore, acid soils commonly have sufficient soluble $\mathrm{Mn}$ for plant requirements. Only in some very sandy soils in regions of high rainfall does $\mathrm{Mn}$ occur in amounts inadequate to meet plant needs.

If soluble $\mathrm{Mn}$ fertilizers, such as $\mathrm{MnSO}_{4}$, are applied to alkaline soils, the $\mathrm{Mn}$ rapidly turns into an insoluble form; this can be reduced or prevented by mixing the $\mathrm{Mn}$ fertilizer with an acid-forming fertilizer, such as superphosphate. Finely ground elemental $\mathrm{S}$ may be applied at the same time as the Mn fertilizer, which will create a temporary lowering of $\mathrm{pH}$ and permit plants to absorb the Mn while it is still soluble.

Excessive amounts of available Mn may be present in extremely acid soils, leading to $\mathrm{Mn}$ toxicity for many plant species. This condition is usually corrected by liming, or by management practices, such as draining, which will reduce the soil acidity.

Mn fertilizers may be applied in the fritted form, in which the $\mathrm{Mn}$ is slowly released to the soil solution and can be absorbed by plant roots before it is oxidized to insoluble forms. The chelated form, MnEDTA, is usually unsatisfactory as a fertilizer, as it often reduces crop yields. The reason for this is not clear but may be related to displacement of the $\mathrm{Mn}$ in the chelate by other cations, since the stability constant of MnEDTA is relatively low.

Because of the problems associated with soil applications, $\mathrm{Mn}$ is often applied as a foliar spray as $\mathrm{MnSO}_{4}$.

\section{FORMS USED BY PLANTS}

Only the soluble divalent $\mathrm{Mn}^{+2}$, or in molecular combinations with certain organic complexing agents.

\section{FUNCTIONS IN PLANT METABOLISM}

Mn functions in the activation of numerous enzymes concerned with carbohydrate metabolism, phosphorylation reactions, and the citric acid cycle and with other metals in the activation of the enzymes arginase, cysteine desulfhydrase, deoxyribonuclease, and yeast
Manganese-Continued

FORMS USED BY PLANTS-Continued

phosphatase. It is thought to be a specific activator of the enzymes prolidase and glutamyl transferase. It is also thought to function in certain photosynthetic processes.

\section{EXTENT OF USE}

The amount of Mn (expressed on an elemental basis) sold for fertilizers in the U.S. in 1969-70 was 12,155 metric tons (13,395 English tons).

Many areas of Mn deficiency for various kinds of crops have been reported in the U.S. However, these deficiencies are not corrected by applications of $\mathrm{Mn}$ fertilizers alone, but also by management practices that increase the supply of available $\mathrm{Mn}$ in soils that already have abundant total Mn. Moreover, the susceptibility to $\mathrm{Mn}$ deficiency in the soil varies widely among different crop plants so it may be more practical to grow crops that can tolerate a degree of soil deficiency than to change the available supply in the soil.

To correct Mn deficiencies of soils, a general recommendation is to apply $30-60 \mathrm{lb} / \mathrm{acre} / \mathrm{yr}$ $(33.6-67.2 \mathrm{~kg} / \mathrm{ha} / \mathrm{yr})$ manganese sulfate in the "starter" fertilizer.

When deficiency symptoms in plants have developed, it is too late for soil applications to be effective in correcting the deficiency. However, foliar applications can reduce the deficiency symptoms very rapidly. The crops are sprayed with 5-10 lb $(2.3-4.5 \quad \mathrm{~kg})$ manganese sulfate in 100 gallons (378.4 l) water per acre ( $0.41 \mathrm{ha})$.

\section{SOILS WHERE DEFICIENCIES ARE MOST COMMON}

Thin, peaty soils overlying calcareous subsoils.

Alluvial soils and marsh soils derived from calcareous materials.

Poorly drained calcareous soils with a high content of organic matter.

Calcareous black sands and reclaimed acid heath soils.

Old black garden soils where manure and lime have been applied regularly for many years. Very sandy acid mineral soils that are low in native Mn content. 
MOLYBDENUM-(MO)

OCCURRENCE IN NATURAL MATERIALS

ABUNDANCE IN SELECTED ROCKS

From Connor, Shacklette, and others (1975), in parts per million (ppm)

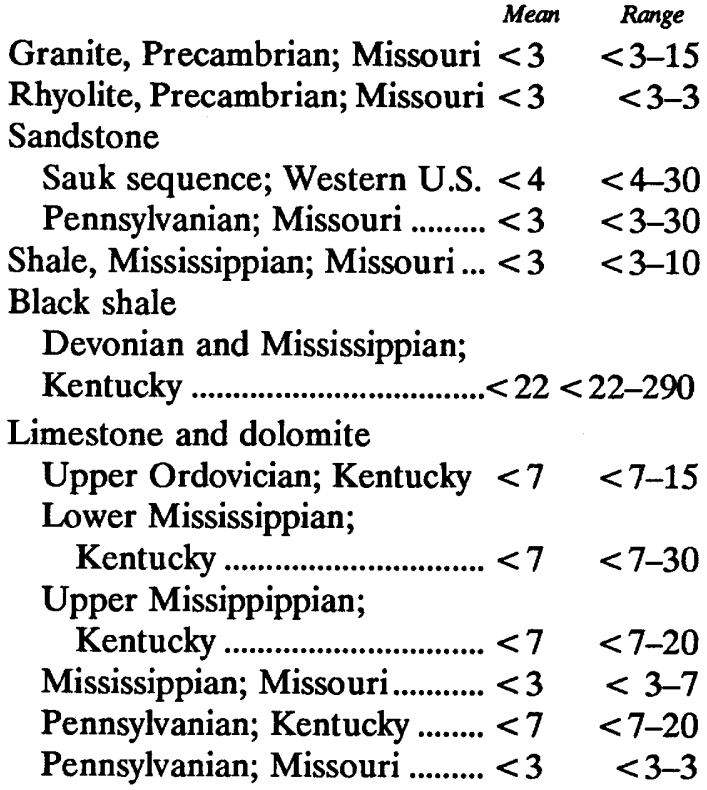

\section{ABUNDANCE IN "NATURAL" UNAMENDED} SOILS

MINERALS

Most of the Mo in soils occurs either within the crystal lattice of primary and secondary minerals, or as an exchangeable ion. Significant amounts of $\mathrm{Mo}$ as $\mathrm{MoO}_{4}^{-2}$ react with hydrous oxides of $\mathrm{Fe}$ and $\mathrm{Al}$ in soils. Apparently, molybdenite (molybdenum sulfide) is rare in soils.

\section{ORGANICS}

Although no references have been found giving the Mo content of organic matter in "natural" soil, the Mo content of the ash of vegetation generally is considerably higher than the concentration in rocks or soil. It is reasonable, therefore, to assume that the Mo in natural plant residues makes a significant contribution to the Mo requirement of soil micro-organisms and higher plants.

\section{ABUNDANCE IN SOILS}

"Representative" analysis of agricultural soils: 2 ppm; range, 0.2-5 ppm.

In 1,140 samples (10 from each Missouri county) of the surface horizon of agricultural soils, Mo was found in only 16 samples in concentrations of $3 \mathrm{ppm}$ (the lower limit of determination of the analytical method used) or greater; the values ranged from $<3-15 \mathrm{ppm}$.
Molybdenum-Continued

ABUNDANCE IN SOILS-Continued

In 844 samples of $B$-horizon soil from throughout the conterminous U.S., the Mo concentration exceeded $3 \mathrm{ppm}$ in only $9 \%$ of the samples, and ranged from $<3-7 \mathrm{ppm}$.

Distribution of concentrations in U.S. surficial materials was given by Shacklette and Boerngen (1984). Concentrations in many cultivated and uncultivated U.S. soils were given by Connor, Shacklette, and others (1975).

\section{ABUNDANCE IN PLANTS}

Mo, as a component of plant ash, tends to be concentrated in seeds and grain, rather than in the vegetative parts of plants. Herbaceous plants generally have greater concentrations in their stems and leaves than have trees and shrubs. Examples of Mo concentrations (geometric mean ppm in ash) in some crop plants follow:

Lima bean seeds, central Georgia, 9.5

Soybean seeds, glaciated prairie, Missouri, 17

Corn grains, Missouri floodplain, 18

Snap bean pods (fruit), central Georgia, 4.7

Cabbage leaves, northern Georgia, $<5.0$

Onion bulbs, Wisconsin, 10

Potato tubers, Wisconsin, 6.6

Examples of Mo concentrations (geometric mean ppm in ash) in stems and leaves of some woody plants follow:

Black gum stems, central Georgia, $<5$

Black gum leaves, central Georgia, $<5$

Buckbush stems, cedar glades, Missouri, 6.5

(range, <5-30)

Black oak stems, Kentucky, 0.76

Red cedar (juniper), cedar glades, Missouri, 7.6

Red cedar (juniper), oak-hickory forest,

Missouri, 1.3

Results of Missouri studies suggest that Mo concentrations in trees and shrubs are greatest in those growing in alkaline soil.

Examples of Mo concentrations in forage, hay, and browse plants (geometric mean percent in ash) follow:

Johnson grass, Missouri floodplain, 6.0

Western wheatgrass, Western U.S., 7.25

Kentucky bluegrass, Eastern U.S., 3.3

Alfalfa, Western U.S., 18

Mesquite, Southwestern U.S., 12.9 
Molybdenum-Continued

SOURCES FOR FERTILIZERS

GEOLOGIC OR OTHER PRINCIPAL SOURCES

Reports indicate that sodium molybdate, ammonium molybdate, and even the less soluble molybdenum trioxide were about equally effective in supplying Mo to plants. Molybdenite $\left(\mathrm{MoS}_{2}\right)$ is not effective as a fertilizer. Western U.S. phosphate rock is reported to contain $60 \mathrm{ppm}$ or less Mo, while Eastern U.S. phosphate rock contains less than $17 \mathrm{ppm}$. However, the $\mathrm{Mo}$ in phosphate fertilizers is not effective in overcoming Mo deficiencies for certain crops.

\section{INCIDENTAL GEOLOGIC OR OTHER SOURCES}

A general range given for Mo in farm manures is $0.001-0.011 \mathrm{lb} /$ ton $(4-40 \mathrm{~g} / \mathrm{metric}$ ton $)$, and if the manure is applied to soil at a high rate, it could correct deficiencies in some soils.

Sewage sludge is reported to contain Mo in the range of 2-118 ppm, with most analyses in the 2-10 ppm range. If not containing certain undesirable elements in excess, this material could be a useful Mo supplement to soils.

\section{REACTIONS WITH SOIL CONSTITUENTS}

The total amount of Mo in soils is much smaller than that of the other plant nutrients, and most of it is unavailable to plants. The Mo held in the crystal lattice of primary and secondary minerals is not available; whereas, the Mo adsorbed on clays, in organic matter, and in soluble compounds is available. Availability increases with soil $\mathrm{pH}$-just the reverse of the reaction of most other soil microelements. A pronounced lime-Mo interaction has been shown for many Mo-deficient soils, and applications of either lime or Mo may increase crop yields, or on some soils, both lime and Mo are required. The presence of oxides of $\mathrm{Fe}, \mathrm{Al}$, and $\mathrm{Ti}$ increase the adsorption of Mo. Heavy applications of sulfate fertilizer depress Mo uptake by plants, thought to result from competition at the root surface for the $\mathrm{MoO}_{4}{ }^{-2}$ and $\mathrm{SO}_{4}{ }^{-2}$ ions, which are of similar size and charge.

\section{FORMS USED BY PLANTS}

Mo is probably absorbed by plant roots as the ion $\mathrm{MoO}_{4}{ }^{-2}$. Leaves can absorb Mo from $\mathrm{Na}_{2} \mathrm{MoO}_{4}$ spray, but the form of Mo entering the tissues is not known.
Molybdenum-Continued

FORMS USED BY PLANTS-Continued

FUNCTIONS IN PLANT METABOLISM

Mo is essential for $\mathbf{N}$ fixation by the nodule bacteria of legumes and is also required by nonlegumes for nitrate reduction. Nitrogen fixation, assimilation, and reduction may all be involved in amino-acid and protein synthesis. A deficiency of Mo results in the accumulation of nitrates in plant tissue and a lowering of the activity of ascorbic acid oxidase. Mo is known to be specific for the activation of the enzymes nitrate reductase and xanthine oxidase.

\section{EXTENT OF USE}

The amount of Mo (expressed on elemental basis) sold for fertilizer in the U.S. in 1969-70 was 62 metric tons (68 English tons).

Mo deficiencies in soils are corrected by the use of Mo fertilizers, or since most soils have sufficient Mo, the application of lime to increase Mo availability may suffice. Mo is required by plants in only small amounts, a point of considerable importance because an excess in the soil may cause plants to accumulate Mo to levels that are toxic to grazing animals. An imbalance of Mo and $\mathrm{Cu}$ in animal metabolism occurs when the forage contains more than $5 \mathrm{ppm}$ (dry weight basis) Mo (Allaway, 1968). The amount of Mo normally present in large seeds may supply sufficient Mo for the plants growing from the seed, even on Mo-deficient soils.

Because of the small amount of Mo required to correct deficiencies, Mo is usually added to lime or fertilizer mixtures for soil application. It may also be applied as a seed treatment or as a foliar spray.

Typical soil applications of Mo range from 1-32 oz/acre (70-2,250 g/ha). A reported effective application of $\mathrm{Mo}$ as $\mathrm{Na}_{2} \mathrm{MoO}_{4}$ was $18-36 \mathrm{~g}$ $\mathrm{Mo} / \mathrm{acre}$ (7.3-14.6 $\mathrm{g} / \mathrm{ha})$. Dilute solutions of $\mathrm{Na}_{2} \mathrm{MoO}_{4}$ may be applied to seeds before sowing, or sprayed on the foliage of crop plants; the methods are equally effective.

\section{SOILS WHERE DEFICIENCIES ARE MOST COMMON}

Highly podzolized soils (low total Mo, unavailability)

Extensively weathered soils (formation of secondary minerals may fix Mo strongly) 
Molybdenum-Continued

SOILS WHERE DEFICIENCIES-Continued

Soils having a pH value below 6.0 (low availability of Mo)

Sandy, well-drained soils low in total Mo

In the U.S., the soils most likely to have Mo deficiencies are the acid sandy soils of the Atlantic and Gulf States.

\section{ZINC-(Zn)}

\section{OCCURRENCE IN NATURAL MATERIALS} ABUNDANCE IN SELECTED ROCKS

From Connor, Shacklette, and others (1975), in parts per million (ppm)

Granite, Precambrian; Missouri.

Rhyolite, Precambrian; Missouri

Sandstone

Sauk sequence; Western U.S................ $<50$

Roubidoux Formation; Missouri............. 5.7

Pennsylvanian; Missouri ............................ 53

Shale

Mississippian; Missouri ................................ 99

Pennsylvanian; Missouri ............................ 86

Limestone and dolomite

Sauk sequence; Missouri ........................... 7.6

Tippecanoe sequence; Missouri ................ 13

Mississippian; Missouri ................................ 21

Pennsylvanian; Missouri ............................. 32

\section{ABUNDANCE IN “NATURAL" UNAMENDED SOILS \\ MINERALS}

$\mathrm{Zn}$ occurs in soils in sulfide, oxide, and silicate minerals. It is adsorbed by various clay minerals and also by the carbonates of $\mathrm{Ca}$ and $\mathrm{Mg}$. $\mathrm{Zn}$ occurs in the soil solution or adsorbed on colloids only in the ionic form $\mathrm{Zn}^{+2}$.

\section{ORGANICS}

Organic matter is an important secondary source of $\mathrm{Zn}$, in which the element is held as complex combinations by the organic colloids. Although when thus held $\mathrm{Zn}$ is not readily available to plants, its release through decomposition of organic matter is an important fertility factor.

\section{ABUNDANCE IN SOILS}

"Representative" analysis of agricultural soils: 100 ppm; range, 10-250 ppm.

In 1,140 samples (10 from each Missouri county) of the surface horizon of agricultural soils, 53 ppm; range, 18-640 ppm.
Molybdenum-Continued Zinc-Continued ABUNDANCE IN SOILS-Continued Average, all U.S. soils, 54 ppm.

Average, Eastern U.S. soils, 43 ppm.

Average, Western U.S. soils, 59 ppm.

Distribution of concentrations in U.S. surficial materials was given by Shacklette and Boerngen (1984). Concentrations in many cultivated and uncultivated U.S. soils were given by Connor, Shacklette, and others (1975).

\section{ABUNDANCE IN PLANTS}

The range in $\mathrm{Zn}$ content in plant tissues is extremely wide and is influenced by kind of plant, plant organ sampled, and concentration of available zinc in the soil. The reported range is $<20-10,200 \mathrm{ppm}$ in dry plant material. $\mathrm{Zn}$, as a component of plant ash, is commonly concentrated in seeds and grains, but concentrations equally high can be found in the woody parts of some trees and shrubs. Examples of $\mathrm{Zn}$ concentrations (geometric mean ppm in ash) in some crop plants follow:

Lima bean seeds, central Georgia, 600

Soybean seeds, glaciated prairie, Missouri, 870

Corn grains, unglaciated prairie, Missouri, 1,900

Snap bean pods (fruit), central Georgia, 530

Cabbage leaves, Wisconsin, 250

Carrot roots, Wisconsin, 180

Onion bulbs, Wisconsin, 330

Potato tubers, Wisconsin, 280

Examples of the $\mathrm{Zn}$ concentrations (geometric mean ppm in ash) in stems and leaves of some woody plants follow:

Black cherry stems, central Georgia, 1,300

Black cherry leaves, central Georgia, 220

Buckbush stems, unglaciated prairie, Missouri, 1,800

Red cedar (juniper) stems and leaves, cedar glades, Missouri, 320

Black oak stems, Kentucky, 540

Shortleaf pine, stems and leaves, Missouri, 1,200

Sassafras stems, northern Georgia, 1,300

Sassafras leaves, northern Georgia, 460

Examples of $\mathrm{Zn}$ concentrations in forage, hay, and browse plants (geometric mean ppm in ash) follow:

Johnson grass, Missouri floodplain, 518

Alfalfa, Western U.S., 223

Mesquite, Southwestern U.S., 440 
Zinc-Continued

SOURCE FOR FERTILIZERS

\section{GEOLOGIC OR OTHER PRINCIPAL} SOURCES

Zinc sulfate, containing about $36 \% \mathrm{Zn}$, has for years been a popular fertilizer material. Zinc ammonium phosphate is useful in that it is only slightly soluble in water, therefore extending the availability of $\mathrm{Zn}$ over a long period of time when applied to soil. The same effect is produced by using $\mathrm{Zn}$ carried in frits or in various chelates, such as ZnEDTA. Zinc oxide is another important fertilizer. More recently, a zinc-ironammonium sulfate compound has been developed by ammoniating spent sulfuric acid containing $\mathrm{Fe}$ and $\mathrm{Zn}$ as impurities.

\section{INCIDENTAL GEOLOGIC OR OTHER SOURCES}

A general $\mathrm{Zn}$ range given for farm manures is 43-247 ppm in dry matter with an average value of $96.2 \mathrm{ppm}$. This $\mathrm{Zn}$ content compares favorably with that of inorganic $\mathrm{Zn}$ fertilizers and, at the application rates generally used for manure, should supply adequate $\mathrm{Zn}$ for crops on most soils.

Dry sewage sludge is reported to contain $\mathrm{Zn}$ in the range of $0.7-3.95 \mathrm{~kg} /$ metric ton $(3.3-18.7 \mathrm{lb} / \mathrm{Engl}-$ ish ton). If it does not contain undesirable elements in excess, this material is a useful $\mathrm{Zn}$ supplement to soils.

Crop residues can return appreciable amounts of $\mathrm{Zn}$ to soils, but the amounts vary widely depending on the kind and condition of the residue.

\section{REACTIONS WITH SOIL CONSTITUENTS}

The plant availability of $\mathrm{Zn}$ is conditioned by several soil factors: $\mathrm{pH}$, phosphorus level, organic matter content, and adsorption by clays. In general, the availability of zinc is a function of soil acidity-most $\mathrm{Zn}$ deficiencies occur with the range of $\mathrm{pH}$ 6.0-8.0. $\mathrm{Zn}$ deficiency on high phosphate soils has been observed frequently, but the nature of the reactions involved is not known. The simple precipitation of zinc phosphate is inadequate to explain this phenomenon, even though the solubility of $\mathrm{Zn}$ decreases at high concentrations of the phosphate ion. Zinc deficiencies have been observed on soils high in organic matter or that have been fertilized with animal manures. The fact that this deficiency can be corrected by soil sterilization suggests that living organisms in the soil immobilize the zinc, but the reactions are unknown. $\mathrm{Zn}$ deficiencies
Zinc-Continued

REACTIONS WITH SOIL-Continued

are commonly observed on calcareous soils, and liming of acid soils may produce the same effect. These effects are explained by the fact that $\mathrm{Zn}$ is adsorbed on calcium and magnesium carbonates in the following decreasing order: Magnesite $\left(\mathrm{MgCO}_{3}\right)$, dolomite $\left(\mathrm{CaMg}\left(\mathrm{CO}_{3}\right)_{2}\right)$, and calcite $\left(\mathrm{CaCO}_{3}\right)$. In magnesite and dolomite, it is thought that the $\mathrm{Zn}$ is actually adsorbed into the crystal surfaces at the sites in the lattice normally occupied by $\mathrm{Mg}$ atoms. $\mathrm{Zn}$ forms many compounds of low solubility in soils by precipitation as carbonates, hydroxides, and phosphates-which reduces the availability to plants. Therefore, from the agronomic standpoint, $\mathrm{Zn}$ is relatively immobile in most soils.

\section{FORMS USED BY PLANTS}

$\mathrm{Zn}$ is absorbed by plant roots as the ion $\mathrm{Zn}^{+2}$ and may also be absorbed as a molecular complex of such chelating agents as EDTA. Zinc is also capable of entering the plant directly through the leaves if applied as a spray of soluble $\mathrm{Zn}$ salts or complexes.

\section{FUNCTIONS IN PLANT METABOLISM}

Zinc functions in plants largely as a metal activator of enzymes including enolase, yeast aldolase, oxalacetic decarboxylase, lecithinase, cysteine desulfhydrase, carbonic anhydrase, and others. Like many of the other micronutrients, $\mathrm{Zn}$ is toxic to plants in any but small quantities. Its concentration in the plants in relation to the other heavy metals is of greater importance than the absolute amounts present.

\section{EXTENT OF USE}

The amount of $\mathrm{Zn}$ (expressed on elemental basis) sold for fertilizer in the U.S. in 1969-70 was 16,444 metric tons (18,084 English tons). A general rate given for the application of zinc sulfate, a popular fertilizer, is $40-80 \mathrm{lb} / \mathrm{acre}$ (46-90 kg/ha). The variable fixation and movement of zinc in soils and the danger from toxicity have been factors which have tended to discourage deficiency corrections by soil applications. In one experiment it was found that mixing $5 \mathrm{lb}(2.27 \mathrm{~kg})$ zinc sulfate and $5 \mathrm{lb}$ $(2.27 \mathrm{~kg})$ calcium chloride and applying in small piles to sandy Florida soils greatly increased zinc uptake by the trees. The Ca appeared to prevent $\mathrm{Zn}$ fixation in the soil.

In general, the preferred method of $\mathrm{Zn}$ application to correct plant deficiencies is as a spray. Some examples of spray applications follow: 
Zinc-Continued

FORMS USED BY PLANTS-Continued

Alfalfa-A $0.5 \%$ zinc sulfate sprayed on young plants effected marked recovery in $\mathbf{1 0}$ days.

Apple trees-Dormant sprays of $25-50 \mathrm{lb}$ $(2.7-5.6 \mathrm{~kg})$ zinc sulfate per 100 gallons (378.4 l) water were found effective.

Red Mexican beans-A $0.3 \%$ zinc sulfate foliar spray applied to plants 4-6 in. $(10.2-15.2 \mathrm{~cm})$ high.

Field corn-A foliar spray composed of $0.5 \%$ zinc sulfate and $0.25 \%$ calcium hydroxide applied to corn 6 in. $(15.2 \mathrm{~cm})$ high.

Zinc fertilizers can be supplied to trees by direct injection, as by boring holes and filling them with the fertilizer, or by driving zinccoated nails or pieces of galvanized iron into the tree, but the amounts of zinc applied and its effectiveness are uncertain and difficult to measure.

\section{SOILS WHERE DEFICIENCIES ARE MOST COMMON}

Acid, leached, sandy soils where total $\mathrm{Zn}$ is low.

Alkaline soils where $\mathrm{Zn}$ availability is decreased.

Soils derived from granites and gneisses.

Some organic soils where $\mathrm{Zn}$ is tied up in forms that are not readily available to plants.

Soils containing clays with low $\mathrm{Si}$ to $\mathrm{Mg}$ ratios. In these, $\mathrm{Zn}$ may be fixed in forms not readily available to plants.

\section{USE OF SOIL AMENDMENTS \\ TO IMPROVE THE \\ PHYSICAL PROPERTIES OF SOIL}

\section{Introduction}

Factors influencing plant growth include moisture, heat, light, and the chemical and physical nature of the substrate (soil). Soil amendments are materials added to soils for the purpose of modifying their chemical and physical properties. This section deals only with physical amendments.
Alterations of the physical properties of a soil will result in responses which cannot be explained in their entirety by a consideration of only the physical action that was taken. The physical, chemical, biological, and microbiological properties of soils are so integrated that an alteration of any single factor will affect each of the other factors. Some of the effects of various soil amendments on the physical properties of soil are given in the discussions that follow. The chemical, biological, and microbiological implications of the physical changes in soils will not be considered.

Physical soil amendments are employed in agricultural practice to create a more favorable environment for plant growth and to aid the conservation of soil. For plant growth, these amendments improve the seed bed to enhance germination and to modify characteristics of the root zone in a manner that improves growth. For soil conservation, physical amendments aggregate the soil particles into stable units so that water infiltration will be maximized, and runoff and soil dispersion will be minimized. The ultimate goal in using these amendments is to match the properties of the soil to the physiological requirements of the plant species that is to be cultivated.

In general, the permanent features of the soil landscape (texture, slope, ground water, flooding, and local climate) are not readily amended, if at all, by the simple addition of some agent. To increase the clay content of the plow zone of an average soil by 1 percent would require the addition of 10 English tons of clay per acre (22.4 metric ton/ha). At present, with the prevailing economics of agricultural production, this would not be economical. Consideration should be given, therefore, to those less permanent features that have the potential to be economically amended, such as soil structure, soil moisture, soil aeration, and soil temperature.

Resources of the various mineral soil amendments in the United States appear to be adequate to meet the present demand, which is largely restricted to the horticultural industry, and here the demand is relatively small. Commercial mechanized agriculture is using energy expended by heavy tillage machinery to maintain desirable physical properties of soils in place of using mineral or other physical amendments. At present, the use of "energy" is an economical way to amend soils, compared to the cost of mining, transporting, and applying mineral soil amendments.

The mineral soil amendments have not received sufficient attention in experimental field trials to demonstrate their benefits and justify their use in commercial food production. The present trend, in general, is to select species, or develop varieties by genetic modification that can withstand the more unfavorable "permanent" soil conditions rather than to modify these conditions to meet the requirements of a 
particular species. Interest in the use of soil amendments should increase as energy sources become more expensive, as soil resources become more limiting, as expanding populations demand more agricultural production from a finite resource (the soil), and as lands presently considered marginal for agriculture are brought into production.

In areas of the world where agriculture is more "people intensive" than "power intensive," soil amendments may play a significant role in increasing agricultural production. In these agricultural areas, the soil amendments should have a local geologic source because the availability of and cost of transportation is a limiting factor in the utilization of these materials.

In the following discussion, the physical amendments are divided into three groups: (1) mineral materials, (2) organic materials, and (3) miscellaneous materials.

\section{Mineral Materials}

\section{CLAYS}

\section{SOURCES}

The phyllosilicate (layered or sheet structured arrangement of the silicate tetrahedra) clay minerals, such as talc, montmorillonite, and bentonite, for example, constitute the groups of clays generally used to amend soils. Various clays are mined in every State except Rhode Island and Alaska (as of 1969). The materials mined include fresh and weathered shales and schist, alluvium, and loess. The resources are virtually inexhaustiblethey exceed several billion tons.

\section{MODE OF ACTION}

Size, ion exchange capacity, and surface area are properties of layered clay minerals that account for their usefulness as soil amendments. Average properties of specific clay minerals within the group vary considerably; therefore, some clay species are more effective as amendments than others. The following table gives an indication of the differences in properties of a few clay minerals in the group of layered clays:

\begin{tabular}{lccc}
\hline \multicolumn{1}{c}{ Clay mineral } & $\begin{array}{c}\text { Diameter, } \\
\mathrm{m} \times 10^{-\mathrm{e}}\end{array}$ & $\begin{array}{c}\text { Exchange } \\
\text { capacity, } \\
\mathrm{meq} / 100 \mathrm{~g}\end{array}$ & $\begin{array}{c}\text { Surface area, } \\
\mathrm{m}^{2} / 100 \mathrm{~g}\end{array}$ \\
\hline Montmorillonite & $\mathbf{0 . 0 1 - 1 . 0}$ & $80-150$ & $700-800$ \\
Illite & $.1-2.0$ & $10-40$ & $100-120$ \\
Kaolinite & $.1-5.0$ & $3-15$ & $5-20$ \\
Vermiculite & --- & $100-150$ & --- \\
\hline
\end{tabular}

\section{Clays-Continued}

As an example of the mode of action of clays, the incorporation of clay into a sandy soil affects the water relationships and the ability of the soil to retain fertilizer. The added clay changes the pore size distribution within the soil so that a greater proportion of the pores available to hold water are smaller in diameter; therefore, more energy is required to extract the water from the pores.

This water in smaller pores is not susceptible to drainage by gravity, requires a greater amount of energy for evaporation, and is available to plants. The interactions of the added clay and the existing sand and organic residues produce more stable structural aggregates which improve the physical condition (tilth) of the soil. Improved tilth reduces the susceptibility of the soil to wind and water erosion, aiding in soil and nutrient conservation. The addition of clay also enhances the ability of soils to hold nutrients in a form that is available for plant growth against the force of water movement which tends to leach or flush the nutrients from the soil.

\section{EXTENT OF USE}

The majority of mined clay minerals are used for nonagricultural purposes. The only important use of these minerals in plant culture is in the horticultural industry, where vermiculite is commonly a component of potting soil mixtures, or is used for soil improvement of golf greens and other nonagricultural sods. However, vast areas of clay soils are used for intensive agricultural crop production. The physical problems of the various clay soils are managed by different methods which vary with the geographical location and the kind of crops produced. In southern California where the clay soils are used for intensive vegetable production, for example, the physical difficulties of cultivation are overcome by energy expenditure. The clay clods are physically pulverized by large powerful implements and formed into a structure suitable for plant growth.

In eastern North Dakota and northwestern Minnesota, the clay soils are managed in such a manner that the freezing and thawing action during fall, winter, and spring accomplish the disintegration of clay clods into a form suitable for crop production. This example shows that different management techniques are employed in different environmental settings to overcome the same problem of compacted clays and points up the fact that farming practices, including the use of amendments, must not only be compatible with the physical character of the soil but must also consider the environmental setting as a whole. 
Clays - Continued

\section{POTENTIAL FOR USE}

The utilization of clay as a soil amendment for commercial production of food is in the experimental stages. Studies have shown that the addition of clay to sandy soils does, in fact, improve soil physical properties and increase yields. As an example, a study in West Bengal showed that 20 percent of the yield variance could be attributed to increased aggregate stability that resulted from the addition of bentonite and organic amendments to a sandy soil. However, the variance was not proportioned between the clay and the organics added; therefore, it is not possible from these data to determine the individual effect of the clay additive.

\section{ZEOLITES}

\section{SOURCES}

Zeolites (hydrated aluminosilicates) are tectosilicates; that is, the silicate tetrahedra $\left(\mathrm{SiO}_{4}\right)$ are arranged in a three-dimensional framework. Zeolites are associated with diverse geologic settings, ages, and lithologies, but most commercial exploration for bedded zeolites has occurred in old lake beds in the Southwestern U.S. Resources in this country are conservatively estimated at $\mathbf{1 0}$ trillion tons.

\section{MODE OF ACTION}

Particle size, surface area, and ion exchange capacity account for the usefulness of zeolites as soil amendments. These properties were discussed earlier under "Clays."

\section{EXTENT OF USE}

Zeolites have not been extensively used as soil amendments in commercial agriculture but are used to a limited extent in soil mixtures for horticultural uses. Reports of experiments with zeolites as soil amendments are virtually nonexistent in the U.S. literature; however, their effects on soil physical properties probably are very similar to those of clays.

\section{POTENTIAL FOR USE}

Present U.S. production of zeolites is only a few hundred tons per year. The resources available and the economics of mining seem favorable for potential expansion of the zeolite industry. Basic and applied research is needed to determine the actual value of zeolites as soil amendments and the economics of their utilization in commercial agriculture.

\section{VOLCANIC MATERIALS}

\section{SOURCES}

Volcanic materials include pumice, pumiceite, perlite, obsidian, and scoria. In chemical composition, pumice, pumiceite, perlite, and obsidian resemble basalt. In the U.S., volcanic materials are confined to the Western States, including Alaska and Hawaii, being absent from the Central and Eastern States except for the pumiceite deposits that occur in Kansas, Nebraska, and Oklahoma. Estimates of volcanic materials resources in the U.S. are 1-9 billion tons of mafic materials and 100-150 million tons of silicic materials.

\section{MODE OF ACTION}

The type of alteration of soil physical properties by the incorporation of volcanic materials depends largely on the particle size of the materials; that is, sand-size particles will assume the mode of action of sand, and clay-size particles the action of clays. Fresh volcanic materials are generally noncrystalline (amorphous) and are readily weathered to form various clay minerals.

The addition of these materials to soil would provide several micronutrient elements that are used by plants, the specific suite of elements varying with the composition of the ash. Fresh volcanic ash fallout from the Surtsey volcano in Iceland contained concentrations of fluorine that were toxic to sheep and cattle that grazed plants which grew in the ash. It is assumed that leaching will soon dissipate the toxic fluorine levels.

\section{EXTENT OF USE}

Perlite is used to a limited extent in horticultural operations as a component of soil mixtures; but we have not found references in American literature on the use of other volcanic materials as a soil amendment. Volcanic materials are used in situ for intensive agricultural production in some regions. The physical properties of volcanic soils are variable, depending largely on the age and composition of the volcanic material from which they were formed. For example, in some volcanic soils, the welding-together of particles may be sufficient to inhibit root penetration, however, in others the high degree of porosity may prevent adequate retention of water for satisfactory plant growth. 
Volcanic Materials - Continued

\section{POTENTIAL FOR USE}

Weathered volcanic deposits contain a suite of clay minerals, for example, vermiculite and bentonite, that have potential value as soil amendments. Their actual usefulness for improving the physical properties of soils has not been adequately demonstrated, and this, together with the economics of mining and transporting the materials, has not promoted their use in commercial food plant production.

\section{SAND}

\section{SOURCES}

Sand is defined as any rock or mineral within a specified range of particle sizes (2-0.05 mm, USDA system; $1 / 4-1 / 16$ in., ASTM system). Water and ice are the principal sorting and transportation agents responsible for the commercially important deposits, wind-blown sand comprising only a minor part of these deposits except on a very local scale. These deposits are distributed in all regions of the United States, in that river channels, flood plains, marine and lake environments, dunes, and glaciated terrain are source areas. The volume of potential resources is difficult to estimate, and the value is governed by complex economic factors. Shortages of sand are predicted for local areas in the near future because of land use priorities and the economics of production and transportation.

\section{MODE OF ACTION}

Incorporation of sand into a soil results mainly in alterations of physical properties of the soil. The surface area of sand particles per unit weight or volume precludes their usefulness in ion exchange reactions and as readily available sources of plant nutrients. However, exceptions are noted in sandsize particles of calcite, apatite, sylvite, and other soluble minerals. The addition of sand to clay soils changes the pore size distribution in the soils and a greater proportion of the pores are larger in diameter. This change will improve the air-water environment for plant roots, especially in soils that are seasonally too wet for satisfactory crop production. The implication here is that wet soils are "cold" during the seed germination time and only warm up slowly.

\section{EXTENT OF USE}

For mined sand, as for clays, nonagricultural uses predominate. Some mined sand is used in the horticultural industry for inclusion in soil mixtures. Extensive areas of sandy soils throughout the U.S.
Sand-Continued

are used for crop production and are valued for their ease of cultivation. Maintaining adequate moisture and nutrient retention are the greatest management problems in crop production on these soils.

\section{POTENTIAL FOR USE}

The use of sand-size materials as soil amendments has received very little experimental attention. A specific study, in which sand was incorporated into the plow zone (0-6 in. depth; $0-15.2 \mathrm{~cm}$ ) of a clay soil, demonstrated that the addition of sand decreased the amount of organic matter and phosphorus, improved tilth, and facilitated mechanical harvesting of the crop. The yield response varied with the crop grown but tended to remain unchanged or was decreased compared to the yield of the control crop plots. The potential appears to be very slight for the use of sand as an amendment to improve soil physical properties in large scale agricultural production. These properties can be modified equally as well by annual incorporation of crop residues as by the application of sand; moreover, plant residues generally are less expensive to use and at the same time provide plant nutrients that are lacking in sand.

\section{Organic Materials}

\section{PEAT}

\section{SOURCES}

Peat is an all-inclusive term used for geologic accumulations of plant material (excluding coal). Specific types of peat are recognized by their plant origin, degree of decomposition, ash content, and water-holding character. Peat deposits are delimited by the occurrence of a favorable climate, topography, and vegetation for their formation. The northeastern quarter of the U.S. (glaciated terrain), the Atlantic and Gulf coasts, the western mountains and coasts, and Alaska are source areas for various types of peat deposits. Potential resources of peat vary in magnitude by $10^{5}$ tons between certain States; for example, the potential resources of Delaware are estimated to be $10^{5}$ tons, contrasted with $10^{10}$ tons in Minnesota. Quantitative information is not available to estimate potential resources of various quality peats. The U.S. production of peat in 1970 was $1 / 2$ million tons. Of the total U.S. consumption, approximately $1 / 3$ was imported from Canada and Europe. The potential demand for peat in the U.S. is projected to be between 1.2 and 2.4 million tons in the year 2000 . 
Peat - Continued

\section{MODE OF ACTION}

Water-holding capacity, ion exchange capacity, and volume-weight ratio are properties of peat materials that account for their desirability as soil amendments. Each of these properties may vary depending on type of peat; for example, waterholding capacity for a highly decomposed peat may be $150 \%$ of its dry weight, but for Sphagnum peat may be $3,000 \%$. Ion exchange capacity of peat materials may range from 125 to 400 milliequivalents per $100 \mathrm{~g}$, the exchange capacity increasing with the degree of decomposition. Incorporation of peat into a mineral soil will markedly improve the physical condition of the soil. Applied to sand, it will increase water-holding and nutrient-retention capacity; in clay, it will increase water infiltration, make the soil more friable, and decrease the volume-weight ratio, thus enhancing root penetration.

\section{EXTENT OF USE}

The horticultural industry is the greatest user of mined peat for plant propagation in the U.S. Mined peat has not been used to an appreciable extent as a soil amendment in commercial agriculture, but agricultural uses of peat lands has been expanding because these lands are quite suitable for intensive vegetable production, forestry, and as grazing lands. Peat lands are especially well suited to crop production in northern areas where peat, when drained and cultivated, decomposes more slowly than in southern regions.

\section{POTENTIAL FOR USE}

Probably the greatest potential use for peat lands for agricultural production is their cultivation in situ. Mining, processing, and transportation costs, problems of distribution, and the demand for other uses of peat are some factors that limit its use as a soil amendment in commercial agriculture. Areal distribution and the properties of specific peat types need to be inventoried in order to realize the potential of the vast peat resources of the U.S.

\section{HUMATES}

\section{SOURCE}

Humates are dissolved or colloidal organic materials of plant and animal origin which have accumulated by precipitation or flocculation in certain physiochemical aqueous environments. Humate deposits have been identified and characterized in Florida along the Gulf Coast (Swanson and Palacas, 1965). Humates may also occur in coal deposits which have undergone weathering; therefore, the sources of
Humates-Continued

humates may be present over large geographic areas. Estimates of potential reserves of humates have not been published.

MODE OF ACTION

Humates have a character similar to some of the extracts of soil organic matter. In soil organic matter, these materials are the products of microbial action on organic residues. Mined humates, therefore, would serve to form stable soil aggregates by actions similar to those of native organic residues in soil. Increased aggregation and organic content of soils aids water infiltration, reduces dispersion and surface crusting, and provides more favorable airwater relations for plant growth.

\section{EXTENT OF USE}

We do not know of instances where mined humates have been used as soil amendments.

POTENTIAL FOR USE

Within the framework of economics of production and transportation, mined humates may serve as suitable soil amendments. They could potentially be used as a source for organic carriers in commercial fertilizers and would provide the added benefits of adding organic matter to soils.

\section{Miscellaneous Materials}

Many other materials have potential use as soil amendments, but they are not discussed here (except fly ash) because of their nongeologic nature, their treatment elsewhere in this report, the fact that their usage is principally nonagricultural (as in construction), or because of the limited information that is available. In principle, the miscellaneous amendments used to improve the physical properties of the soil will generally have (depending on their characteristics) the modes of action described for the materials already discussed. Their specific actions will depend on the particle size, surface area, and ion exchange capacity of the material. The function of physical amendments is to alter the pore-size distribution in the soil and to improve soil structure. Other benefits derived from altering the physical properties of soils are related to chemical, biological, and microbiological soil properties, and are not treated here. One material in this group, fly ash, is discussed because of the current interest in the use of coal as fuel for electrical energy production.

\section{FLY ASH}

(abstracted from Capp and Spencer, 1970)

Widespread use of the pulverized fuel burned by electric utilities has produced significant amounts of fly ash that have found relatively limited use. In the " $2 \frac{1}{2}$ 
Fly Ash-Continued

decades" since the end of World War II, an estimated 300 million tons of fly ash have been produced in the United States, of which only about 3\% has been utilized. The disposal of fly ash costs from $\$ 0.25$ to $\$ 2$ per ton, which creates an economic incentive to convert it from a liability to an asset.

Although most of the fly ash used has been in industrial processes, studies have been made of its value as a soil amendment in spoil bank reclamation, turf-soil beneficiation, and crop production. Some fly ashes have a high $\mathrm{pH}$, a higher content of some macronutrients and most micronutrients, and better moisture retention than many soils, and may at the same time improve the tilth of "heavy" soils.

\section{Use To Improve Soil Physical Properties}

As an amendment of physical properties, fly ash increases the water-holding properties of some soils and also the availability of this water to plants. In experiments that were conducted in West Virginia, fly-ash treated soils accumulated a reservoir of moisture from heavy spring rains, and this moisture continued to be available even during the summer dry period. In contrast, the control soils retained little moisture from spring rains; and during the dry period, the moisture held was not in the available range for plants during several weeks of the dry period. These plots were then fertilized with a 10-10-10 commercial fertilizer $(10 \% \mathrm{~N}-10 \% \mathrm{P}-10 \%$ $\mathrm{K}), 1,000 \mathrm{lb} / \mathrm{acre}(1,120 \mathrm{~kg} / \mathrm{ha})$, then seeded with grass or grass-legume mixtures. The fly-ash treated plots yielded 1.09 tons/acre (3.44 metric tons/ha), while the control plots gave no yield because of very poor plant survival after germination that resulted from poor physical condition of the soil.

Sintered fly-ash experiments on turf soil showed that the treated sods had higher water intake rates and total accumulated intake than the control sods. The accumulated intake tended to increase with the increase in volume percent of sintered fly ash added. Results of these field experiments indicated that this amendment is potentially valuable as a soil modifier, particularly to assist water infiltration on heavily used turf areas. However, the high temperature involved in sintering appears to inhibit the release of excessive amounts of certain micronutrients that could be present.

\section{Use To Improve Soil Chemical Properties}

Fly ash ordinarily does not contain sufficient macronutrient elements to be classified as a fertilizer material on ordinary agricultural soils. It is generally low in $\mathbf{P}$ and contains almost no $\mathrm{N}$. However, it may prove
Fly Ash-Continued

useful as a substitute for natural soil for revegetating spoil banks and similarly disturbed areas or to improve the fertility of very poor soils. Elemental abundances in fly ash were reported as follows:

\begin{tabular}{|c|c|c|}
\hline Element & Percent & $\begin{array}{c}\text { Approximate amount } \\
\text { lb/ton ash }\end{array}$ \\
\hline $\mathrm{Ca}$ & 1.00 & $20(10 \mathrm{~kg} /$ metric ton $)$ \\
\hline $\mathrm{Mg}$ & .36 & $6.7(3.3 \mathrm{~kg} /$ metric ton $)$ \\
\hline $\mathrm{K} \ldots \ldots \ldots$ & 1.74 & $35(17.6 \mathrm{~kg} /$ metric ton $)$ \\
\hline $\mathrm{P}$ & .13 & $2.7(1.3 \mathrm{~kg} /$ metric ton $)$ \\
\hline 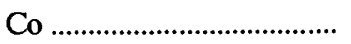 & .01 & $.2(0.1 \mathrm{~kg} /$ metric ton $)$ \\
\hline Mo & .01 & $.2(0.1 \mathrm{~kg} /$ metric ton $)$ \\
\hline В & .01 & $.2(0.1 \mathrm{~kg} /$ metric ton $)$ \\
\hline $\mathrm{Mn}$ & .02 & $.4(0.2 \mathrm{~kg} /$ metric ton $)$ \\
\hline $\mathrm{Al}$ & 14.01 & $283(142 \mathrm{~kg} /$ metric ton $)$ \\
\hline $\mathrm{Fe}$ & 9.94 & $200(100 \mathrm{~kg} /$ metric ton $)$ \\
\hline
\end{tabular}

The major problem in using some fly ash as a soil amendment is the concentrations of certain elements at levels that are toxic to plants. In British experiments, fly ash was found to contain amounts (15-30 ppm) of $B$ that are toxic to some plants. Because removal of the B was impractical, plants were tested for resistance to this toxicity. White sweet clover grew under the most toxic conditions, followed by white clover, red clover, and alfalfa. Rye grasses were very tolerant. Food plants of the beet and cabbage family were tolerant, and rye was the only cereal that was really tolerant. Oats, barley, peas, beans, and potatoes were intolerant.

\section{OTHER MATERIALS}

Some other miscellaneous materials that have been used as soil amendments follow:

Limestone

Gypsum

Calcined clay

Iron alum ("Flotal")

Animal manure

Sewage sludge

Wood residues, including redwood bark

Osmunda fiber

Peanut shells and other crop residues

Green manures

Ground-up rubber tires

Manufactured organic amendments ("Krilium," for example)

\section{REFERENCES CITED}

Allaway, W. H., 1968, Agronomic controls over the environmental cycling of trace elements: Advances in Agronomy, v. 20, p. 235-274. 
Buckman, H. O., and Brady, N. C., 1969, The nature and properties of soils ( 7 th ed.): New York, The Macmillan Co., 653 p.

Capp, J. P., and Spencer, J. D., 1970, Fly ash utilization, a summary of applications and technology: Information Circular 8483, U.S. Bureau of Mines, 72 p.

Connor, J. J., Shacklette, H. T., and others, 1975, Background geochemistry of some rocks, soils, plants, and vegetables in the United States: U.S. Geological Survey Professional Paper 574-F, 168 p.

Grey, D. C., and Jenson, M. L., 1972, Bacteriogenic sulfur in air pollution: Science, v. 177, no. 4054, p. 1099-1100.

Mortvedt, J. J., and Cunningham, H. G., 1971, Production, marketing, and use of other secondary and micronutrient fertilizers, in Olson, B. A., editor-in-chief, Fertilizer technology and use ( $2 \mathrm{~d}$ ed.): Madison, Wisconsin, Soil Science Society of America, Inc., 611 p.

Shacklette, H. T., and Boerngen, J. G., 1984, Element concentrations in soils and other surficial materials of the conterminous United States: U.S. Geological Survey Professional Paper 1270, 105 p.

Shacklette, H. T., Sauer, H. I., and Miesch, A. T., 1970, Geochemical environments and cardiovascular mortality rates in Georgia: U.S. Geological Survey Professional Paper 574-C, 39 p.Swanson, V. E., and Palacas, J. G., 1965, Humate in coastal sands of northwest Florida: U.S. Geological Survey Bulletin 1214-B, 29 p.

Thorne, C. E., 1930, The maintenance of soil fertility: New York, Orange Judd Publication Company, Inc., 332 p.

Tisdale, S. L., and Nelson, W. L., 1967, Soil fertility and fertilizers (2d ed.): New York, The Macmillan Co., 694 p.

Turekian, K. K., and Wedepohl, K. H., 1961, Distribution of the elements in some major units of the Earth's crust: Geological Society of America Bulletin, v. 72, p. 175-192.

\section{SELECTED REFERENCES}

Barth, R. C., Severson, R. C., and Weiler, G., 1987, Boron, in Williams, R. D., and Schuman, G. E., (editors), Reclaiming mine soils and overburden in the western United States; Analytical Parameters and Procedures: Ankeny, Iowa, Soil Conservation Society of America, $336 \mathrm{p}$.

Brobst, D. A., and Pratt, W. O., eds., 1974, U.S. mineral reserves: U.S. Geological Survey Professional Paper 820, 722 p.

Chapman, H. D., (ed.), 1966, Diagnostic criteria for plants and soils: Riverside, Calif., California University Division of Agricultural Science, 793 p.
Gardner, W. H., 1972, Use of synthetic soil conditioners in the 1950's and some implications to their further development: Ghent, Belgium, Mededelingen Fakulteit Landbouwwetenschappen State University, v. 37, no. 3, p. 1046-1061.

Gough, L. P., and Shacklette, H. T., 1979, Element concentrates toxic to plants, animals, and man: U.S. Geological Survey Bulletin 1466, 80 p.

International Potash Institute, 1970, Role of fertilization in the intensification of agricultural production; 9th Congress International Potash Institute, Antibes, 1970 report: Berne, Switzerland, International Potash Institute, 489 p.

Kabota-Pendias, Alena, and Pendias, Henryk, 1984, Trace elements in soils and plants: Boca Raton, Florida, CRC Press, Inc., 315 p.

Neuman, D. R., Schrack, J. L., and Gough, L. P., 1987, Copper and molybdenum, in Williams, R. D., and Schuman, G. E., eds., Reclaiming mine soils and overburden in the western United States; Analytical Parameters and Procedures: Ankeny, Iowa, Soil Conservation Society of America, 336 p.

Olson, B. A., editor-in-chief, 1971, Fertilizer technology and use (2d ed.): Madison, Wisconsin, Soil Science Society of America, Inc., $611 \mathrm{p}$.

Raup, D. B., (editor), 1977, Proceedings of the geology and food conference, with related U.S. Geological Survey Projects and a bibliography: U.S. Geological Survey Circular 768, 51 p.

Reeder, J. D., and Sabey, Burns, 1987, Nitrogen, in Williams, R. D., and Schuman, G. E., editors, Reclaiming mine soils and overburden in the western United States; Analytical Parameters and Procedures: Ankeny, Iowa, Soil Conservation Society of America, $336 \mathrm{p}$.

Safaya, N. M., McLean, J. E., and Halverson, G. A., 1987, Cadmium and zinc, in Williams, R. D., and Schuman, G. E., (editors), Reclaiming mine soils and overburden in the western United States; Analytical Parameters and Procedures: Ankeny, Iowa, Soil Conservation Society of America, $336 \mathrm{p}$.

Shacklette, H. T., 1980, Elements in fruits and vegetables from areas of commercial production in the conterminous United States: U.S. Geological Survey Professional Paper 1178, 149 p.

Shacklette, H. T., and Connor, J. J., 1973, Airborne chemical elements in Spanish moss: U.S. Geological Survey Professional Paper 574-E, 46 p.

Underwood, E. J., 1971, Trace elements in human and animal nutrition ( $3 \mathrm{~d}$ ed.): New York and London, Academic Press, 543 p. 
APPENDIXES 1-4 


\section{APPENDIX 1}

\section{Suggested Terminology For Soil Amendments}

The terms additive, admixture, amendment, conditioner, fertilizer, and stabilizer have been used to describe various types of soil modification. The lack of definitive guidelines for use of the terms in describing specific soil modification processes aimed at specific uses has led to confusion in terminology. Therefore, we propose some specific guidelines based on dictionary definitions and intended usages of the following terms:

\section{DICTIONARY DEFINITIONS}

Additive. To be added; of the nature of an addition; characterized by addition.

Admixture. Anything added; an alien element or ingredient.

Amendment. Act of amending, correction, or improvement.

Conditioner. A restrictive, limiting, or modifying circumstance or agent.

Fertilizer. Any material used to enrich the soil for crops, especially a commercial orchemical manure.

Stabilizer. Any compound which, when included with a material, decreases the ability of the material to decompose spontaneously.
The terms additive, admixture, and stabilizer are generally used in describing the modification of soil properties for engineering purposes. We propose that these terms not be used to describe the modification of soil properties for agricultural purposes.

The terms conditioner and amendment have the same general connotation. We propose that amendment be employed, rather than conditioner, to describe materials of geologic origin used in agronomic aspects of soil modification. "Conditioner" has been employed quite extensively in the agronomic literature for synthetic materials used in the modification of soil properties for agricultural purposes; therefore, the use of "conditioner" for geologic materials may lead to some confusion.

The remaining terms, amendment and fertilizer, should be used in agreement with their intended function and prefixed with descriptive words to further describe their mode of action. For example, if limestone is incorporated into the soil to specifically supply calcium for plant growth, it should be referred to as an inorganic fertilizer. If limestone is added to soil primarily to change the soil $\mathrm{pH}$, it should be classified as a chemical amendment; however, if used primarily to improve soil aggregation, it should be termed a physical amendment.

We suggest, therefore, limiting the employable terms to two-fertilizer and amendment. The rationale for this usage is to avoid confusion in use or interpretation and to simplify the terminology yet retain integrity of terms. The use of modifiers with these terms should make their intended meanings more clearly understood. 


\section{APPENDIX 2}

\begin{tabular}{|c|c|c|c|}
\hline $\begin{array}{l}\text { To convert } \\
\text { column } 1 \text { into } \\
\text { column } 2 \text {, } \\
\text { multiply by }\end{array}$ & Column 1 & Column 2 & $\begin{array}{l}\text { To convert } \\
\text { column } 2 \text { into } \\
\text { column } 1 \text {, } \\
\text { multiply by }\end{array}$ \\
\hline \multicolumn{4}{|c|}{ Length } \\
\hline 0.394 & centimeter, $\mathrm{cm}$ & inch, in. & 2.54 \\
\hline \multicolumn{4}{|c|}{ Area } \\
\hline 247.1 & kilometer ${ }^{2}, \mathrm{~km}^{2}$ & acre, acre & 0.00405 \\
\hline 2.471 & hectare, ha & acre, acre & 0.405 \\
\hline \multicolumn{4}{|c|}{ Volume } \\
\hline 0.0097 & 3 meter ${ }^{3} \mathrm{~m}^{3}$ & acre-inch & 102.8 \\
\hline 2.838 & hectoliter, hl & bushel, bu & 0.352 \\
\hline 0.0284 & liter, l & bushel, bu & 35.24 \\
\hline 1.057 & liter, 1 & quart (liquid) gt & 0.946 \\
\hline \multicolumn{4}{|c|}{ Mass } \\
\hline 1.102 & ton (metric) & ton (English) & 0.9072 \\
\hline 2.295 & kilogram, kg & pound, lb & 0.454 \\
\hline 0.035 & gram, $\mathrm{g}$ & ounce (avdp) oz & 28.35 \\
\hline \multicolumn{4}{|c|}{ Pressure } \\
\hline 14.50 & bar & $\mathrm{lb} / \mathrm{inch}^{2}, \mathrm{psi}$ & 0.06895 \\
\hline \multicolumn{4}{|c|}{ Yield or Rate } \\
\hline 0.446 & ton (metric)/ha & ton (English)/acre & 2.240 \\
\hline 2.4299 & $\mathrm{~kg} / \mathrm{ton}$ (metric) & 1b/ton (English) & 0.4115 \\
\hline 0.892 & $\mathrm{~kg} / \mathrm{ha}$ & lb/acre & 1.12 \\
\hline 0.892 & kg/ha-furrow-slice & lb/acre-furrow-slice & 1.12 \\
\hline 1.15 & $\mathrm{hl} / \mathrm{ha}$ & bu/acre & 0.87 \\
\hline
\end{tabular}

\section{APPENDIX 3}

\section{Common Plant Names Used In This Report, With Corresponding Scientific Names}

Common names, as used in this text, are listed alphabetically. Generally, only common names are given in the publications consulted in preparing this report. For most of these names, there is no doubt as to their proper corresponding scientific names, but a few are ambiguous as, for example, the citation of "cherry" without specifying whether sweet cherry (Prunus avium) or sour cherry (Prunus cerasus) was intended. In these cases, both scientific names are given. The common names used are those generally applied in the United States.

Alfalfa, Medicago sativa $\mathrm{L}$.

Apple, Pyrus malus L.

Asparagus, Asparagus officinalis $\mathbf{L}$.

Avocado, Persea gratissima Gaertn. f.

Banana, Musa paradisiaca var. sapientum Kuntze

Barley, Hordeum vulgare L.

Bean, Phaseolus vulgaris L.

Beet, Beta vulgaris L.

Big bluestem, Andropogon gerardi Vitman

Black gum, Nyssa sylvatica Marsh
Bluegrass, Poa pratensis L.

Buckbush, Symphoricarpos orbiculatus Moench

Cabbage, Brassica oleracea var. capitata $\mathrm{L}$.

Carrot, Daucus carota var. sativa DC.

Cauliflower, Brassica oleracea var. botrytis $\mathrm{L}$.

Cherry, Prunus cerasus L., Prunus avium L.

Clover, Trifolium pratense $\mathrm{L}$.

Corn, Zea mays $\mathbf{L}$.

Cotton, Gossypium hirsutum L.

Cowpea, Vigna sinensis Endl.

Date palm, Phoenix dactylifera $\mathrm{L}$.

Field corn, Zea mays var. indentata Bailey

Flax, Linum usitatissimum L.

Grape, Vitis labruscana Bailey, Vitis vinifera L.

Johnson grass, Sorghum halepense (L.) Pers.

Kelp, various species of marine Brown Algae,

Phaeophyta.

Kentucky bluegrass, Poa pratensis L.

Lima bean, Phaseolus limensis Macf.

Mesquite, Prosopis juliflora var. glandulosa Cockerell 
Mustard, Brassica nigra Koch

Oats, Avena sativa $\mathrm{L}$.

Onion, Allium cepa L.

Orange, Citrus sinensis Osbeck

Pea, Pisum sativum L.

Peach, Prunus persica Batsch.

Peanut, Arachis hypogaea L.

Pear, Pyrus communis L.

Pignut hickory, Carya cordiformis (Wang.) K. Koch

Pineapple, Ananas comosus (L.) Merr.

Plum, Prunus salicina Lindl., Prunus domestica L.

Potato, Solanum tuberosum L.

Radish, Raphanus sativus L.

Red cedar, Juniperus virginiana L.

Red clover, Trifolium pratense $\mathrm{L}$.

Red maple, Acer rubrum L.

Red Mexican beans, Phaseolus vulgaris $\mathrm{L}$.

Rice, Oryza sativa L.

Rye, Secale cereale $\mathrm{L}$.

Ryegrass, Lolium perenne L., Lolium multiflorum Lam.
Sassafras, Sassafras albidum (Nutt.) Nees

Seaweed, various marine Brown Algae (Phaeophyta) and

Red Algae (Rhodophyta)

Shortleaf pine, Pinus echinata Mill.

Snap bean, Phaseolus vulgaris $\mathrm{L}$.

Sorghum, Sorghum vulgare L. (several subspecies)

Soybean, Glycine max Merr.

Spanish moss, Tillandsia usneoides $\mathrm{L}$.

Squash, Cucurbita maxima Duch., Cucurbita moschata Duch.

Sugar beet, Beta vulgaris L.

Sweet pepper, Capsicum frutescens var. grossum Bailey

Tobacco, Nicotiana tabacum $\mathbf{L}$.

Tomato, Lycopersicum esculentum Mill.

Turnip, Brassica napus L.

Water hyacinth, Eichornia crassipes (Mart.) Solms Western wheatgrass, Agropyron smithii Rydb.

Wheat, Triticum aestivum $\mathrm{L}$.

White clover, Trifolium repens $\mathrm{L}$.

White oak, Quercus alba $\mathrm{L}$.

White sweet clover, Melilotus alba Desr.

Willow oak, Quercus phellos L.

\section{APPENDIX 4}

\section{Glossary of Selected Terms Used in This Report}

Absorption. The active intake and incorporation of ions into plant cells from soil by ion exchange, mass flow, or contact exchange.

Acid soil. See $\mathrm{pH}$.

Acre-foot. The volume of water required to cover 1 acre $(0.405 \mathrm{ha})$ to a 1 -foot $(15.2 \mathrm{~cm})$ depth $(43,560$ cubic feet or 1,233 cubic metres).

Acre-furrow-slice. The amount of soil material contained within 1 acre ( 0.405 ha) to a depth of 6 inches $(15.2 \mathrm{~cm})$, generally considered to weigh $2,000,000$ pounds $(908,000 \mathrm{~kg})$.

Activity. The effective concentration of an ion or molecule in solution.

Adsorption. An accumulation of ions on a solid, caused by ion exchange or other reactions.

Aerobic. A respiration process occurring only in the presence of free oxygen.

Alkaline soil. $\quad$ See $\mathrm{pH}$.

Anaerobic. A respiration process occurring only in the absence of free oxygen.

Anion. A negatively charged ion.

Annual plants. Plants which complete their life cycle from seed to new seed in 1 year or one season of growth, then die.
Available nutrient. A nutrient which is not fixed or insoluble, but which can be taken up and used for plant growth.

Browse plants. Woody plants (shrubs or low trees) whose leaves and young stems are eaten in the field by animals.

Calcined. Having been made powdery by the action of heat; fritted.

Cation. A positively charged ion.

Chelates. (Name derived from "claw-like") Organic substances that act as ligands (see EDTA) with many coordination groups.

Chloroplast. A chlorophyll-containing body within a plant cell.

Chlorosis. A symptom of nutrient imbalance within a plant caused by chemical insufficiency or excess or by pathogenic organisms, expressed as yellowing of tissue that formerly was green.

Citric acid cycle. Biochemical pathways for the synthesis of cell material and for degradation of carbohydrates to gain energy.

Colloid. A material with a particle size larger than that of a substance in solution, generally from 0.001 to 0.1 micrometer in diameter. 
Contact exchange. Ion exchange between the external membrane of plant roots and soil colloids by direct contact.

Crystal. A solid body with a shape that reflects the regular internal arrangement of constituent atoms or ions.

Deficiency. The absence or insufficiency of some material necessary for normal growth and function of an organism.

Denitrification. The biochemical reduction of nitrate or nitrite to gaseous nitrogen either as molecular nitrogen or as an oxide of nitrogen.

Dissociation. The reversible decomposition of a complex substance into simple constituents.

EDTA. Abbreviation for ethylene-diamine tetracetic acid, an organic substance that acts as a ligand (that is, can form coordination complexes with metal ions).

Electron carrier. The cell material (for example, cytochrome) or molecules within the cell that are responsible for energy transfer.

Electron flow. As used in this report, a biochemical mechanism for transferring energy.

Enzyme. An organic catalyst produced by living cells.

Epiphyte. A plant that grows upon another plant, but without having physical connections to, or nutritional dependence on, the host plant.

Exchange capacity. The total ionic charge of the adsorption complex that is active in the adsorption of ions in soil.

Fly ash. A furnace residue produced when pulverized coal is burned in an electric power generating or other industrial plant.

Foliar application. The process of dusting or spraying plant leaves with fertilizers or pesticides.

Forage plants. Herbaceous plants eaten by animals in the field, in contrast to harvested plants used for animal feed.

Friable. A term pertaining to soil consistency, indicating that the soil is easily crumbled.

Frit. To prepare by heat, to fuse partly; frits, the material so prepared.

Geometric mean. The $n$th root of the product of $n$ numbers; the antilog of the sum of the logarithms of $n$ numbers divided by $n$. The geometric mean is useful in describing central tendency if the values are lognormally, or approximately log-normally, distributed. This distribution is generally true for minor element values for soil and plant materials.

Heavy soil. A soil with a high resistance to mechanical tillage.

Ion. An electrically charged atom or group of atoms. Ionize. The process of ion formation.

Lattice. Atoms or ions having ordered geometric arrangement within a crystal.
Leaching. The removal of soluble constituents from soil by the action of percolating water.

Leaf stalk. Petiole; that part of a leaf which connects the blade to the stem.

Light soil. A soil with a low resistance to mechanical tillage.

Lime. Any compound or mixture of compounds in which calcium is the principal component; specifically, materials of this nature used on agricultural soils.

Macroelement. An element essential for organisms that is required in large amounts; macronutrient; major element.

Microelement. An element essential for organisms that is required only in very small amounts; micronutrient; trace element.

Monoculture. A system of agriculture in which the same kind of crop is grown in a field in successive years, sometimes expressed as continuous cultivation, such as "continuous corn." Contrasts with "crop rotation." See "Rotation (crop)."

Morphological symptoms. Visible indications, expressed as changes in the form or shape of plant organs, of internal biological changes such as those produced by disease or chemical imbalance.

Muck. An organic soil composed of plant residues that are fairly well decomposed and having a relatively large content of mineral matter.

Neutral soil. See $\mathrm{pH}$.

Nitrification. The biochemical oxidation of ammonium to nitrate.

Osmotic pressure. The pressure developed within a cell in which the concentration of dissolved substances is greater within, than outside, the cell.

Osmunda fibers. - Coarse roots and rhizomes of certain large ferns, notably Osmunda cinnamomea and Osmunda regalis, used as potting media for certain plants or as a soil amendment.

Oxidation-reduction reactions. See Redox Potential.

Parenchyma. Large thin-walled isodiametric cells of plants.

Parts Per Million (ppm). Weight of a soluble substance divided by weight of solution times one million.

Peat. An organic soil composed of plant residues in various stages of decomposition, with little or no mineral material present.

Percent. Weight units of a substance per one hundred equivalent weight units.

Perennial plants. Plants which live for several years, usually not producing seed the first year.

pH. A logarithmic scale ranging from 1 to 14 , commonly used to express the degree of acidity or alkalinity. A pH of 1 is strongly acid and a pH of 14 is strongly alkaline; whereas, a $\mathrm{pH}$ of 7 is neutral (neither acid nor alkaline). 
Phosphorylation. The act or process of converting into a compound of phosphorus; specifically, the action of a group of enzymes in catalyzing reactions involving orthophosphate within a cell.

Plant cell sap. The liquid constituents of plant cells, composed of water and various dissolved organic and inorganic materials.

Plant residue. As applied to agriculture, the unharvested parts of crop plants that remain in the field.

Plant toxicity. The property of having poisonous effects on plants.

Precipitation. As used in this report, the separation of a substance from a solution so that the substance is in a solid form.

Primary minerals. The unweathered minerals of rock particles in soil, such as feldspars and micas.

Redox potential. The potential of a material, compared to other materials, to release electrons (oxidation) or to receive electrons (reduction), commonly measured in millivolts and expresed as Eh.

Rotation (crop). The practice of growing different crops in recurring succession on the same plot of land.

Scientific name. A compound name consisting of a genus and a species name written in the Latin language that is assigned to each recognized and described kind of organism. Variants in species characteristics may be designated as subspecies (populations discrete spatially), variety (isolated or random variations within a population), or cultivar (variations arising in cultivation). In formal writing, the name or abbreviated name of the author or authors of the scientific name follow the last epithet of the organism's name.

Secondary minerals. The weathered products, such as clays, of primary minerals.

Soil aeration. The process in which soil air is exchanged for atmospheric air. The volume and continuity of pores in the soil determine the aeration rate.

Soil drainage. The mechanism of water removal from soil; the relative degree of water retention by different soils.

Soil fixation. The conversion of an available or soluble substance in soil to a relatively insoluble or unavailable form.

Soil flocculation. The union of soil particles to form loose aggregates.
Soil horizon. A layer of soil horizontal to the Earth's surface having characteristics that distinguish it from soil layers both above and below it.

Soil permeability. The ease with which materials penetrate or pass through a bulk mass of soil.

Soil solution. The aqueous part of the soil consisting of soluble materials and ions dissociated from soil particles.

Soil submergence. Refers to a process in which a soil is waterlogged for significant periods of time.

Soil texture. The relative proportions of different sized particles in an amount of soil material.

Soluble. Capable of being dissolved.

Synergistic. A type of reaction in which two substances reinforce the separate effects produced by each or which, in combination, produce new effects.

Tailings. Mineral refuse from ore milling operations, usually deposited as small particles from suspension in water.

Tilth. The physical condition of soil as related to its ease of tillage, fitness as a seedbed, and its resistance to seedling emergence and root penetration.

Tissue analysis. Analysis of the chemical constituents of plant tissue.

Ton, English. A unit of weight equaling 2,240 pounds, also referred to as a "long ton."

Ton, metric. A unit of weight equaling 1,000 kilograms.

Translocation. The movement of dissolved materials in cell sap from one plant organ or tissue to another, as the movement of sugar from leaves to stem.

Turf. The low dense sod of grassland, comprising the above-ground parts and upper roots and rhizomes of plants, with attached soil particles.

Unavailable nutrient. See Soil Fixation.

Valence. The relative combining capacity of an atom or molecule compared to that of the standard hydrogen atom.

Vascular plants. Plants having specialized conducting tissue through which water, mineral salts, and food move.

Volatilization. The conversion of a solid or a liquid into a gas or vapor.

Woody plants. Plants that have pronounced development of wood (xylem) in their stems; usually applied to trees, shrubs, and certain vines. 